Historic, Archive Document

Do not assume content reflects current scientific knowledge, policies, or practices. 



\section{Sending Orders}

Please use order sheet which you find in this book; carefully filling out all blank spaces at top, giving shipping directions and write your name and address very plainly. Care in this way saves lots of trouble and annoyance both to yourself and us.

Free-We make no charge for boxing, packing or drayage on retail orders.

Packing-Our facilities for packing are unsurpassed, and we lay great stress on thorough packing, believing it to be the all-important step. Trees poorly packed are often worse than valueless when they reach the planter. Our stock is all packed under cover. Our packing sheds are reached from the storage cellars without going outside.

No Substituting-We send you the variety of tree or plant you order, or return your money, unless you advise otherwise. Please state if we will be allowed to put in other similar varieties in case we are out of the one you order.

Shipping. Location-Our shipping facilities are good, being located on the Chicago, Milwaukee \& St. Paul, the Chicago \& North-Western and the Great Northern railways, and we have the American, the United States and the Great Northern Express companies at this point.

Important-Address all letters to Whiting's Nurseries or Geo. H. Whiting. Make all drafts and money orders payable to Geo. H. Whiting. Remember, we cannot accept rrivate checks without allowance is made for cost of exchange.

Remember-That prices listed herein are for the quantities specified. That is, less than the amount quoted will be charged at the next higher rate.

\section{No Credit}

Do not ask us to give you credit. We have found by long experience that a catalogue trade cannot be successfully conducted in any other way than for cash before shipment of goods. I have adopted the cash system and must use everyone alike, no matter whether you are worth 1 cent or $\$ 1,000,000$.

Discounts-On all cash orders amounting to $\$ 10$, we allow a discount of 1 per cent, or 10 cents; on $\$ 20,2$ per cent, or 40 cents; on $\$ 30,3$ per cent, or 90 cents; on $\$ 40,4$ per cent, or $\$ 1.60$; on $\$ 50,5$ per cent, or $\$ 2.50$; on $\$ 60,6$ per cent, or $\$ 3.60$; on $\$ 70,7$ per cent, or $\$ 4.90$; on $\$ 80,8$ per cent, or $\$ 6.40$; on $\$ 90,9$ per cent, or $\$ 8.10$; on $\$ 100,10$ per cent, or $\$ 10$; that is $\$ 100$ worth of stock at catalogue prices will cost you only $\$ 90$ if cash accompanies the order. This is well worth looking after, and makes prices very low for strictly first-class stock.

Notice our complete general stock all through the list, and especially shade trees, all sizes transplanted evergreens and hardy ornamental shrubs. 


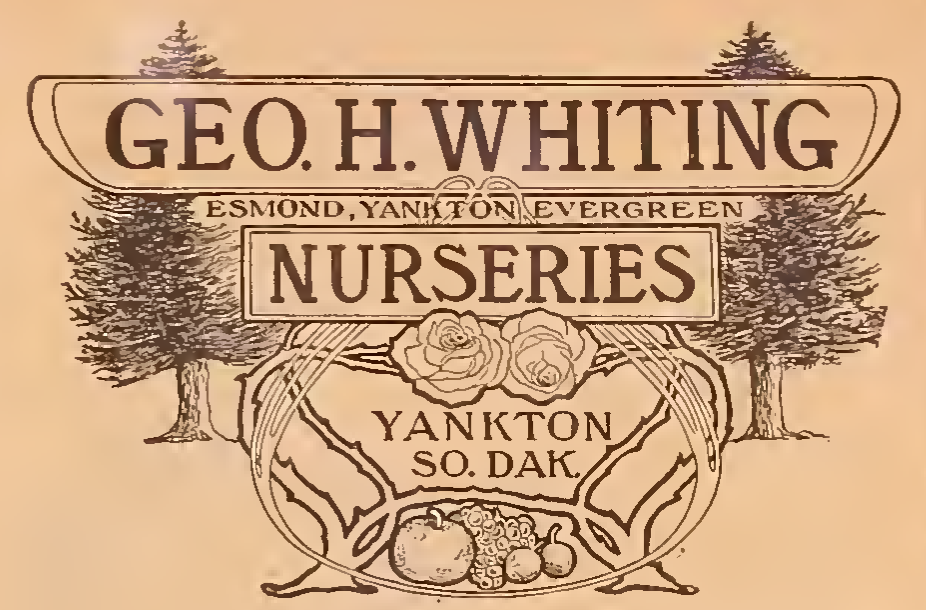

\section{ORDER SHEET}

Shin to Express ol Freight Ofrice

Enclosed find Remittance in (Draft, Cash, Ex. Order, Stamps) to the amount of $\$$

VICR IMPORTANT-Always write your Name and Adress vety plainly: by so doing you will save much troubie and tine mossibility of delay and mistakes in filling your order. I will not be responsible for money lost if sent in an ordinary ietter. I cunnot accept private checks unless aliowance is made to cover exchange. 1 or 2 cent stamps accepted in sums of \$2.00 or ioss.

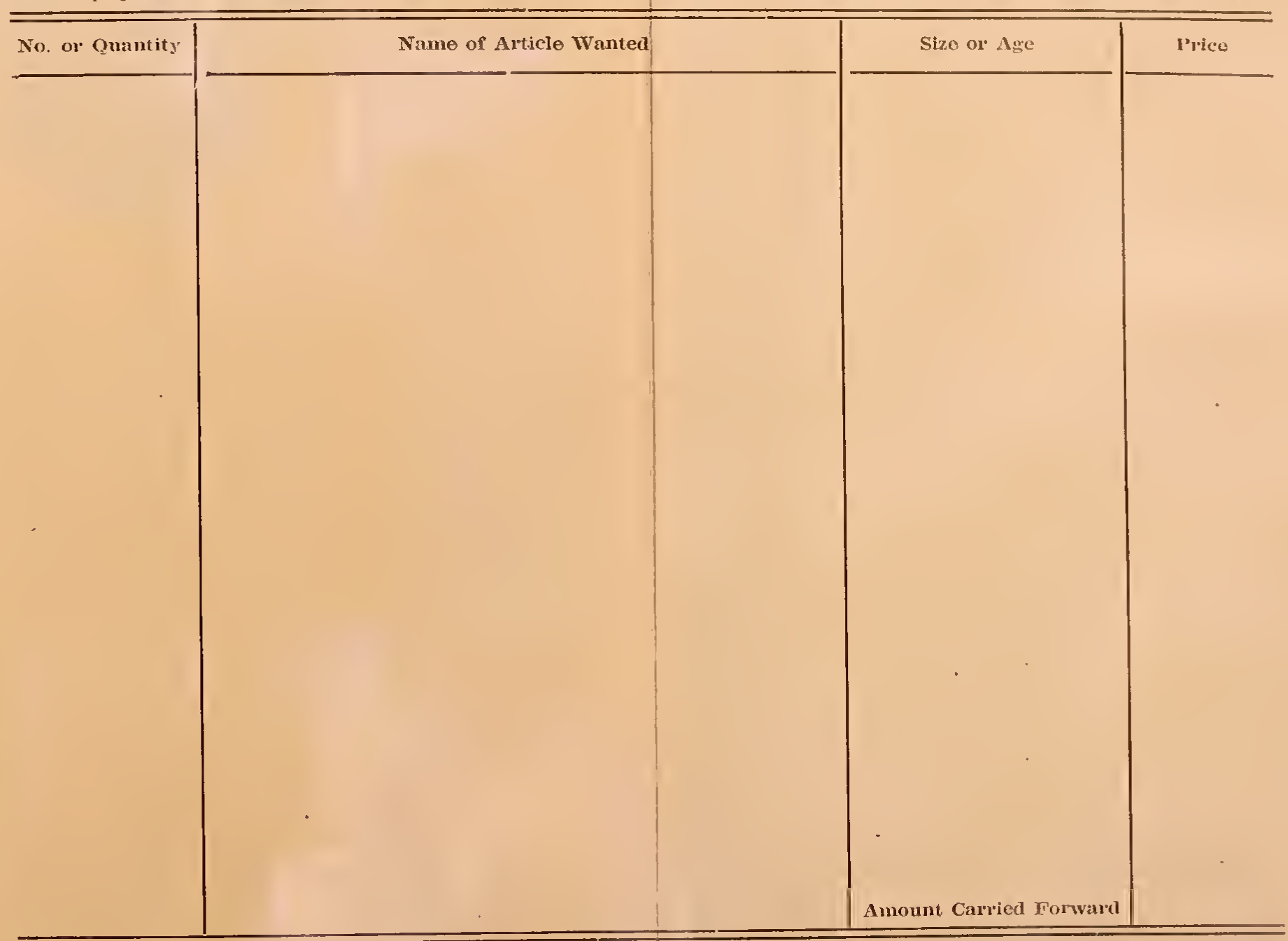

Be sure to address yolur orders PLAINLY to

\section{Geo. H. Whiting's $\underset{\text { Esmond, Yankton }}{\text { Evergeen }}$ Nurseries, Yankton, South Dakota (OVER)}




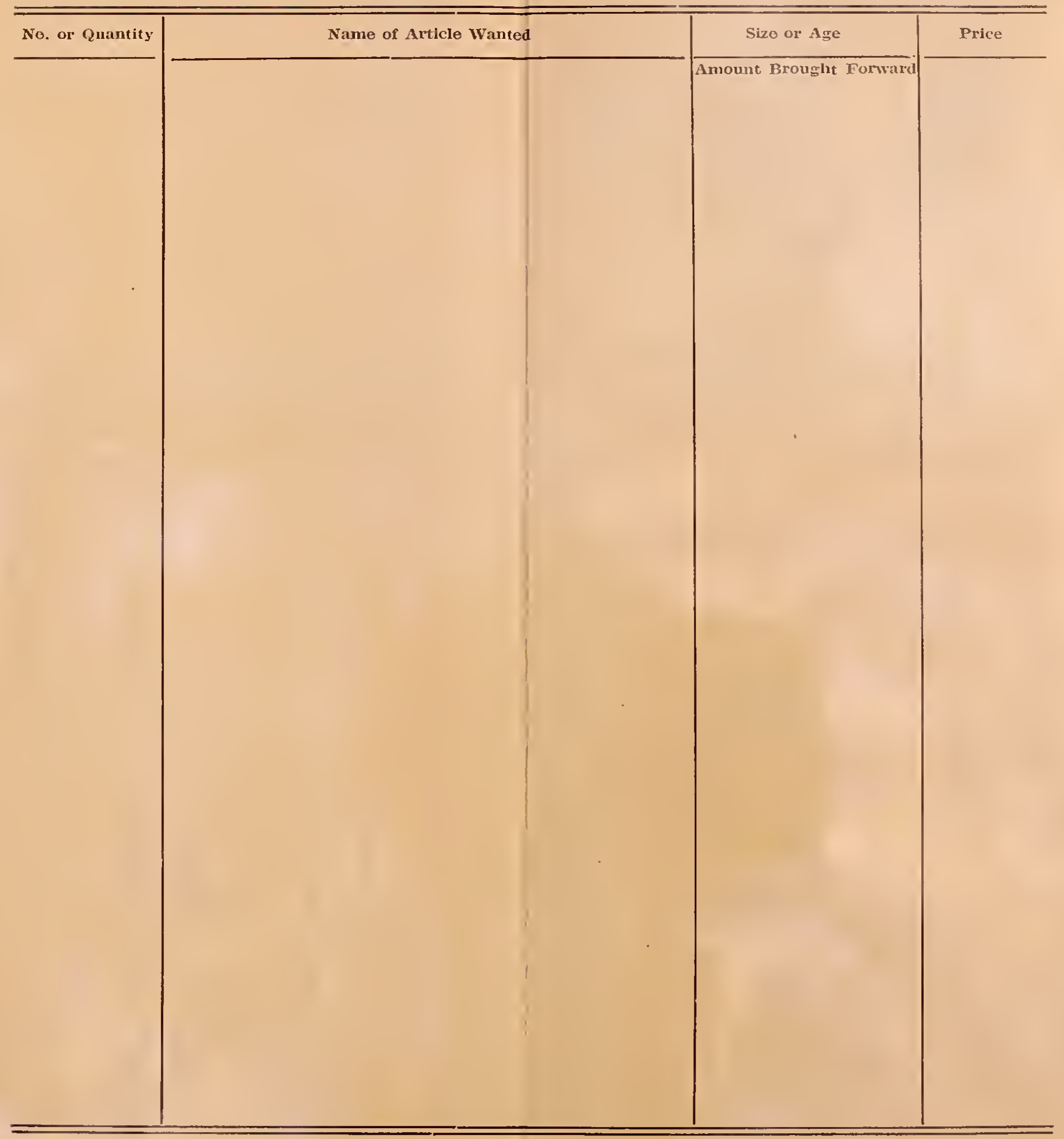

Be sure to address your orders PLAINLY to

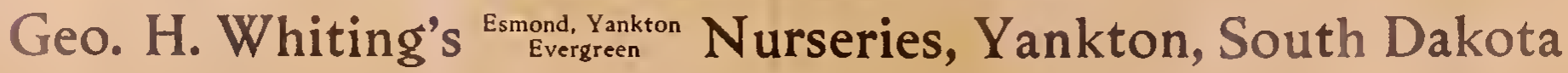
(OVER) 


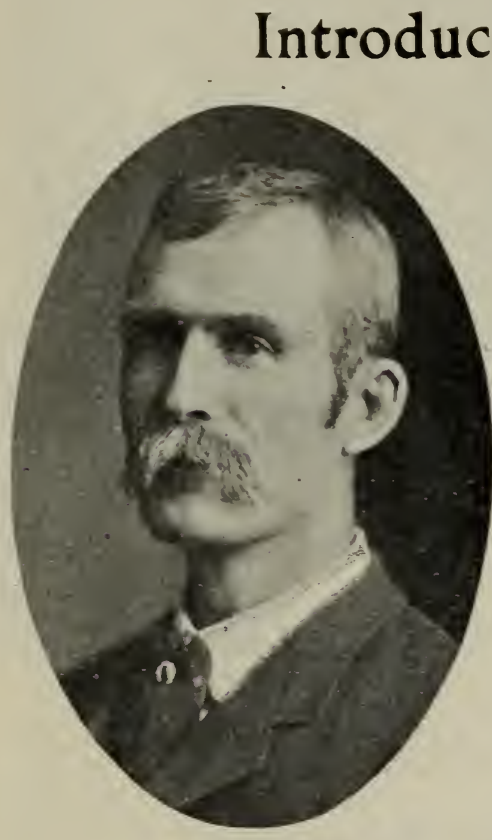

For the twenty-third time in my career as a nurseryman and fruitgrower, it gives me great pleasure to extend my annual greeting to a large army of friends and patrons, which, I am pleased to say, is rapidly increasing in numbers and at such a rapid rate that we found it absolutely impossible the past spring to take care of the orders as fast as we ought and would like to have done. The season was a hard one for the nurserymen, as the frost came out of the ground very late to begin the digging of trees, and when it did thaw out, the season advanced so rapidly that it was a very short one, which made it hard to handle about twice as many goods as in any previous season. Our customers in many cases became impatient because the goods did not reach them soon enough. To these I wish to say that I want to make good any losses they have met with on account of any unreasonable delays in filling orders. I hope and trust that we will be able to take care of them this year much more promptly than we did last, as we are in much better shape in many respects for handling goods, and also have a much larger and more complete stock than in any previous sear. Our nursery stock and farm at Yankton, S. D., is very materially improved, and the Bayfield, Wis., branch has been increased in acreage to 1,023 acres. Five acres are already planted to orchard, and a clearing made for a much larger planting the coming spring.

In conclusion, I want to say that we always have the interests of our customers at heart, and want to do the very best we can to make them succeed.

With best wishes, I am at your service.

GEO. H. WHITING, Proprietor Whiting Nurseries, Yankton, So. Dak. 


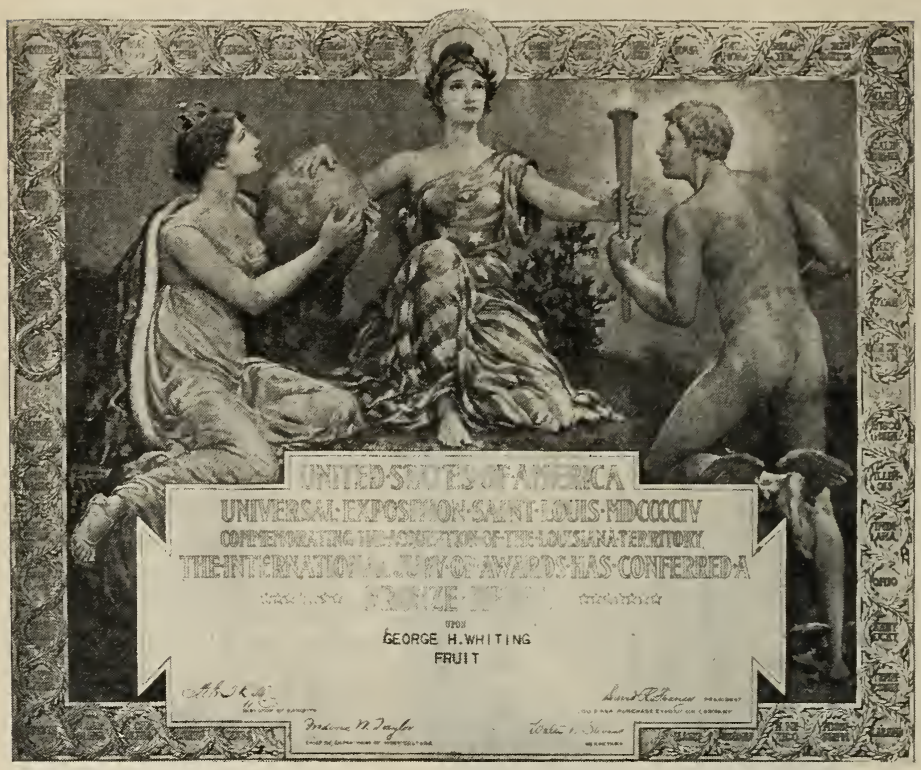

The above represents diploma or award conferred upon me for fruits exhibited at the Louisiana Purchase Exposition held at St. Louis in 1904.

\section{General Remarks}

Our shipping season usually begins about March 15th, or as soon as the weather is warm enough so that there will be no danger of freezing in transit. We have stock enough in our storage cellar, so that we can fill most orders at any time that the weather will permit of safe shipment, except such stock as evergreens, strawberry plants, some of the bulbs, and the very large sized shade trees that cannot be easily stored.

It is desired that you read this catalogue over carefully, and get what information you can, kut if there is anything else you wish to know in our line, write us, and we will try to inform you, and will take pleasure in doing you all of the good we can.

If you want anything in our line that you do not find listed here, ask us about it. We have many things that we do not have in sufficient quantities to pay for listing; „n short, we can supply trees from the smallest, tiniest seedlings to almost the size of a saw-log, and will be pleased to figure with you on your needs, large or small. Will give the same careful attention to small orders that we do to carload lots.

Varieties-Our list of varieties, while not large, we believe to be comprised wholly of valuable sorts for the Northwest. If you are in doubt as to the adaptability of a variety for your section, write us. With our experience of twenty-seven years in the Dakotas, we can surely assist you in making up your list of varieties. 


\section{Hints on Handling, Planting and Care}

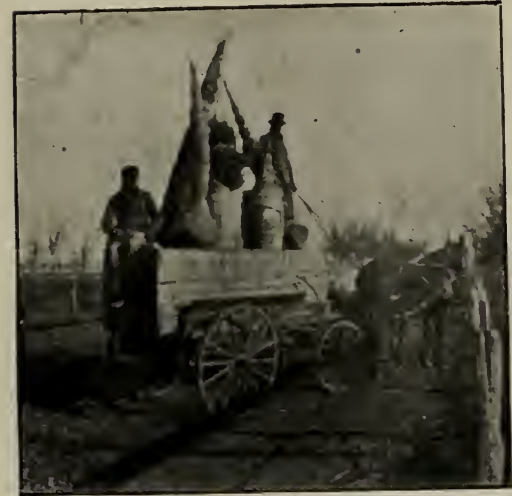

Care When Received -When trees or plants are received from the nursery, give them your attention at once. Do not let them lie around and dry out, but plant at once or bury the roots in cool, moist earth in a shady place until ready to plant. By taking a few precautions at this time, you can make a success of what would, by a little recklessness, have been a failure.

Planting-First, see that the ground is thoroughly and deeply plowed and finely pulverized; then dig a hole large enough to receive the roots in a natural position without bending or cramping them. See that all roots are cut off smoothly at the ends where they are bruised or mutilated, and shorten in the branches, and reduce the amount of top to compare with the loss of roots, usually one-fourth to onehalf, cutting mostly from the side branches so as to injure the main leader as little as possible. Now, see that the fine mellow earth is worked in around and between the roots, and firmly packed so that the tree will not be moved to and fro by every little breeze that passes. Also, remember that the roots cannot get hold of anything to start growth or subsist on unless they are firmly embedded in the soil; there is nothing better than good, rich, mellow soil. If mulch or litter is to be used, let it be on the surface and not in direct contact $\pi:$ th the roots.

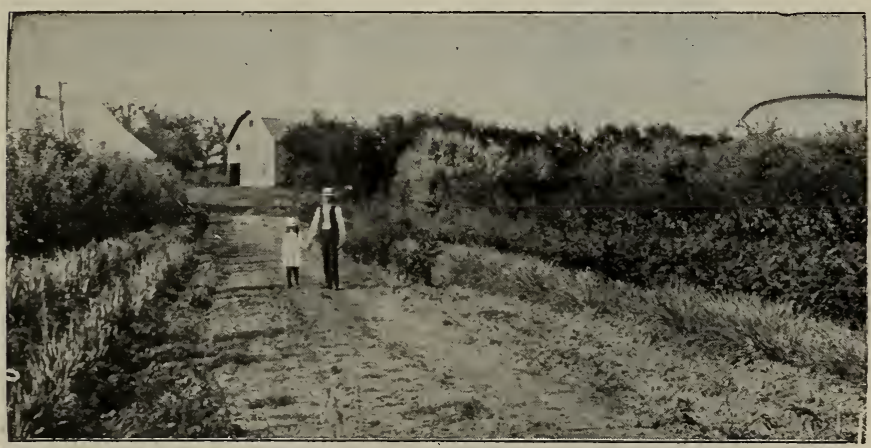

After Care-After planting is done see that the surface soil around the tree (for a good distance) is not allowed to become baked and hard. It should be stirred after every rain or watering, as soon as the water soaks away and the soil is in a good workable condition.

Remember that thorough cultivation is important in a dry climate. In fact, it is imperative to insure success. What farmer would expect to raise a good crop of corn or a garden without cultivation? If you do not intend to take care of what you plant, "better not plant." It will not pay you, nor will it pay us to sell to you; but we do love to sell to the careful, thorough planter. 


\section{Distances Apart to Plant}

The distances recommended here are for this section only. In other localities it may be advisable to change them.

No. of Trees or Plants per Acre

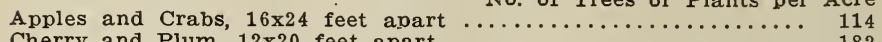
Cherry and Plum, $12 \times 20$ feet apart ..................... 182 Currants and Gooseberries, $4 \times 8$ feet apart ................. 1,360

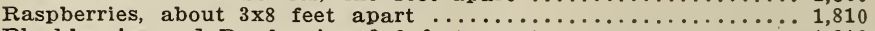

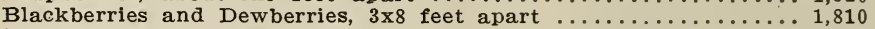

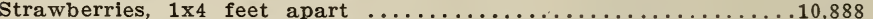

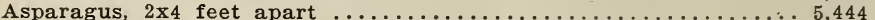

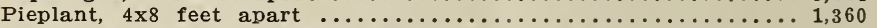
Deciduous Trees or Evergreens for shelter belts, $4 \times 12$ feet....... 940

\section{Number of Trees to the Acre at Various Distances}

\begin{tabular}{|c|c|c|c|}
\hline Feet & & part & Trees \\
\hline $11 / 2 x$ & 3 & $\ldots \ldots \ldots$ & 9,680 \\
\hline $21 / 2 x$ & 4 & $\ldots \ldots \ldots \ldots \ldots \ldots$ & 7,260 \\
\hline $3 x$ & 3 & $\ldots \ldots \ldots \ldots \ldots \ldots \ldots$ & 4,840 \\
\hline $3 x$ & 4 & $\ldots \ldots \ldots$ & 3,630 \\
\hline $4 \mathrm{x}$ & 4 & 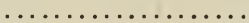 & 2,722 \\
\hline $3 x$ & 5 & & 2,904 \\
\hline $3 \times 6$ & & es & 2,420 \\
\hline $4 x$ & 5 & $\ldots \ldots$ & 2,160 \\
\hline $4 x$ & 6 & $\ldots \ldots \ldots \ldots \ldots$ & 1,815 \\
\hline $5 x$ & 5 & $\ldots \ldots \ldots \ldots \ldots$ & 1,042 \\
\hline $6 \mathrm{x}$ & 6 & $\ldots \ldots \ldots$ & 1,210 \\
\hline $6 \mathrm{x}$ & 8 & & 905 \\
\hline $8 x$ & & $\ldots$ & 680 \\
\hline $10 \times 1$ & & $\ldots \ldots \ldots \ldots$ & 435 \\
\hline
\end{tabular}

\begin{tabular}{|c|c|c|}
\hline \multicolumn{3}{|c|}{ Feet Apart } \\
\hline $10 \times 12$ & $\ldots$ & 363 \\
\hline $11 \times 11$ & $\cdots$ & 302 \\
\hline 15 & $\ldots \ldots \ldots \ldots$ & \\
\hline & $\ldots \ldots \ldots \ldots$ & \\
\hline 1 & $\ldots \ldots \ldots \ldots$ & \\
\hline & $\ldots \ldots \ldots \ldots$ & \\
\hline $18 \mathrm{x}$ & $\ldots \ldots \ldots \ldots \ldots \ldots$ & \\
\hline & $\ldots \ldots \ldots \ldots \ldots \ldots$ & \\
\hline & $\ldots \ldots \ldots \ldots$ & \\
\hline & $\ldots \ldots \ldots \ldots$ & \\
\hline 20 & $\ldots \ldots \ldots \ldots$ & \\
\hline 2 & $\ldots \ldots \ldots \ldots \ldots$ & \\
\hline $25 \times 30$ & 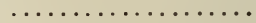 & \\
\hline $30 \times 30$ & $\ldots \ldots \ldots \ldots \ldots \ldots \ldots$ & \\
\hline
\end{tabular}

Rule-Multiply the distance between the rows by the distance. the plants are apart in the rows, and the product will be the number of square feet for each plant or hill, by which divide the number of feet in one acre $(43,560)$, and it will give the number of plants or trees to the acre.

\section{Fruit Department}

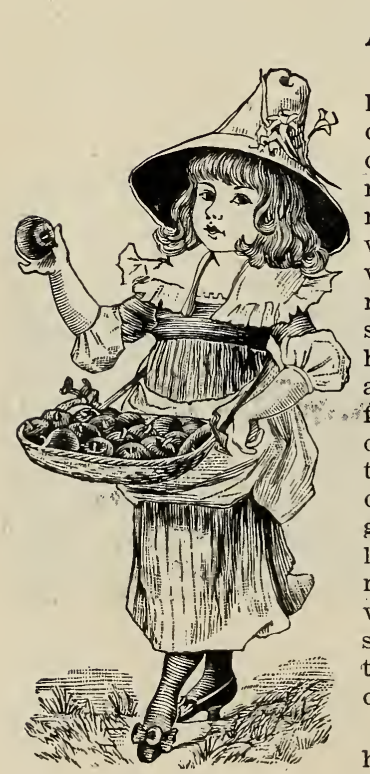

\section{APPLES}

Location of Orchards-While the higher elevations are considered best on account of early and late frosts, don't forget that in the Dakotas we must guard against drouth. We must plant on land not too dry, with northerly slopes and south wind-breaks, if practicable; then we must arrange in some way to conserve and utilize what moisture we have so that we will keep our trees alive and thrifty. Give the trees the full. supply by cultivation or mulch, or better still, by cultivating during the growing season sufficient to keep down all vegetation and keep the ground mellow, and then mulch lightly around the tree at the beginning of the winter, continving again with the cultivation the following summer. Repeat this each year until trees reach the bearing age, when cultivation should cease.

Wind-Breaks-It is not best to have too dense a wind-break around the orchard, but give a little air drainage. It is most important to have the shelter on the south and west sides. Do not plant wind-break trees too near the orchard to sap and shade the ground. Remember, the roots extend as far as the height of the tree or farther.

Form for Tree-There are advantages in both the low and the high-headed trees. The high-headed tree is easier to get around with a team without breaking or splitting the 
limbs. It is, also, more subject to being toppled over by the wind and to get sun-scalded, than the low-headed tree. We are inclined to think the low-headed tree is the better and longer-lived, but would have the trunk or body high enough (about $2 \frac{1}{2}$ feet) to keep the limbs off the ground. Bear in mind that the trunk of a tree does not increase in length as it grows older, as some suppose. That is, a tree that has limbs two feet from the ground when planted, these same limbs will never be any higher.

Do not let the tree throw up water-sprouts continually from near the ground, thereby robbing the main tree. We usually train our nursery trees to a pretty good height, as it is hard to make a high-headed tree out of a low one without cutting large limbs (which is injurious), but it is very easy to get the head lower by allowing them to start new limbs lower down, which they will readily do. Avoid cutting large limbs, as much as possible, but attend to shaping the tree while the limbs are small.

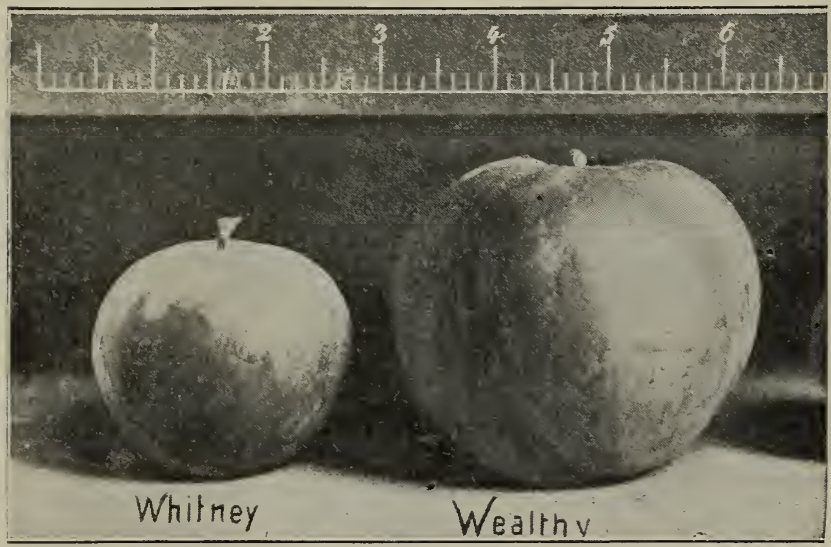

Distances Apart-I would plant apple trees 15 to 16 feet apart in the row, with the rows 20 to 24 feet apart, and always give apple trees thorough and frequent cultivation when trees are young, keeping down all weeds, and keep surface soil loose and mellow, at least, until they come to the bearing size.

How Our Apple Trees Are Made-We make the pieceroot graft, which is made with a 5 to 6 -inch scion and a 2 to 3 -inch root. We believe this to be the best tree that has yet been made and tested for the severe climate of the Northwest. By using a short root and a long scion in making the graft, and then planting them deep, we induce them to start roots from the scion, and thus usually after the second year the tree is practically on its own root, and if the scion is of a hardy variety, you have a hardy tree, which would not be the case if you had a tree that had been budded or grafted above ground on a tender seedling. Apple seedlings are always of doubtful hardiness, therefore a budded tree cannot be relied upon.

It is being recommended by our Government Experiment Stations that we bud upon "Pyrus Baccatta," or other hardy crab stocks. While we have hopes that this is going to give us something of real value for the far North, we must admit that it is yet in the experimental stage. We have a stock of these trees, which are listed on a succeeding page. 


\section{SUMMER APPLES.}

YELLOW TRANSPARENT-Of Russian origin; tree a good grower and very hardy. A young and abundant bearer; fruit medium size, round, and when fully ripe pale yellow; flesh tender, juicy, sub-acid,

DUCHESS OF OLDENBERG-Large size, productive and very hardy; quite showy; very tart and a good cooker. Tree a very poor grower in the nursery. We have more small crooked trees of this variety than any other we propagate, but as it attains age it makes a fine, strong orchard tree. The fruit ripens middle of August, and is very perishable; however, the fruit is good for cooking from the time it is half grown, which prolongs its season considerably.

\section{FALL APPLES.}

WEALTHY - A seedling originated in Minnesota; very hardy; an abundant and early bearer; fruit large, dark crimson; flesh crisp, sub-acid, white tinged with red; good quality. Tree a fine upright grower, both in the nursery and orchard. Season, October to December.

HIBERNAL (Russian)-Without doubt the hardiest of the welltested varieties. The tree is spreading in habit, and is considerably hardier than the Oldenberg. A rather early and regular bearer, and productive. It seldom blights severely. The fruit is large, and color much like the Oldenberg; excellent for cooking, and very good for table use when fully ripe. Season, late autumn and early winter.

HAAS-Medium to large; slightly conical and somewhat ribbed; pale greenish yellow, shaded and striped with red; flesh fine, white, tender, juicy, sub acid, good; bears early and abundantly; strong grower; moderately hardy. Season, Sep1...her to October.

IOWA BLUSH-Medium in size; roun.lish, conical; whitish yeliow, with delicate pink cheek; quality fine, tart. Tree a strong grower and quite hardy. Season, November to January.

ANISEM (Russian)-Tree fully as hardy as Wealthy, and fre? from blight. A strong grower, but not very straight. A good bearer, of medium size, fine flavored, red and yellow fruit. Season, late fall or early winter.

PATTEN'S GREENING-Originated by $\dot{C}$. G. Patten of Charles City, Iowa. from seed of the Duchess. Not quite so hardy as the Duchess with me; fruit about the same size and shape, but greenish color. A fair eating and excellent cooking apple. Tree is rathe: crooked in nursery, but makes a fine spreading orchard tree. A strong grower. Season, December to February.

\section{WINTER APPLES.}

PEERLESS-Tree a very fine, straight, upright grower. Originated from seed of Duchess planted by J. G. Miller, near Faribault, Minn. It is quite hardy and productive; fruit medium size, of a pleasant. sub-acid flavor; color red on a yellowish-green ground; stem short and hangs on the tree well; perfectly hardy here.

PEWAUKEE-Seedling from the Duchess. Fruit medium to large. surface bright yellow. partially covered with bright red; flesh elluwish-white, juicy, sub-acid, with a rich, aromatic flavor. A str'ng grower; hardy. Season, December to March.

EEN DAVIS-A tree highly esteemed in the West. Fruit conically shaped, striped, and of fair quality, juicy, sub-acid; very productive: quite hardy here. but should not be planted much farther north. Season. December to February.

LONGFIELD-Tree rather crooked in nursery, but makes a good orchard tret: quite a strong grnwer. Very hardy, and an early and abundant bearer. Fruit small to medium, yellow, tender and juicy, and a good keeper.

WOLF RIVER-Tree quite hardy, strong grower and a moderate bearer Fruit greenish-yellow, shaded with red, and very large; a great show apple; quality just medium. Season, early winter.

SALOME-Tree a medium and rather upright grower; quite hardy; fruit medium size, roundish, conical, pale yellow, splashed with red and sprinkled with white dots; flesh tender, juicy, mild, sub-acid first-class. Season. January to June.

NORTHWESTERN GREENING-Tree of Wisconsin origin; an extremely fine shaped, good growing tree in the nursery and orchard. Fruit large and greenish-yellow; good quality. It is claimed to keep well until June. Tree is quite hardy, and will probably succeed as far nortn as the Wealthy; very promising.

WALBRIDGE-A vigorous, upright grower; quite hardy here; fruit medium size, roundish, oblate; skin deep yellow, with a shade of brownish red where exposed; flesh yellowish, juicy, mild, sub-acıd, very good. Season, April to June.

MALINDA-Tree Juite hardy here. A medium grower; fruit of medium to large size, conically shaped; color greenish-yellow, sometimes slightly tinged with red; quality first-class, and an excellent keeper; highly recommended in Minnesota. A rather tardy but abundant bearer. Season. February to March.

\section{HYBRID OR CRAB APPLES.}

WHITNEY NO. 20-A beautiful, upright growing tree, and is very hardy. Fruit of good size, red and yellow striped, conical in shape, very crisp, tender and juicy, slightly acid. A very delicious eating apple, and is one of the best for canning whole. Ripens late in August, and is a poor keeper. 
HYSLOP-An old and well-known crab; a good grower and very hardy; fruit larger than Transcendant; deep crimson in color; flesh white, tinged with red; abundant bearer; blights badly. Seasun, September to December.

VIRGINIA-Tree very hardy and free from blight; a strong grower; it will probably stand more adverse conditions than any other apple known. Fruit medium size and almost completely coyered with red. Ripens in September and keeps for two months.

SWEET RUSSET-Tree a fairly good grower and of good form; perfectly hardy. Fruit large, round and confcal, green russet with faint blush; very rich and sweet, the best of its season for eating from the hand or for cooking. Season, August and September.

SOULARD-Tree quite hardy, and a good, sturdy grower, of the wild crab type. Fruit yellowish-green, nearly as large as the Whitney, but flattened in shape, and of a quince flavor; desirable to have a few for flavoring other varieties; very productive, and will-keep all winter.

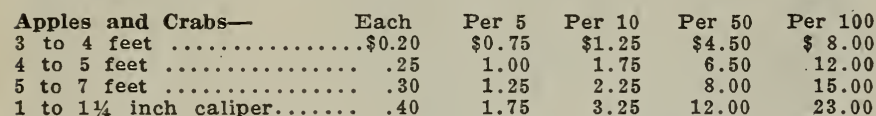

Duchess, Hibernal and Patten's Greening budded on Pyrus Baccatta stocks-

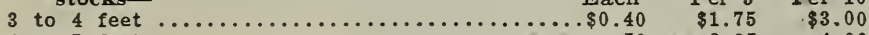

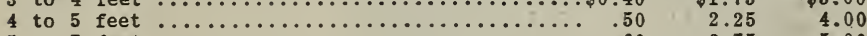

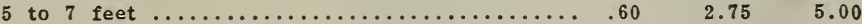

Note-We have only a limited number of the large trees (1 inch caliper and up) listed above, but will sell at the listed price until sold out. These trees are a bargain for near-by planters. We have a few in larger sizes. Ask for prices.

If anything else is wanted in the line of apple trees, write us. We have in stock a number of varieties and sizes not listed here, which we can supply.in small quantities.

\section{APRICOTS}

ALEXANDER-Very hardy; an immense bearer. Fruit" large, yellow, flecked with red; very beautiful, sweet and delicious. Season. July.

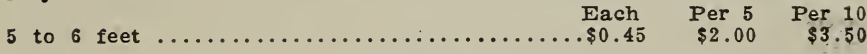

\section{PEARS}

KIEFFER-Tree a vigorous grower; seldum blights. Fruit of large size, rich color and fine flavor. Season, October and November. $\begin{array}{lll}\text { Each Per } 5 \text { Per } 10 & 0\end{array}$

\section{PLUMS}

Since the test winter of 1898 and 1899 there has been a general demand for plum trees on hardy native roots. There is a general tendency, of course, for th-se native roots to throw up sprouts that are troublesome, if neglected; but if they are kept down when small there is little expense, and they are decidedly preferable to foreign roots, that are liable to kill out the first hard winter.

For a plum orchard for this section and farther north, I would plant the American varieties on native roots, which are perfectly hardy anywhere in the Dakotas or Minnesota. Would choose a rather moist, rich soil, planting the rows 16 feet apart, with the trees 8 to 10 feet apart in the row, rows running north and south, or better still, approximately, northeast and southwest. Give clean culture right along, even after trees come into bearing. A light mulch around the tree at the beginning of winter will be very beneficial; just enough so that it can be readily cultivated in the following summer.

I list mostly the native sorts. It will not pay to try to do much with the European and Japan varieties here, as they are not well adapted to our climate, and the quality is not so good as the natives. However, we have a few of the Japs if desired. 
I have also a good stock of most of the varieties listed herein, on peach roots. These are desirable here and farther south, if non-sprouters are insisted upon; but they will not be safe much north of this.

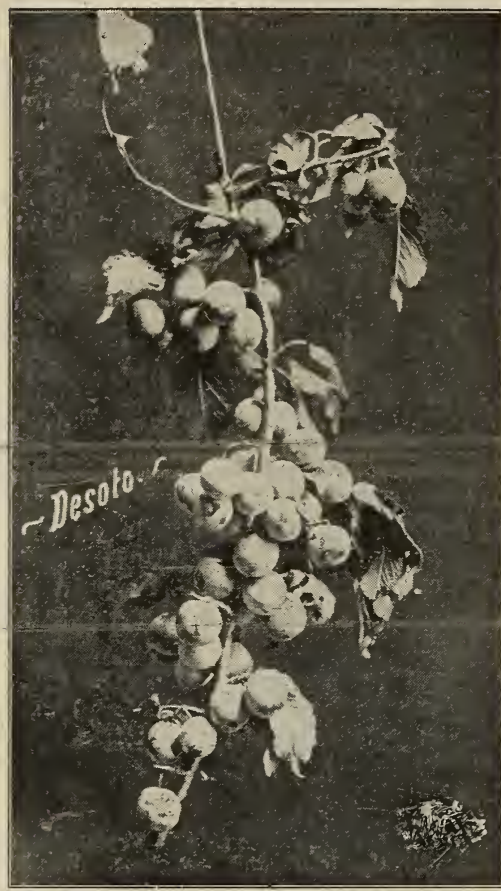

DE SOTO-Tree is extremely hardy, a moderate grower. In fact, does not make a very large tree, as it comes into bearing young and bears so heavily as to retard growth of tree. It is an annual bearer, and unless fruit is thinned is liable to nverbear, making fruit small. Fruit good size and quality. Color a rich golden yellow when it begins to ripen, gradually turning red at full maturity, making it a showy plum in all stages of ripening. Ripens in August.

FOREST GARDEN - A strong growing tree, needs a little attention to keep tree in shape to avoid splitting ind breaking of limbs. A profuse bearer and perfectly hardy; fruit 1 to $1 \frac{1 / 2}{2}$ inches in liameter, nearly round, motled red and yellow; rich and sweet; a very popular and vell-known variety. Ripens sarly in August.

WOLF-Tree is a very rood grower, making a fine irchard tree. Fruit about he size of the De Soto, iometimes $1 \frac{1}{2}$ inches or more n diameter; a perfect freetone. The pit being small, slean and white, and the ilavor a sharp, sprightly, pleasant acid, making it very desirable for cooking in any form. A very profitable sort, and extremely hardy. Ripens late in August.

MINER-Tree a strong, vigorous grower; fruit large, deep red and of a good quality; a valuable variety to raise in the south part of the state, but it cannot be recommended for northern sections, for the reason that it is not hardy enough and fruit ripens late. It is rather poor self-fertilizer, and should be planted near some other variety to make it real productive. Ripens 1 st to 15 th of September which makes it very desirable, for coming after other varieties are all out of the market, it finds ready sale at a good price.

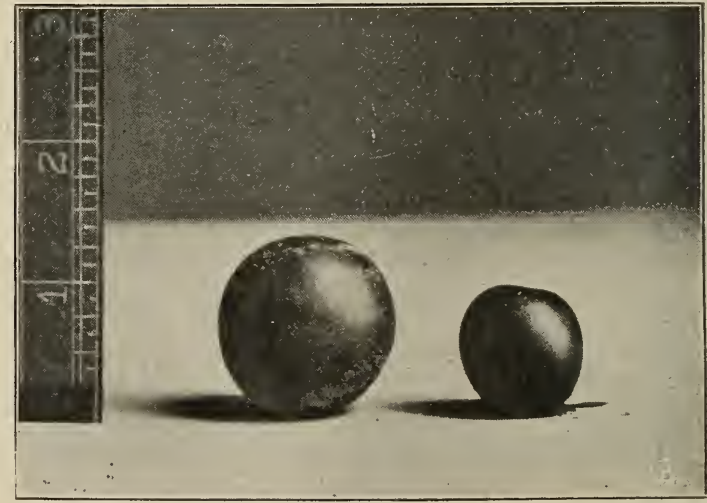

DeSoto Compass

Showing Comparative Size.

CHENEY - Tree a strong and very upright grower; holds its load of fruit up well, but fruit drops early in season after ripening, and is a very poor 'keeper, but is very large and showy; good to eat from hand, but quality only moderate for cooking. Skin peels off readily, making it fine for dessert; good for home use and near market. 
WXANT-This is naturally a very low-growing, stocky, longlimbed tree, and stands up excellently under its load of fruit; a very heavy bearer. Fruit medium to large size, and good quality, but somewhat irregular in shape and size; the color is dull red and yellow, so that it lacks in appearance to make it an attractive market variety. Season, about the same as Wolf.

HAWKEYE-Tree a good grower and perfectly hardy. Fruit large, round, and very showy. A good market variety; quality just fair. Season, about the same as Wolf.

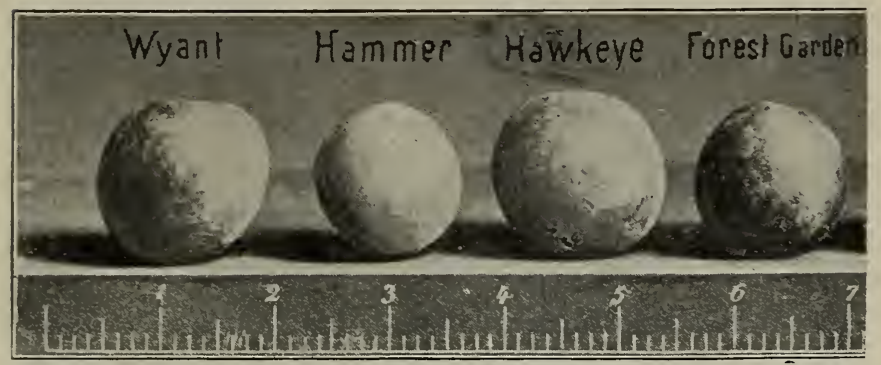

HAMMER-A good grower and perfectly hardy. Fruit medium size and excellent quality; color red and yellow, quite attractive; very prolific. Season Iate.

SURPRISE-A strong growing tree of the Miner family, but much hardier than Miner. Fruit large and red, excellent for dessert and market; flesh rich and sugary, a delicious flavor; very prolific and very promising for the Northwest.

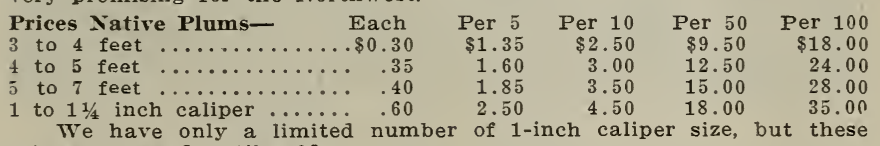
prices are good until sold.

\section{JAPANESE PLUMS.}

ABUNDANCE (Botan)-One of the best Japan plums. The tree is a very rapid grower, healthy in limb and foliage; comes into bear-. ing remarkably young, and yields abundantly. The fruit is full, medium size, color a rich, bright cherry-red, with a distinct bloom. and highly perfumed; flesh light yellow, very juicy and tender, and of excellent quality. Vigorous; hardy south from here.

BURBANK-Tree a very vigorous grower, early and very heavy bearer. Fruit very large, yellowish ground, with red cheek in the sun; flesh yellow, firm and very sweet when fully ripe; extremely small pit, wnich clings. Middle of June.

Japanese Plums- Each Per 5 Per 10

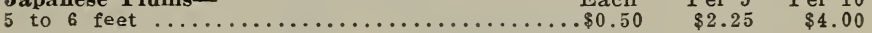

\section{CHERRIES}

Cherries are doing quite well throughout the West on the high lands, and bid fair to become a profitable crop to grow here. They seem to thrive best on a rather well-drained soil. They will not do well with their feet in the water. Plant in rows 20 feet apart, with trees 12 to 14 feet apart in the row.

EARLY RICHMOND-An early, red, acid cherry, very valuable for cooking. Tree a free grower, hardy, healthy and very productive. It is the leading market variety for this section. Ripens in June.

LARGE MONTMORENCY-A large cherry of good quality, and is becoming very popular in many sections, but has not been tested long here. We have many hopes for it, however.

WRAGG-This is a very good late variety. Fruit about the same size and quality as the Early Richmond. It is a very prolific bearer, and very profitable.

\begin{tabular}{|c|c|c|c|c|c|}
\hline Cherries- & Each & Per 5 & Per 10 & Per 50 & Per 100 \\
\hline 3 to 4 feet & $\$ 0^{\prime} 30$ & $\$ 1.25$ & $\$ 2.25$ & $\$ 9.50$ & $\$ 18.00$ \\
\hline 4 to 5 feet & .40 & 1.75 & 3.25 & 14.00 & 26 . \\
\hline $4 \frac{1}{2}$ to $6 \mathrm{fee}$ & .50 & 2,25 & 400 & 17.00 & 32,00 \\
\hline
\end{tabular}

$41 / 2$ to 6 feet ............ $.50 \quad 2.25 \quad 4.00 \quad 17.00 \quad 32.00$

COMPASS-This originated with H. Knudson of Springfield, Minn., and is believed to be a cross between the Western Sand Cherry and the Miner Plum. Its habit of growth is like the Miner, while the leaf, twig and bark very much resemble the Sand Cherry. It is a strong grower, and makes a very fine orchard tree. Fruit about an inch in diameter, and is as much a plum as it is a cherry. The shape is oblong and slightly flattened. The pit is between the ordinary American plum and Early Richmond pit in shape and size. It has a flavor 
peculiar to itself, very palatable and rich. An immense and early bearer, if well pollenized; should be planted near other plum trees. Tree perfectly hardy as far north as Manitoba.

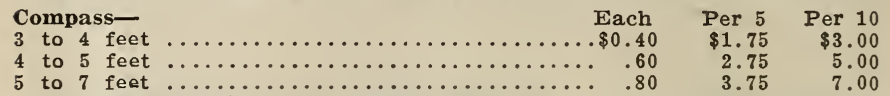

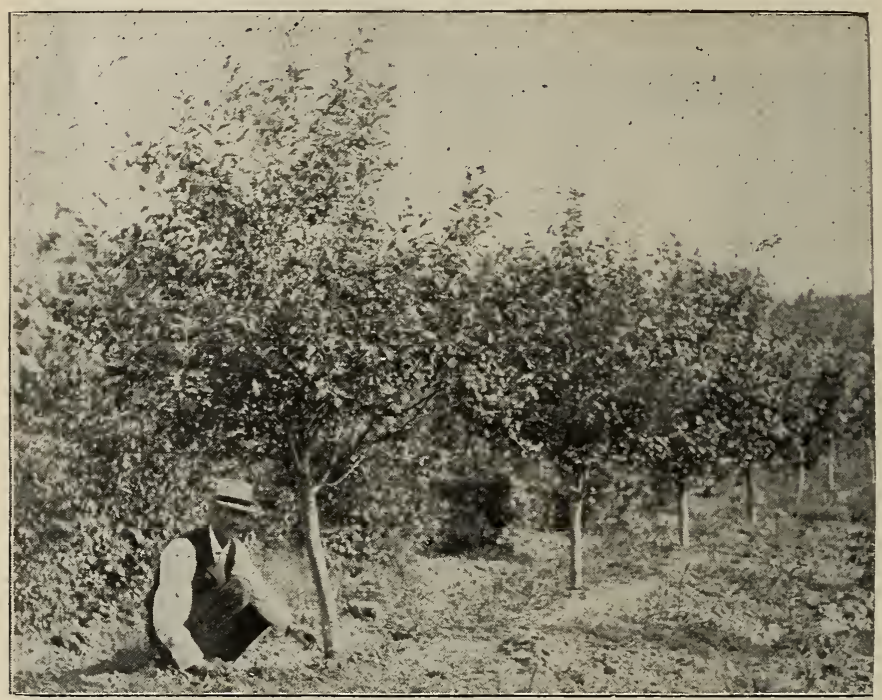

Compass in Bearing.

SAND CHERRY (Prunus Pumilla)-A native, of dwarfish habits, perfectly hardy anywhere in the Northwest. Fruit about the size of Early Richmond; color dark brown to black; somewhat astringent to eat from the hand, but cooks well. Very early and abundant bearer; can be planted about as close as currants. Very desirable in the Northwest where better cherries cannot be grown. Ripens in July and August, after other cherries are gone.

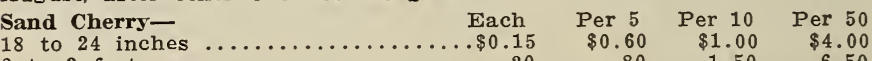

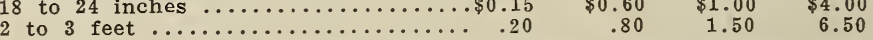

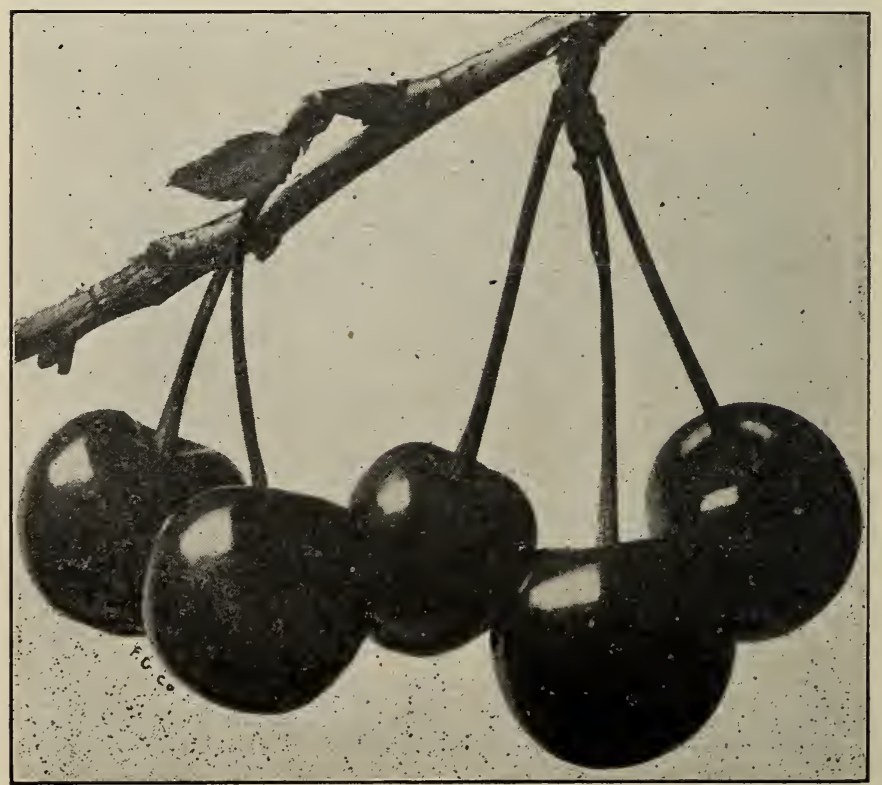

Wragg Cherry 
CHOKE CHERRT (Prunus Virginiana)-A native that is extremely hardy and a prolific bearer. The fruit, although rather small and astringent, is valuable to grow where better varieties will not succeed.

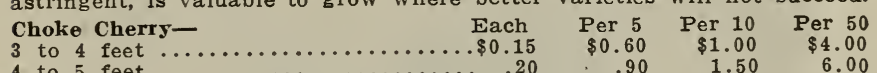

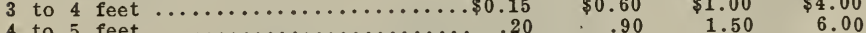

\section{BUFFALO BERRY}

BUFFALO BERRY (Sheperdia Argentia)-A native shrub or tree, sometimes growing to a height of 15 feet or more; perfectly hardy anywhere; bears abundantly if properly fertilized; should be planted in groups containing both pistillates and staminates; fruit about the size and color of Red Dutch currants; quite tart and juicy, and makes a delicious jelly. A very ornamental shrub, and is also quite useful for hedges.

I am now prepared to furnish them in either sex desired. The female only bears the fruit; the male is no account, except as a fertilizer. Unless otherwise ordered, we put in 3 female plants to each male plant.

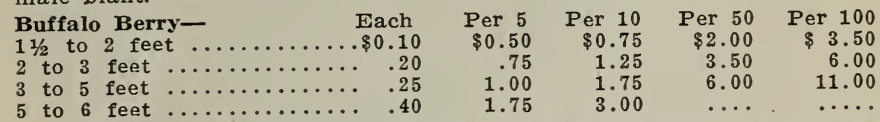

DWARF JUNE BERRY (Suscutan or Sugar-berry)-The fruit is borne in clusters, reddish-purple in color, changing to bluish-black In flavor it is a mild, rich sub-acid; excellent as a dessert fruit or In flaver It is extremely hardy. In habit it is similar to the currant, canned. It is extremely hardy. In habit it is similar to the currant, posed of fine white petals. A fine ornamental plant.

June Berry

$$
\text { Each }
$$

\section{GRAPES}

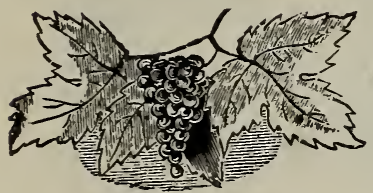

Plant in rows 8 to 12 feet apart and 6 feet apart in row, on good, well-drained soil; cultivate clean and the second spring after planting set posts 5 feet high and 20 feet apart along the rows. On these stretch three or four smooth fence wires 18 inches apart. Select two of the strongest canes, cut to a length of four feet (remove all other canes), and tie these two loosely, one each way on the lower wire, allowing the shoots to run up to the other wires. In the fall cut these laterals back to two or three buds, and continue this year after year, gradually increasing the bearing wood each year as the vine gets larger. Renew these canes once in every four years. Prune in fall, and lay down and cover with coarse litter; keep suckers pinched off during summer.

CONCORD-A vigorous, hardy vine; berries large and black; skin thin, flesh juicy and sweet; ripens early in September; the leading market variety.

BETA-This is supposed to be a cross between the Concord and the Minnesota wild grape. In size and flavor the fruit is about midway between these two varieties, while in hardiness it appears to be equal to the native wild variety, therefore making it very valuable for the far North, where other varieties cannot be successfully grown.

DELAWARE-Red; bunch small, compact, sometimes shouldered; berries small; skin thin, but firm; flesh juicy, very sweet and refreshing; of best quality for both table and wine; ripens with Concord or a little before. Vine hardy, productive, a moderate grower; requires rich soil and good culture.

MOORE'S EARLY-A large black grape of the Concord type, the entire crop ripening before the Concord; bunch medium; berries large, with blue bloom; flesh pulpy, of medium quality; vine hardy, moderately productive, better as it attains age. It is planted extensively as a market sort.

MARTHA-Bunches and berries of medium size, greenish-white, with a thin bloom; flesh tender, with a very little pulp; juicy, sweet and rich; hardy and productive; ripens with Concord.

JANESVILLE-A very hardy variety; it has borne right along with me without any winter protection. Bunch short, close and compact; berry medium size, black; quality fair when fully ripe; very productive.

WORDEN-Black. Very vigorous hardy and productive; excellent quality; ripens 10 days in advance of the Concord. All around it is a better varietv. 


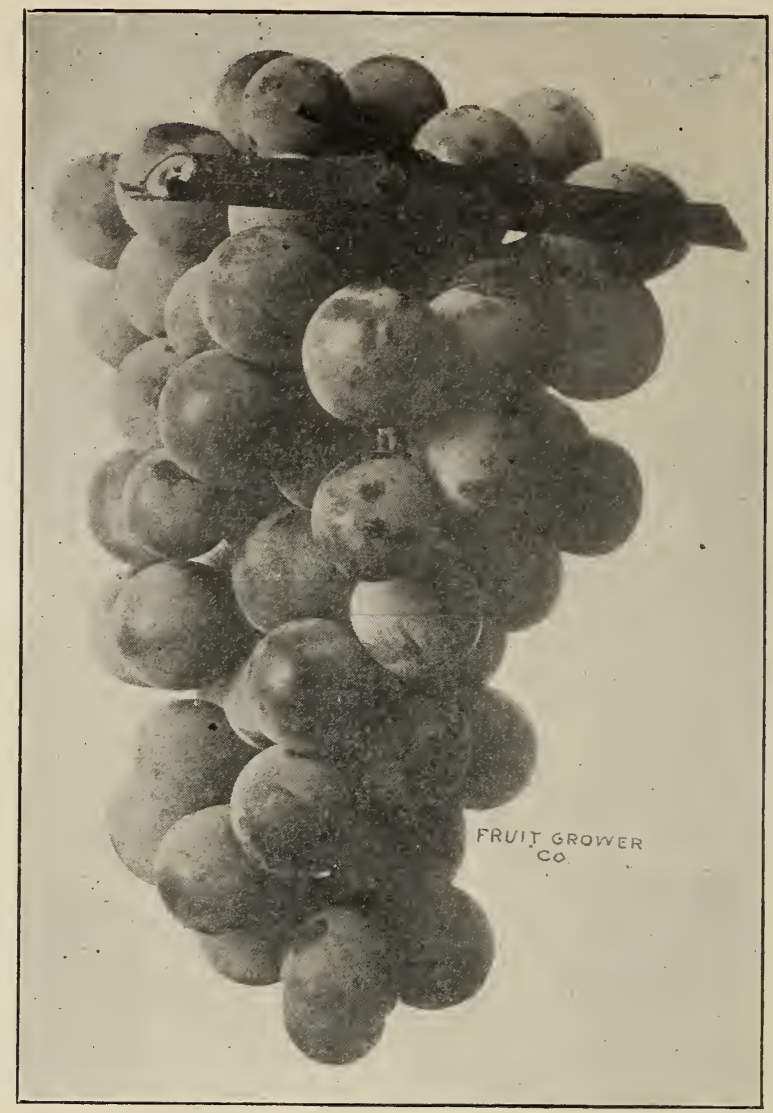

Concord

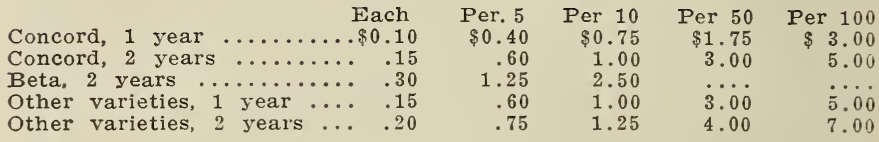

\section{GOOSEBERRIES}

Give same treatment and care as previously instructed for currants. Gooseberries are very easily grown, and should be planted by everyone.

HOUGHTON-A medium sized. American variety: bears abundant and regular crops, and never mildews; fruit smooth, red, tender and very good; hardy nearly everywhere.

CHAMPION-A fine, vigorous grower; very productive and free from mildew; fruit larger than Houghton and of a greenish color; very promising.

$\begin{array}{llll}\text { Each Per } 5 & \text { Per } 10 & \text { Per } 50 \text { Per } 100\end{array}$ ar, No. $1 \ldots \$ 0.20 \quad \$ 0.75 \quad \$ 1.40 \quad \$ 3.50 \quad \$ 6.50$

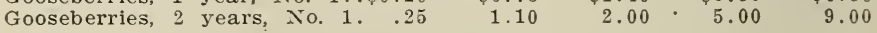

\section{CURRANTS}

Plow deep, and have the soil well pulverized before planting. We plant rows 8 feet apart and 4 feet apart in the rows, giving good, clean culture, and manure well. Cut out old wood occasionally, and keep the bush vigorous and healthy. The varieties listed here are all perfectly hardy, enduring well our coldest winters and driest summers. The currant is very easily grown and cared for. If the currant worm appears. dust with hellebore. 


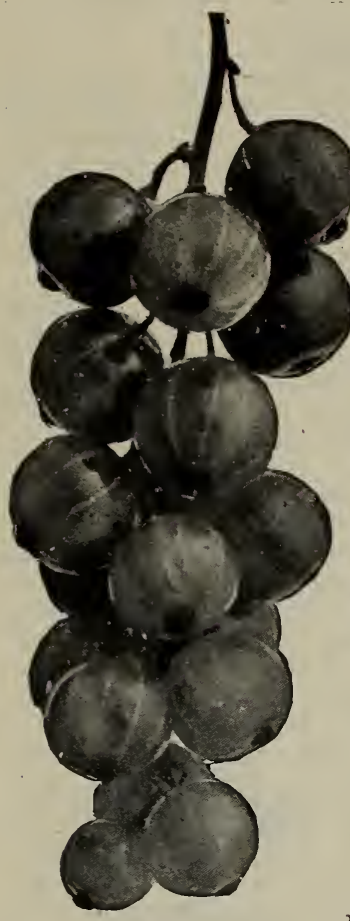

RED DUTCH-A hardy, well-known standard variety; early; a prolific bearer, and does well anywhere. It is, perhaps, planted more extensively than any other variety.

VICTORIA-Large; red; late; seems very well adapted to South Dakota; has produced excellent crops with me annually. It is a strong, stocky grower: has heary foliage, which protects the fruit from the sun.

NORTH STAR-A very productive red variety. Bunches large; berries large, sweet and rich; a good market variety. and excellent for jelly; a strong, vigor ous grower.

FAY'S PROLIFIC-Largest berry of all; fine flavored; attractive red color; straggling growth; branches break very easily; not long-lived here.

WHITE GRAPE-So far has proven the best bearer I have fruited here, bearing a full crop annually of large bunches and large sized fruit. Good grower.

BLACK NAPLES-A very rank, strono grower, and very productive; fruit large, black, and of a musky flavor; a 1 heres well to the bush; excellent for cooking.

CRANDALL-A seedling of the Missouri River wild currant. which it resembles very much. but it is much larger, and much more prolific than the common wild strain.

Currants, 1 Each Per 5 Per 10 Per 50 Per 100

\section{RASPBERRIES}

Plant in rows 8 feet apart and 3 feet apart in rows; give clean culture; keep down all suckers and weeds. Lay down and cover with earth in fall; although this covering may not always be necessary to prevent winter-killing, they will produce enough more fruit to pay abundantly for the extra labor nerformed.

TURNER-Red; vigorous grower; early; fruit of excellent quality; a good bearer and very hardy; one of the best known varieties, and correspondingly desirable; a reliable annilal bearer.

LOUDEN-The best mid-season berry. Its points of superiority are vigor of growth, large fruit, beautiful, rich, dark crimson color, of good quality, marvelous productiveness and hardiness. It stands shipping the best, and will remain on the bushes the longest of any variety.

OHIO-Hardy, and claimed to be the best producer among the blackcaps; medium size, fine flavor and a strong grower.

GREGG-The largest of the blackcaps; good quality; not quite so hardy as others named; should have winter protection to make it at all profitable in this vicinity.

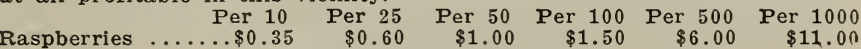

\section{BLACKBERRIES}

Blackberries are of but little value in this locality, and are seldom very productive, but last summer we had an enormous crop of luscious fruit, so we are inclined to take new courage. They may do better in the future when our atmosphere becomes less arid.

They are very profitable, however, where they thrive, especially near the Great Lakes or other large bodies of water in a humid atmosphere.

ANCIENT BRITON-One of the best of the hardy varieties: vigorous grower; berries of good size and fine quality; a good market berry: very prolific.

STONE'S HARDY-One of the lowest growing blackberries; very hardy and productive.

SNYDER-Very hardy, productive and well-known; a desirable variety for the Northwest.

$\begin{array}{rrrrrr}\text { Per } 10 & \text { Per } 25 & \text { Per } 50 & \text { Per } 100 & \text { Per } 1000 \\ \text { Blackberries } \ldots \ldots \ldots \ldots \ldots \ldots \$ 0.40 & \$ 0.80 & \$ 1.50 & \$ 2.50 & \$ 15.00\end{array}$




\section{DEWBERRIES}

The dewberry is similar to the blackberry, but being of a trailing habit, is more easily protected during the winter. We have the Lucretia, which is one of the best varieties, being a good sized berry, hardy and productive.

Lucretia

$$
\begin{array}{cccc}
\text { Per 10 } & \text { Per 25 } & \text { Per 50 } & \text { Per } 100 \\
\$ \$ 0.50 & \$ 1.00 & \$ 1.50 & \$ 2.50
\end{array}
$$

\section{STRAWBERRIES}

Plant in rows 4 feet apart, with plants 1 foot apart in the row. In planting great care should be taken to get roots well down in the ground; but don't plant so deep that the crown of the plant will be covered with dirt by the rain; if you do, they will rot and die. Mulch late in the fall with hay or corn stalks to avoid foul seeds, which are so numerous in straw.

Staminate varieties bear by themselves, but the pistillates require a staminate variety every third or fourth row to make them productive. Please bear this in mind when making selections. Plant at least two rows of pistillates to one of staminates, as they are more productive, if properly fertilized.

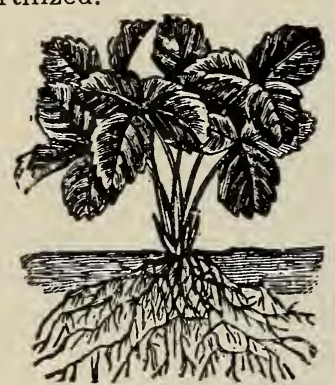

biznt Way to Plant

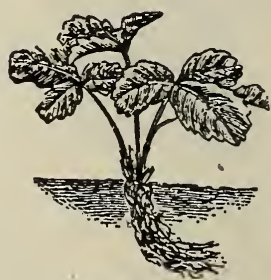

Wrong Way to Plant

Cli:-CWN' (Pistillate)-One of the most productive sorts; good cuality anc large; sucreeds well almost anywhere, if properly fertilized; herries somewhat irregular in form.

WARIELID NO. $\%$ (Pistillate)-Plant a very vigorous grower; endures droutl, well; blossoms and ripens with Crescent; it is very productive, good size and good shipper; a deep, showy red.

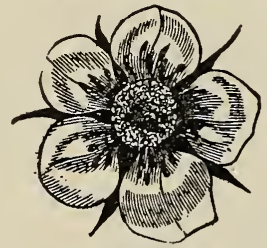

Staminate

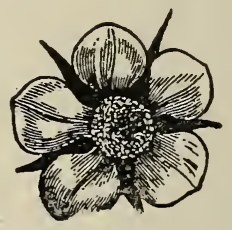

Pistillate

BRANDYWINE (Staminate)-Season medium to late. It is one of $\cdots$ fr favorites. It is one of the heavirst fruiters, and a splendid shiper, and a "catcher" on the market. Berries are very large, deep red to center; stems short and stowt, and holds its great load of berries w il up from the ground. One if the strongest pollenizers for pistil1.tes of its season.

SENATOR DUNLAP (Staminate) - It is equal to the Warfield in size and nroductiveness. and is sweeter ind better. It resembles the Warfield in color and shave It is gund wither for home or for market. The plant is very tough, hardy and an exceptionally strong grower; succeeds well in a very wide range of concitions; one of the most popular sorts today. Be sure to include tnis variety in your list: it will pay you. We sometimes think it would be well if the farmer had only this one sort.

BEDERWOOD (Staminate)-Very popular and one of the heaviest fruiters of its season; berries crimson, moderately firı, high quality; a splendid pollenizer; valuable for home use or near market.

All plants will be trimmed of dead leaves, runners, etc., and neatly tied into bunches of 25 plants each. In criering, please govern yourself accordingly, and order a fuil bunch of each kind, as we will charge the ten rate wher we have to break bunches.

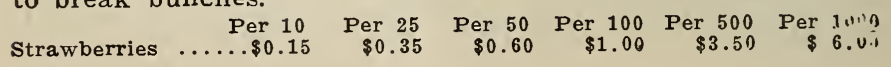




\section{RHUBARB OR PIE PLANT}

This deserves to be ranked among the best early fruits of the garden. It affords the earliest material for pies and tarts, continues long in use, and is valuable for canning. Plant in rows 8 feet apart and 4 feet apart in row, in rich, deeply plowed land. If you use coarse litter for fertilizer, place it on top of the soil, and not in contact with the roots. A heavy mulch is beneficial, and saves cultivation.

MAMMOTH-A very large, early, desirable sort; tender and fine flavored.

$\begin{array}{lrrrrr} & \text { Each } & \text { Per } 5 & \text { Per } 10 & \text { Per 50 } & \text { Per } 100 \\ \text { Large two-year roots } \ldots . . . \$ 0.15 & \$ 0.60 & \$ 1.00 & \$ 4.00 & \$ 7.00 \\ \text { No. 1, one-sear roots } \ldots . . . & .10 & .40 & .75 & 2.50 & 4.00\end{array}$

\section{ASPARAGUS}

This is very easily raised, and affords one of the earliest garden foods. Plant 2 by 4 feet apart, in deep, rich soil, and give good, heavy mulch or thorough cultivation. Manure the ground heavily; give an occasional dressing with salt. Begin cutting for use as soon as the young shoots are large enough in the spring; continue the cutting every second or third day as long as the season lasts, then allow it to grow up unmolested for the balance of the summer, and make a winter protection for the bed.

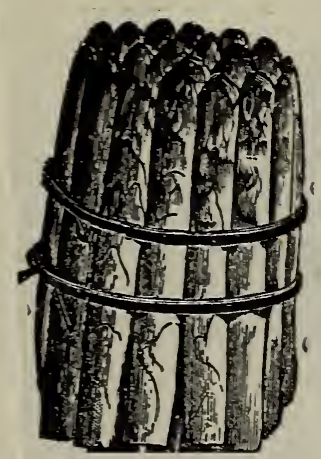

CONOVER'S COLOSSAL-This is a wellknown valuable garden and market sort; a strong grower and very productive; the leading market sort.

COLUMBIAN MAMIOTH WHITE - It produces shoots which are white and remain so as long as fit for use. In addition to the marvelous advantage of its white color, the Columbian Mammoth White is robust and vigorous in habit, and grows larger shoots than the Conover's Colossal.

Per 10 Per 50 Per 100 Per 500 Per 1000 Plants. 1 year. strong-

$$
\$ 0.20 \$ 0.50 \quad \$ 0.90 \quad \$ 2.75 \quad \$ 5.00
$$

Plants, 2 vears, strong-

$.30 \quad .75 \quad 1.25 \quad 3.50 \quad 6.50$

\section{Sending Stock By Mail}

We are better than ever prepared to send stock by mail, and in such a way that it will reach you in good condition, and in the case of small articles at much less cost and trouble to you than any other method of sending, especially to those enjoying the convenience of the Rural Free Delivery. While we do not recommend the mailing of large trees. such as would necessarily need to be cut too severely, there are many small articles which handle all right, some of which I will name here, as follows: Grapes, Currants and Gooseberries, 1 year, weight about 2 ounces each; Raspberries, Blackberries and Dewberries, perhaps $11 / 2$ ounces each; Strawberry plants, about 2 pounds per 100 ; Asparagus plants, 1 year about $1 / 4$ ounce, 2 years $1 / 2$ ounce each; Forest Seedlings, 6 to 12 inches, approximately 1 
pound per $100 ; 12$ to 18 inches, about 2 pounds per 100 trees; cuttings, about $1 \frac{1 / 2}{2}$ pounds per 100 ; small Evergreens, say 4 to 8 inches, about 2 pounds per 100 ; Shrubs, ordinarily about $3 / 4$ pound each; Roses, a little higher; Paeonies, Bleeding Heart and Golden Glow, $3 / 4$ pound; Tiger Lilies, Iris, etc., about 1 ounce each. The weights given are only approximate, and the weight of packing material, which will be about half as much more, must be added. Postal rates on this class of goods is 1 cent for each two ounces, or 8 cents per pound.

In remitting always be sure to send enough to cover cost of postage; if you send too much, we will return balance. No stock can be sent by mail unless it is fully prepaid.

\section{ANYTHING ELSE WANTED}

Should you desire anything in the line of trees, shrubs, etc., write us about it; perhaps we have it, as we have very many varieties not listed in this little catalogue. We do not list anything except such as we have a general stock of, and are liable to have a supply pretty well through the planting season. It is desired to be able to fill all mail orders that come as nearly as possible as the purchaser requests.

\section{Forestry Department}

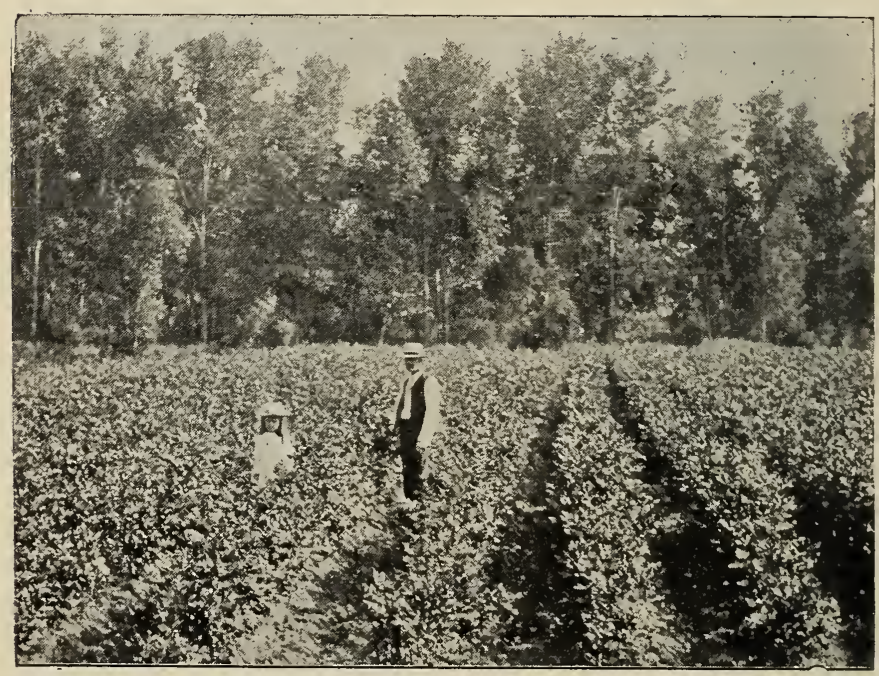

A great many sell forest seedlings, classing them as 1 year-old or two years old, without stating the size. This is very indefinite and generally unsatisfactory to the purchaser, as a 1-year-old seedling might be anywhere from 1 inch up to. 24 inches high, and a 2-year-old anywhere from 4 inches up to 6 feet or more in height. The trees I list here are all nursery grown, with the exception of the cottonwood and - willow, which are mostly river pulled. All seedlings will be carefully counted and tied up neat, straight and tight. All of the smaller sizes under 2 to 3 feet are put up in bunches of 100. Do not ask us to break bunches, as we cannot do it without making an additional charge above the 100 rate. 
FOREST SEEDLINGS

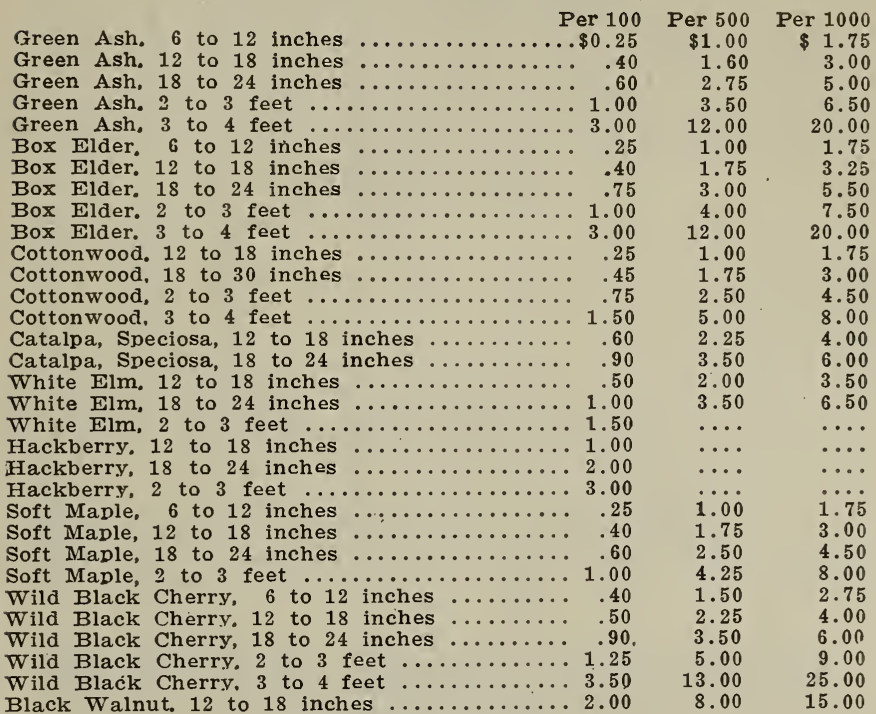

\section{SEEDLINGS FOR HEDGES}

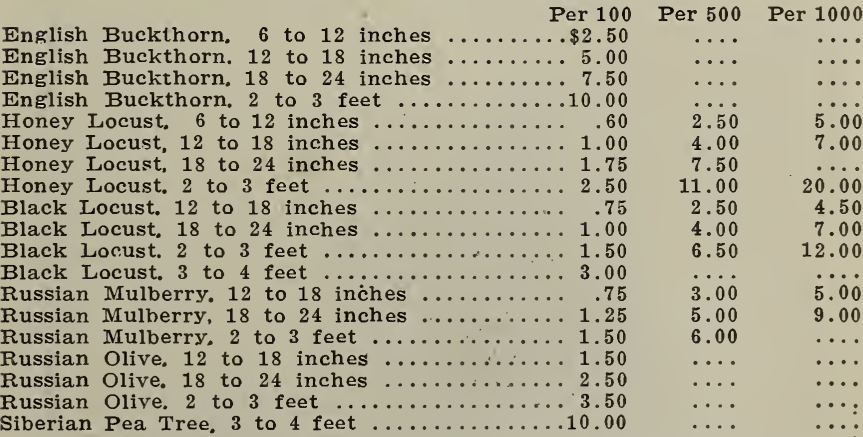

The Russian Artemesia and Tamarix Amurensis are also suitable for hedges. For these, see cuttings below. For evergreen hedging, see Red Cedar and the Spruces in the Evergreen department. The Lilacs, Bush Honeysuckles and Barberry are also fine for hedging. See ornamental shrubs.

\section{CUTTINGS}

Cuttings will be cut about 8 to 9 inches in length and tied into bundles of 100 each, with tops all one way. They can be had any length desired, if ordered a little previous to the time wanted; but if over 9 inches we will charge extra according to length desired. Keep cuttings buried in earth until ready for planting.

Per 100 Per 500 Per 1000

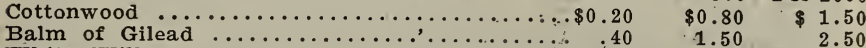

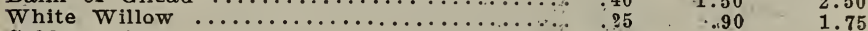

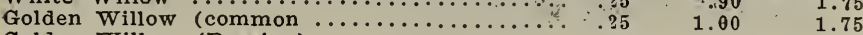

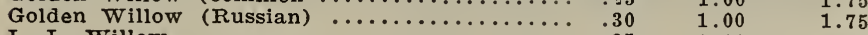

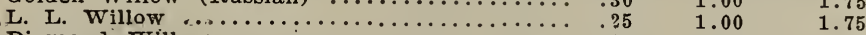

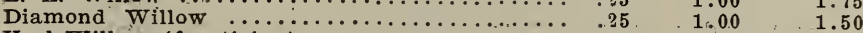

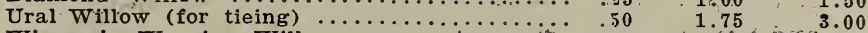

Wisconsin Weeping willow $\ldots \ldots \ldots \ldots \ldots \ldots \ldots .6 \% \ldots$

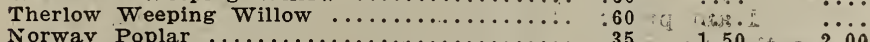

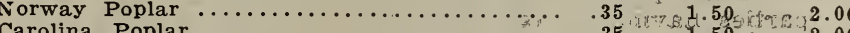

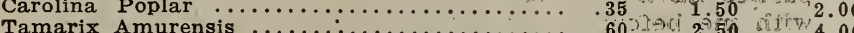

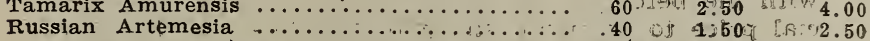
Special prices given on larger quantities than listed. 
The Russian Artemesia makes an excellent low windbreak for quick effect. That is, to plant along beside of or between rows of trees for a sort of undergrowth. It does not grow to a lieight of more than 6 to 8 feet, but it wlll usually do this in about two years from cuttings, if cared for.

\section{TREE SEEDS}

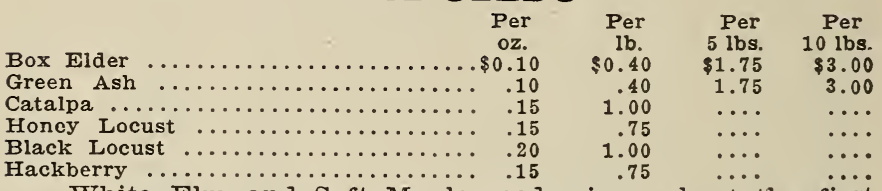

White Elm and Soft Maple seeds ripen about the first of May, and should be planted soon after ripe. Write for prices early in May. We can tell then about what the crop of seed will be.

The average number of marketable seed in a pound is about as follows: Green Ash, 15,000; Box Elder, 10,000; Soft Maple, 5,000; White Elm, 60,000; Catalpa, 30,000; Honey Locust, E,000; Black Locust, 15,000 seeds per pound.

\section{Deciduous Shade and Orna= mental Trees}

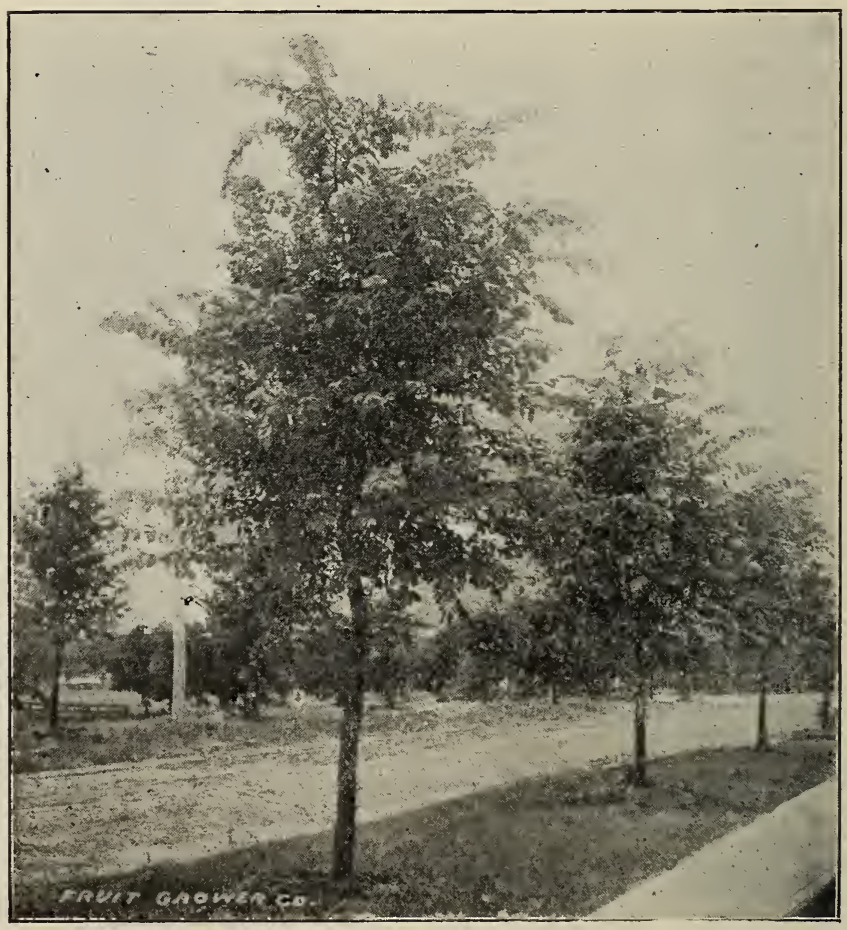

ELM.

In this department I have a very large stock this season, and they are thrifty and straight, having been trimmed and kept in shape during the growing season.

I am prepared to furnish them in large quantities, and parties having charge of parks, etc., will do well to confer with me before making their purchases. Will make a special price to parties desiring to purchase by the carload.

I will also be pleased to furnish estimates and draw up 
plans and designs for parks, public squares, cemeteries and various public and private grounds, making no charge for a reasonable amount of work of this kind where I furnish the trees and plants for same.

AMERICAN WHITE ELM (Clmus Americana)-A native of Suth Daknta and the entire Northwest. One of our best trees for general planting for a shade or street tree; the best of the elms; very hardy; endures well cold, drouth, wind and general neglect. Its wood is tough and valuable for some uses.

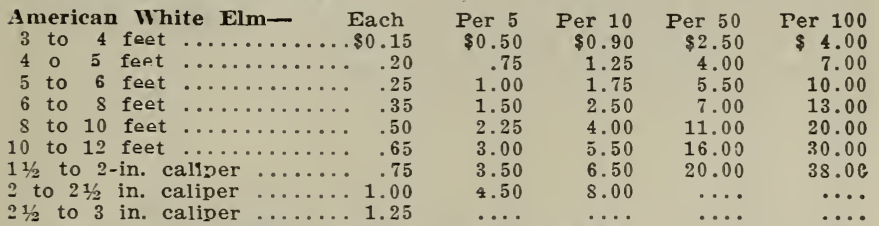

RED OR SLIPPERY ELM (Clmus Pubescens)-A rapid growing, hardy tree, with a tough reddish wood that is much more viluable than that of the White Elm, and would be more valuable to sruw for timber, but it does not do well if planted singly. and makes a poor shade tree, except to plant in groups with other trees.

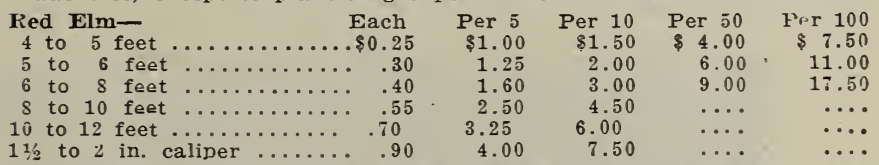

GREEN ASH (Tranxinas Viridis)-This is the native Western Ash. It is really a smaller tree than the White Ash, but thrives better under Western conditions. An upright, medium growing tree. Timber is very valuable; makes a fine. symmetrical round-headed tree if planted singly, with plenty of room; very rugged, hardy and valuable.

Green Ash- Each Per 5 Per 10 Per 50 Per 100

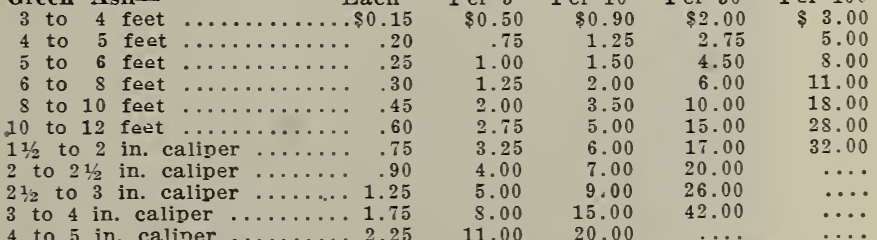

4 to 5 in. caliper ........2.25 11.00 . 20.00 forite for prices if you are interested.

BOX ELDER, ASH LEAVED MAPLE (Acer Negundo)-A native. It is, in fact, indigenous to the entire West, from Texas to Manitoba. It is a rapid grower while young; makes a good shelter-belt quickly; having dense foliage, it soon shades the ground so as to keep down weeds and grass. If shade is requisite, it is one of our best trees. The wood is quite valuable for lumber. Tree is inclined to grow crooked and scrubby unless crowded up by thick planting.

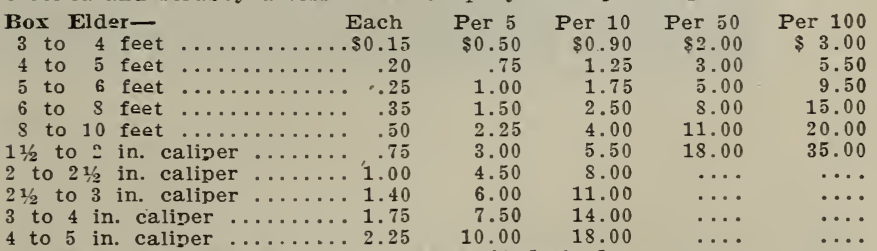

4 to 5 in. caliner ..........2.25

We have larger sized Box Elders, if desired.

HARDY CATALPA (Catalpa Speciosa)-The hardy Western variety. A symmetrical, upright grower; large heart-shaped leaf. It bears large tresses of very beautiful, fragrant flowers. The timber is very desirable and lasting; makes valuable posts. It is not hardq much north of this latitude.

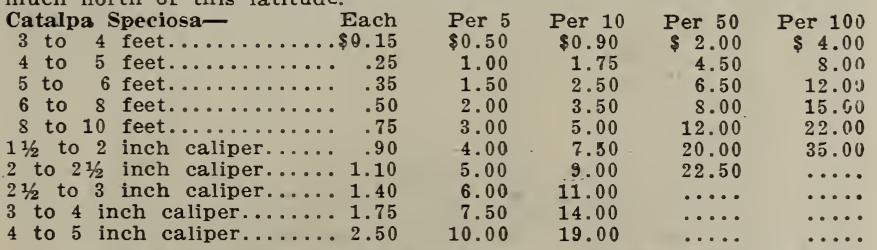

COTTONWOOD (Populus Monilifera)-One of our most rapid growing trees. The wood is soft and of rather poor quality, but it is hard to find another tree that will make more wood in twenty years than the cottonwood. It is a heavy feeder and needs lots of moisture. It has 
recelved lots of kleks irom alf sourees, but after ali that, take the Cottonwood out of South Dakota, and it would leave a mighty big gap. It Is the lumber tree of the Missouri Rlver.

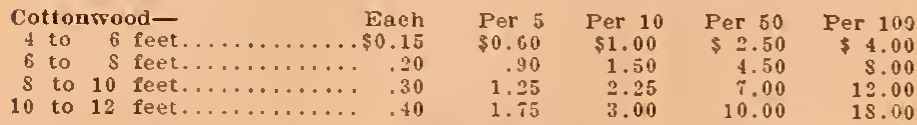

CAROLINA POPLAR (Populus Deltoides Cnrolinensis)-A ver rapld growing. solt wooded tree resembing the Cottonwood somewhat but has a larger leaf and mueh thicker and more spreading top. denser and hearler lollago, $J$ lis being very extensively planted in the clites and towns througheut the United states on aecount of its rapid growth. are to endyre gas and smoke. Perrecty here. It is fret from cotton, which is so disagreeable in the Cotton-

Carolinn Poplar Each Per 5 Per 10 Per 50 Per 100

4 to 6 feet.

8 to $s$ leet.

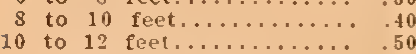

inch caliper.......

2 to $21 / 2$ inch rallper........9.90

3 to to ineh caflper....... 1.20

1.25

1. 75

2.00

4.00

1.25
2.25

4.00
5.50

7.00
10.00

$\begin{array}{lll}3.00 & 8.00 & 15.00\end{array}$

13.00

35.00

.00

$\cdots \cdots$
Inckluerry-

3 to 4 fret...........\$

4 to 5 reet.

is to 8 feet.

10 to 10 iept

to to Inch callper.

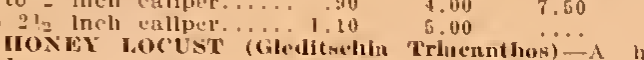
raple

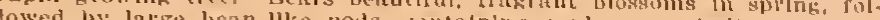
brown bes.

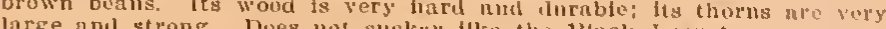

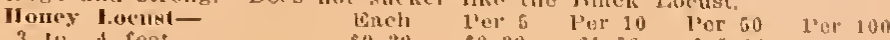

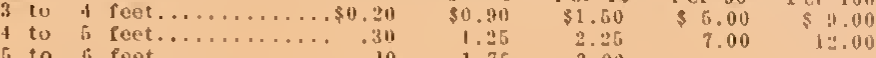

i. to is reet.

8 to 10 feet.

10 to $1: 2$ reet

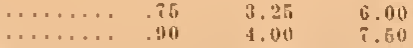

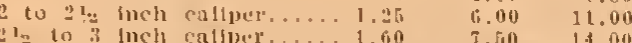

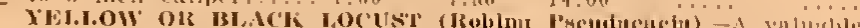

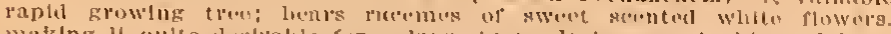

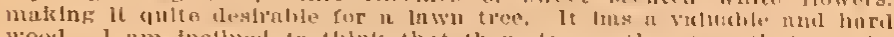

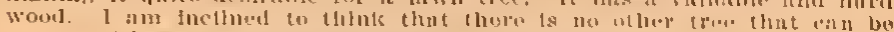

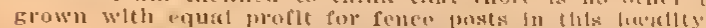

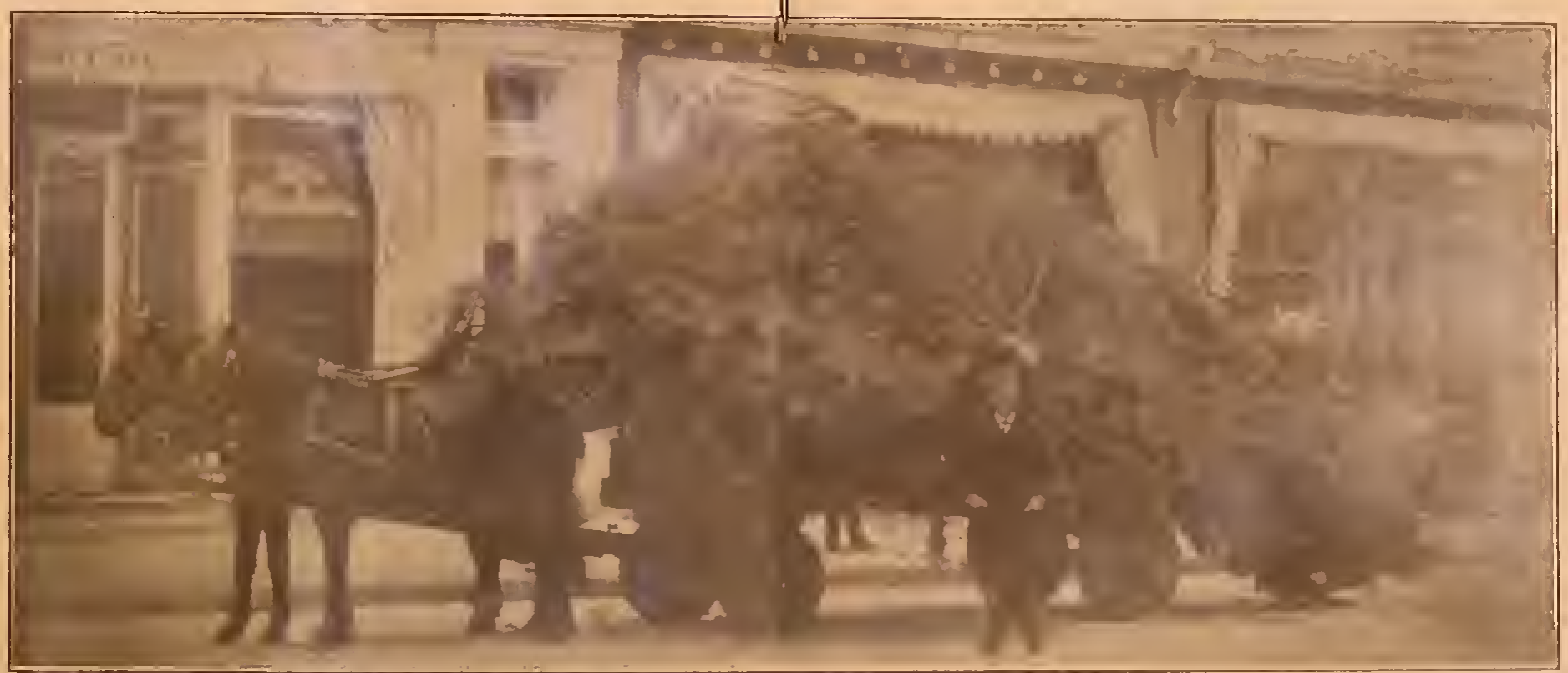

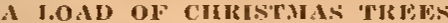

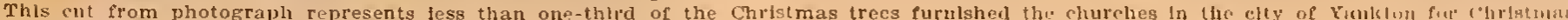
1905. One tree supplied measured 11 inches in dlameler aeross the stump

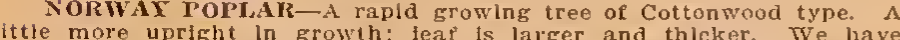
hoped it would stand diouth and be a morc voluable tree than the Cottonwood, but late experlence does not seem to verlify it. We have no th

SIMNER-LFAFED POPLAR (Populus Alba)-A vigorous, hardy tree, of the Poplar famlly. Of lapld growth and spreading habits, Th leaf resembles the Cottonwood in slze and shape, but is more deepl neati. The tree appears to be entlrely al home in South Dakota.

Sliver-Lenfed Pollnr $\quad$ Each Per 5 Per 10 3 to 4 feet...................... $\$ 0.25$ \$1.00 \$1.75

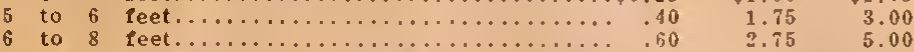

HACKBERRY (Celtls Occiclentalis) - A rugged, hardy, natlve tree grows to good slze; makes a flne, shapely shade tree. Strong $11 \mathrm{mbed}$ and has a hard and durable wood. It is very valuable for timber. ornament and shade, and ought to be more generaliy and extenslveiy grown, and it would be, only that the seed are searee and hard to get, making propagation slow and expenslve. We have a very good stoek of them this season. and are able to make prices quite reasonable. Plant the Hackberry and you will llke lt.

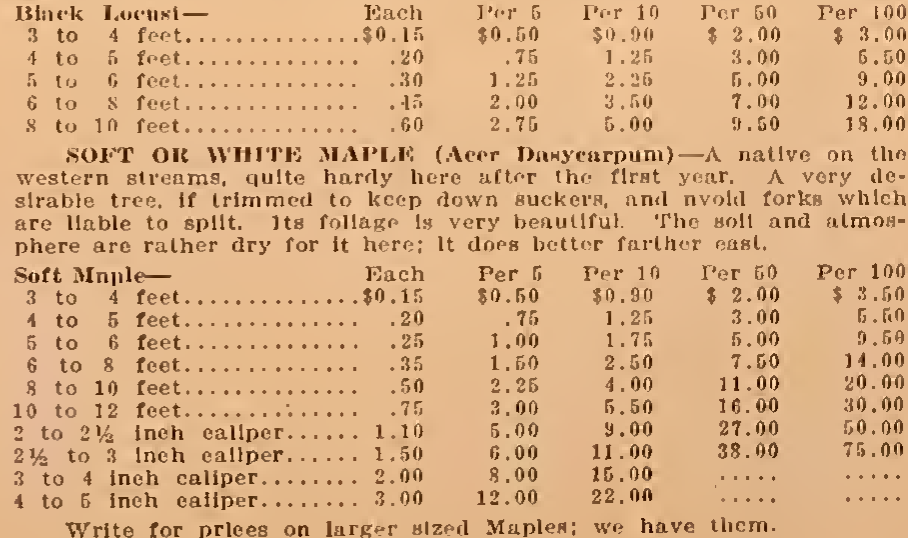


WIER'S CUT-LEAVED MAPLE (Acer dasacarpum Wierii) - A beautiful urnamental type of the Soft Maple with deeply cut leaves. Tree is upright in growth, but branches have a drooping appearance, making it a vity desirable lawn tree. A rapid grower and quite hardy.

Wier's Cut-Leaved Maple-
5 to 6 feet...............................

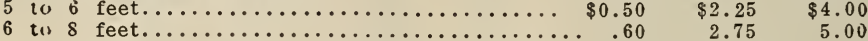

NORWAY MAPLE (Acer Platanoides) - A large round-headed trec resembling in appearance the Sugar Maple, the leaves are large and thicker. Makes a fine formed tree, and promises to be valuable here.

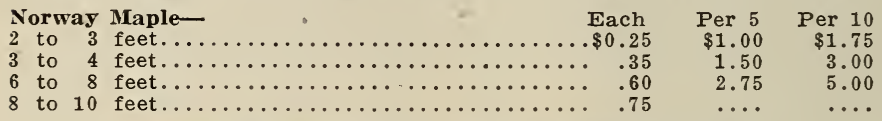

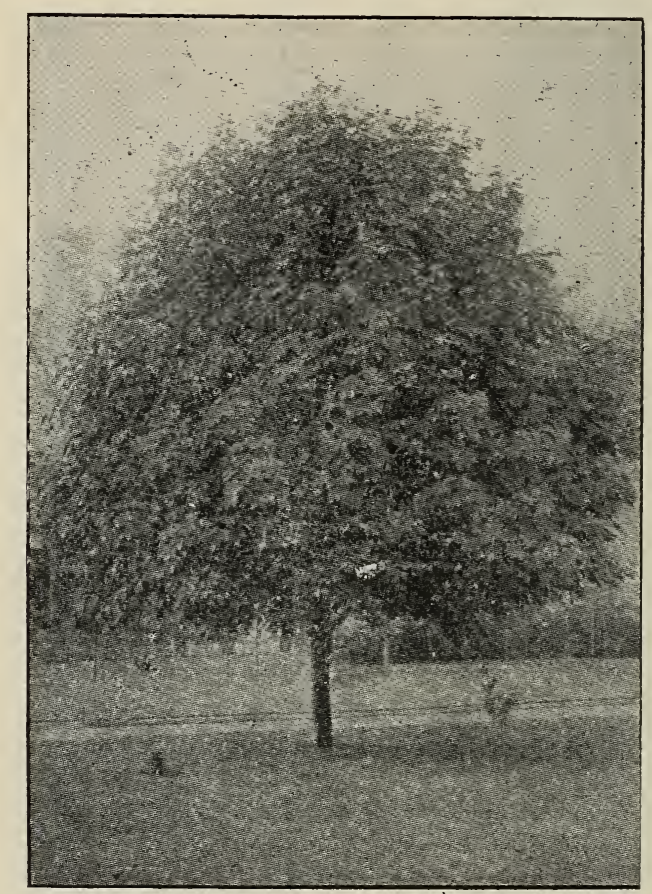

Hard Maple

HARD OR SUGAR MAPLE (Acer Saccharinum)-The Hard Maple is one of America's most beautiful and valuable shade and street trees. It is compact and uniform in shape and makes a dense shade. The foliage is a deep green during the summer and this is followed by the beautiful red and yellow tints in the autumn. It is rather a slow grower in the West and for this reason has never come into general planting. It is a very valuable tree where it does well.

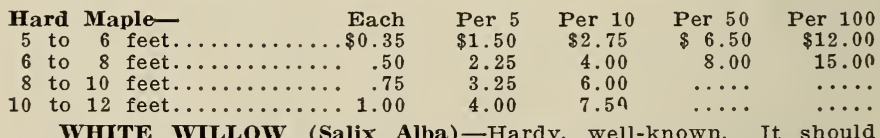

WHITE WILLOW (Salix Alba)-Hardy, well-known. It should be planted on low, wet, rich soil. It is very much benefited by a heavy mulch of litter or manure; of little value on high, dry land here.
White Willow-
3 to 4 feet............\$0.15
4 to 5 feet................. .20
5 to 6 feet............... .30 Per 5 Per 10 Per 50
$\$ 0.50 \$ \$ 0.90$
$\begin{array}{rr}\$ 0.50 & \$ 0.90 \\ .75 & 1.25\end{array}$
$\begin{array}{ll}1.25 & 2.25 \\ 1.75 & 3.00\end{array}$
$\$ 2.50$
3.50
6 to 8 feet............... 40
3.00
Per 100
6.00
.....

GOLDEN WILLOW (Common) (Salix alba vitellina)-Its beautiful golden colored bark makes it desirable for a variety. It is quite hardy and a good grower, where it has plenty of moisture. All of the Willows, in fact, need considerable moisture.

Golden Willow (Common)-Each

3 to 4 feet...........\$0.20

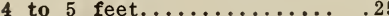

6 to 8 feet................... 45

$\begin{array}{rr}\text { Per 5 } & \text { Per 10 } \\ \$ 0.75 & \$ 1.00 \\ 1.00 & 1.75 \\ 1.50 & 2.75\end{array}$

$1.50 \quad 2.75$

$2.00 \quad 3.50$
Per 50

$\$ 2.50$

3.50

5.50

..
Per 100

$\$ 4.00$

6.00

10.00 
GOLDEN WHLLOW (Russian) (Salix aurea)-Similar to Common Golden except that the bark is more of a reddish shade; it is fully as strong a grower and is more hardy and will stand as far north as Manitoba.

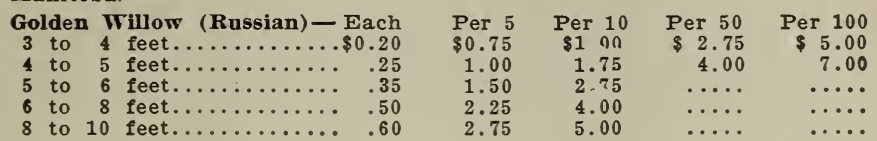

LAUREL LEAVED WHLOW (Salix Laurafolia)-Its fine growth and thick glossy leaves, which glisten in the sunshine, makes it very handsome. The wood is said to be more valuable than the White Willow.

\begin{tabular}{|c|c|c|c|c|c|c|}
\hline Laurel & Leared & Willow- & Per 5 & Per 10 & Per $\mathbf{5 0}$ & Per 100 \\
\hline 3 to & 4 feet. & $\ldots \$ 0.20$ & $\$ 0.75$ & $\$ 1.25$ & $\$ 2.75$ & $\$ 5.00$ \\
\hline 4 to & 5 feet. & $\ldots \ldots$ & 1.00 & 1.75 & 4.00 & .50 \\
\hline 5 to & 6 feet. & $\ldots \ldots \ldots$ & 1.50 & 2.75 & 5.50 & 10.0 \\
\hline 6 to & 8 feet. & $\ldots$ & 2.25 & 4.00 & $\cdots \cdots$ & - \\
\hline 8 to & 10 & .75 & 3.25 & 6.00 & .... & \\
\hline
\end{tabular}

REGAL WTLOW (Salix Regalis)-A fine growing and hardy Willow. Said to be very desirable, but to us it is new, so cannot say much as to its good qualities yet.

Regal Willow- Each Per 5 Per 10 3 to 4 feet $\ldots \ldots \ldots \ldots \ldots \ldots \ldots \ldots \ldots \ldots \ldots \ldots 0.25 \quad \$ 1.00 \quad \$ 1.75$

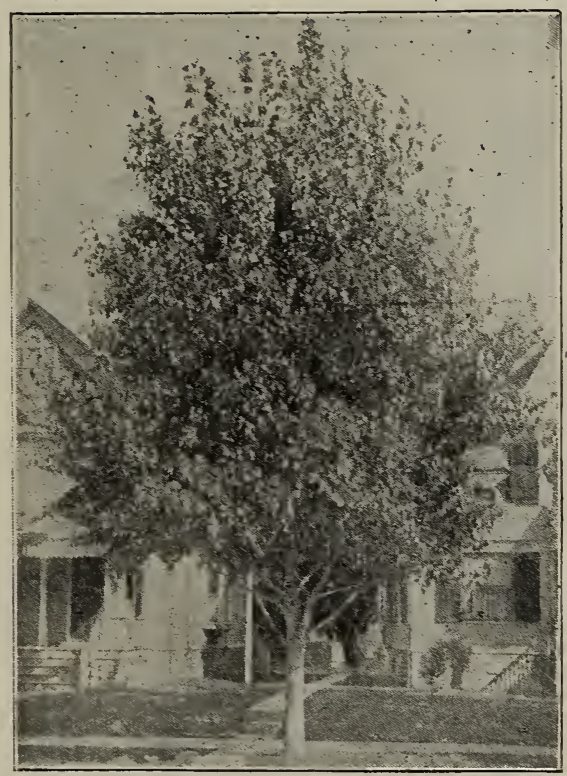

Carolina Poplar (See description page 1y)

DIAYOND WILLOW (Salix Cordata Vestita)-This is the variety that is used for posts. It is very desirable and lasting. It is a native along the Missouri River, where it thrives well. I think it will prove to be very profitable to grow for posts, if for no other purpose. The demand for it is increasing each year; does not grow to be very large, about 8 to 10 inches in diameter being its usual limit.

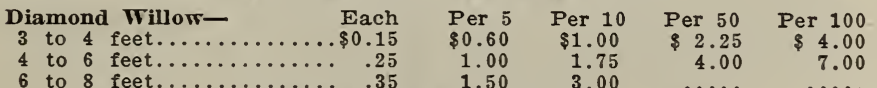

6 to 8 feet..................

AMERICAN LINDEN OR BASSWOOD (Tilla Americana)-A handsome lawn or shade tree. It is a native along the Missouri River bluffs near here; grows quite rapidly in moist situations. The blossom is very fragrant and sweet; desirable especially to bee keepers.

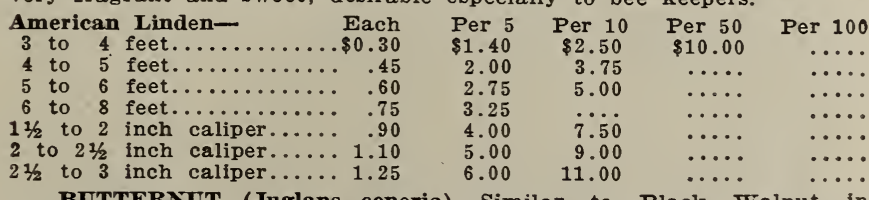

BUTTERNUT (Juglans ceneria)-Similar to Black Walnut in growth, foliage and nuts. The nuts, however, are oblong instead of round. Tree not quite so hardy in the West, wood valuable for post timber; a prolific bearer, quite desirable. 


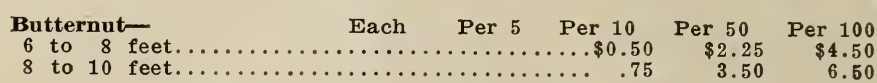

WILD BLACK CHERRY (Prunus Serotina)-Hardy, rapid grower; bears fruit abundantly when quite young. Its wood ranks next to Black Walnut in commercial value; very desirable for timber. Makes a handsome lawn tree. Bears white blossoms in raceimes in early spring, and ripens its abundant crop of fruit late in August. Fruit about the size of a large pea; valuable for the birds and some culinary uses.

\begin{tabular}{|c|c|c|c|c|c|c|}
\hline Wild & Black & Cherry- & Per 5 & Per 10 & Per 50 & Per 100 \\
\hline 3 to & 4 feet &.$\$ 0.15$ & $\$ 0.60$ & $\$ 1: 00$ & $\$ 2.00$ & $\$ 3.50$ \\
\hline 4 to & 5 feet & .25 & 1.00 & 1.75 & 3.00 & 5. \\
\hline 5 to & 6 feet & $t \ldots . .$. & 1.50 & 2.50 & 5.00 & 9.00 \\
\hline 6 to & 8 feet & $\ldots \ldots$ & 2.25 & 4.00 & . . . & - \\
\hline 8 to & 10 feet & t.......... .75 & 3.25 & 6.00 & . & \\
\hline 10 to & $12 \mathrm{fe}$ & t.......... 1.00 & 4.00 & 7.50 & . . . & 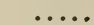 \\
\hline
\end{tabular}

BLACK WALNUT (Juglans Nigra)-Valuable to grown for nuts and timber. It is quite hardy here; succeeds best on a rich, deep, moist soil like bottom land. It grows a strong tap root, and it is hard to transplant the trees of any size, unless they have been transplanted or root-pruned when 1 year old. The 1 year seedlings transplant quite successfully.

All of these trees that I offer over 1 year old have been transplanted and have good-sized roots.

\begin{tabular}{|c|c|c|c|c|c|}
\hline Black & Walnut- & Per 5 & Per 10 & Per 50 & Per 100 \\
\hline 3 to & 4 feet........... $\$ 0.15$ & $\$ 0.60$ & $\$ 1.00$ & $\$ 3.00$ & $\$ 5.50$ \\
\hline 4 to & 5 feet............. & 1.00 & 1.75 & 5.00 & 9.00 \\
\hline 5 to & 6 feet............ & 1.75 & 3.00 & 6.50 & 12.00 \\
\hline 6 to & $\ldots \ldots \ldots \ldots$ & 2.25 & 4.00 & 8.00 & 15.00 \\
\hline 8 to & 10 feet. & 3.25 & 6.00 & $\ldots \ldots$ & $\ldots \ldots$ \\
\hline 2 to 3 & inch caliper...... 1.00 & $\cdots$ & $\cdots$ & $\cdots \cdots$ & $\ldots \ldots$ \\
\hline 3 to 4 & inch caliper....... 1.50 & $\ldots$ & $\ldots$ & $\ldots \ldots$ & .. \\
\hline
\end{tabular}

BURR OAK (Quercus Macrocarpa) - A native tree of spreading form; foliage deeply lobed and the largest and most beautiful among the oak leaves. The oaks when they attain size are among the most picturesque trees. The Burr Oak is rather slow in growth, but endures cold and drouth well. It is long-lived, durable and desirable as a variety in the lawn or yard.

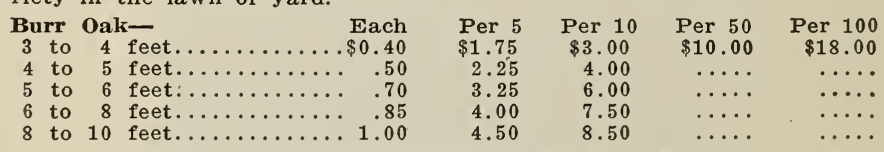

IRONWOOD OR HOP HORNBEAM (Ostrya Virginiana) - A small tree with thin bark and tough, hard wood; leaves ovate taper-pointed: fruit clusters resemble hops. A native in the gulches along the Missouri River and in the Black Hills. The tree is perfectly hardy in a cold climate. It holds its leaves nearly all winter, usually.

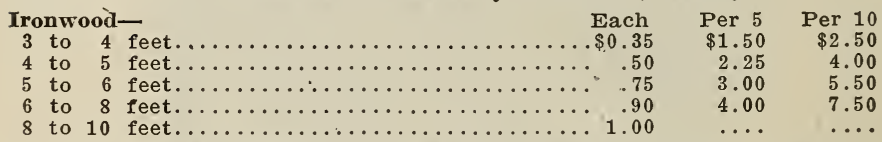

RUSSIAN MULBERRY (Morus Tartarica)-Moderately hardy, inclined to be short-lived and somewhat scrubby. It has some value in raising fruit to feed birds to keep them away from other fruits, and the fruit has also value for culinary purposes, if mixed with fruit having considerable tart; but alone it is rather insipid. This is the only Mulberry that has been successfully grown in this locality.

\begin{tabular}{|c|c|c|c|c|c|c|c|}
\hline \multicolumn{2}{|c|}{ Russian } & Mulberry- & Each & Per 5 & Per 10 & Per 50 & Per 100 \\
\hline 3 & to & feet....... &.$\$ 0.15$ & $\$ 0.60$ & $\$ 1.00$ & $\$ 2.00$ & $\$ 3.50$ \\
\hline 4 & to & feet.. & .20 & .90 & 1.50 & 3.00 & 5.00 \\
\hline 5 & to & feet. & .30 & 1.25 & 2.00 & 4.00 & 7.50 \\
\hline 6 & to & feet. & .40 & 1.75 & 3.00 & $\ldots \ldots$ & .... \\
\hline 8 & to 10 & feet..... & .55 & 2.50 & 4.50 & $\ldots \ldots$ & $\ldots \ldots$ \\
\hline
\end{tabular}

HORSE CHESTNUT, White-Flowering (Aesculus hippocastanum)Of handsome, regular form, ultimately reaching a large size. In May it is covered with large spikes of beautiful white flowers dotted with red and yellow. A beautiful tree for park and lawn when planted singly; for avenue planting it cannot be surpassed.

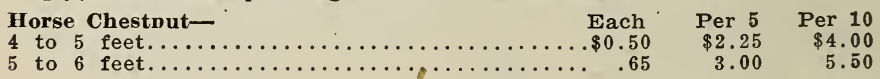

MAY DAY TREE-A very beautiful and desirable small growing tree bearing panicles of white flowers early in the season in great profusion. New and very desirable. Very hardy.

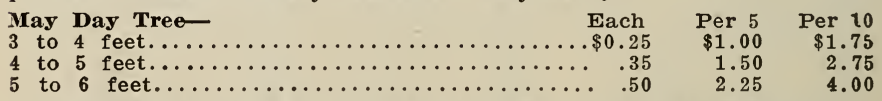

EUROPEAN ALDER (Alnus Glutinosa)-This tree is similar in appearance to the American Alder that is a native of Wisconsin, but it is more inclined to grow in tree form. It is a good grower and quite hardy here; handsome and desirable for a variety on the lawn. 


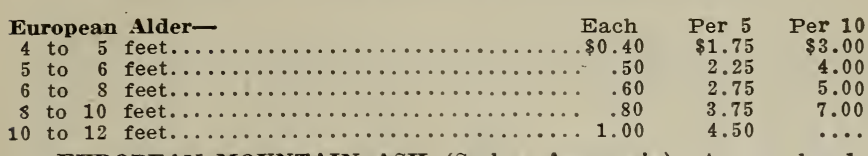

ECROPEAN MOUNTAIN ASH (Sorbus Aucuparia)-A very handsome lawn tree; bears clusters of red berries; quite hardy and desirable. Its worst fault is its tendency to sun-scald on the body. It is advisable to protect the south and west sides of the tree when small.

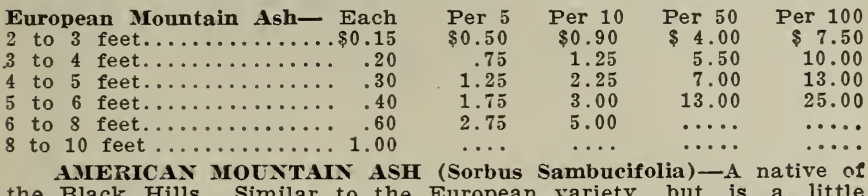
the Black Hills. Similar to the European variety, but is a little abundance. The fruit or berry of the Mountain Ash is of no value for food, but is very handsome in appearance.

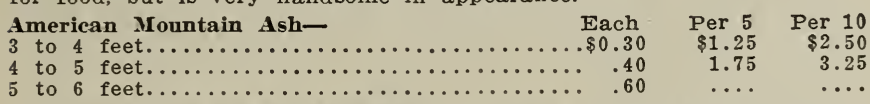

OAK LEAVED MOUNTAN ASH (Sorbus Hybrida Quercifolia)A hardy tree of fine pyramidal habit; height and breadth from 20 to 30 feet; leaf is deeply lobed similar to the leaf of the Burr Oak; $a$ very fine lawn tree.

Oak Leared Mountain Ash- Each Per 5 Per 10

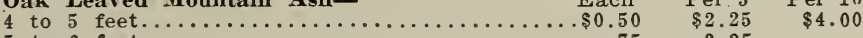

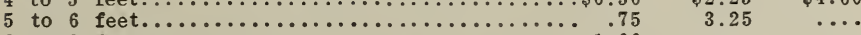

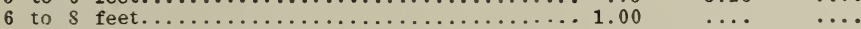

ENGLISH BUCKTHORN (Rhamnus Cathartica)-This is, we believe, the most valuable of all our deciduous trees for ornamental hedges, resisting well our cold, dry winters. Hardy anywhere in South Dakota. It is also a desirable tree for the lawn. It endures close pruning perfectly.

For prices see Hedge Seedlings.

EUROPEAN WHITE BIRCH (Betula Alba)-Its chalky white bark and beautiful foliage make it a desirable lawn tree. Very hardy where the ground is not too dry for it; a shallow rooting tree, as, in fact. all of the birches are. Will stand almost any amount of cold, if not too dry.

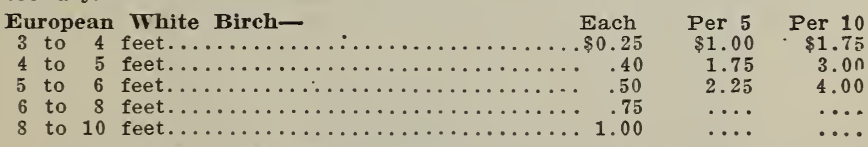

PAPER OR CANOE BIRCH (Betula Papyrifera)-A native of the Black Hills. It very much resembles the European variety, but has a larger leaf and is a stronger grower, and, I think, much more desirable for this section at least.

\begin{tabular}{|c|c|c|c|c|c|c|c|}
\hline $\mathrm{Ca}$ & aoe & Birch- & Each & Per 5 & Per 10 & Per 50 & Per 100 \\
\hline 3 & to & 4 feet. &.$\$ 0.30$ & $\$ 1.25$ & $\$ 2.00$ & $\$ 5.50$ & $\$ 10.00$ \\
\hline 4 & to & 5 feet. & $\ldots \ldots \ldots \ldots$ & 1.75 & 3.00 & 8.00 & 15.00 \\
\hline 5 & to & 6 feet. & $\ldots$ & 2.25 & 4.00 & $\ldots \ldots$ & $\cdots$ \\
\hline 6 & to & 8 feet. & $\ldots \ldots \ldots \ldots \ldots$ & 3.25 & 6.00 & $\ldots \ldots$ & $\ldots$ \\
\hline 8 & to & 10 feet & $\ldots \ldots \ldots \ldots \ldots 1.00$ & $\ldots$ & $\cdots$ & $\cdots \cdots$ & $\cdots$ \\
\hline
\end{tabular}

RUSSLAN OLIVE (Eleagnus Angustifolia) - A very hardy and quite a rapid growing tree with a silvery foliage; very striking in appearance. Its ability to endure extreme cold and drouth makes it desirable for ornamenting lawns and for hedges. It has a small, yellow blossom in early spring which is very fragrant indeed. Its fruit is of no food value to speak of, but hogs seem to be fond of it. It is a. silvery color about the size of a common bean, about one-half of which is hard seed. The pulp is of a dry, sweetish nature and is of no culinary use. The wood is of poor quality. The tree, I think, is rather short-lived and not large.

\begin{tabular}{|c|c|c|c|c|c|}
\hline Russian & Olive- & Per 5 & Per 10 & Per 50 & Per 100 \\
\hline 3 to 4 & 4 feet.... & $\$ 1.00$ & $\$ 1.75$ & $\$ 5.00$ & $\$ 9.00$ \\
\hline 4 to & feet.......... & 1.50 & 2.50 & 6.50 & 12.00 \\
\hline 5 to & feet............ & 2.25 & 4.00 & $\cdots \cdots$ & $\cdots$ \\
\hline 6 to & 8 feet............. & 3.00 & 5.50 & $\cdots \cdots$ & $\cdots$ \\
\hline 8 to 10 & 0 feet.......... 1.00 & 3.75 & 7.00 & $\cdots \cdots$ & $\cdots$ \\
\hline 10 to 12 & 2 feet... & 5.00 & $\cdots$ & $\therefore \cdots$ & - \\
\hline $1 \frac{1}{2}$ to 2 & 2 inch caliper..... 1.50 & $\cdots$ & $\cdots$ & $\cdots \cdots$ & • \\
\hline 2 to 3 & caliper... & $\cdots$ & $\cdots$ & ..... & \\
\hline
\end{tabular}

SIBERIAN PEA TREE (Caragana Arborescens)-An extremely hardy shrub or low tree originally from Siberia. Is valuable for hedges or for an ornamental tree, especially in the north part of the state and North Dakota; has a sharp thorn. Its seed are said to be valuable for poultry and culinary uses. Its leaves furnish a blue dye, and they resemble the leaves of the Locust somewhat. We have not had it long enough to test its real value, but it is now enjoying a rea boom. This is what so mariy fake agents have represented to have 
ERRATUA

ERRATCI. Each, per 5, per 10 .
Prices on Butternut should read: Each 
sold to the farmers throughout the country, and in most cases they have delivered Osage Orange 'or some other cheap or worthless plant.

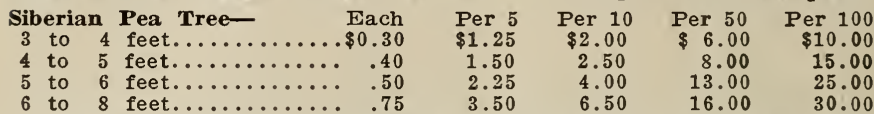

TREE OF HEAVTN (Ailanthus Glandulosa)-This Chinese tree is not sufficiently hardy to withstand our climate perfectly. It kills back nearly to the ground most winters, if in an exposed location, but it produces a pleasing effect, if cut to the ground each spring and allowed to grow up. The one year's growth makes a fine large tropical appearing plant of 6 to 10 feet in height with large leaves (sometimes 3 feet or more in length) similar to the leaves of the Sumac.

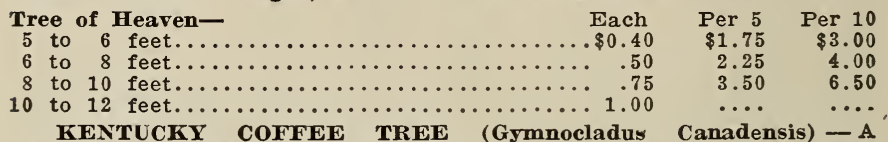
medium sized tree with rough, scaly bark. Very hard wood, large compound leaves and large seed pods similar to those of the Honey Locust; a handsome and valuable tree. It is found native in the extreme southeastern part of South Dakota. It is very hardy, but of rather slow growth.

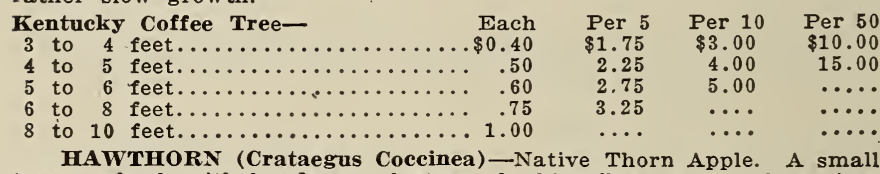
tree or shrub with handsome clusters of white flowers in early spring, followed by small red fruit ( $1 / 4$ to $1 / 2$ inch in diameter) which hangs on the tree until late in autumn. Makes a very desirable hardy tree for the lawn.

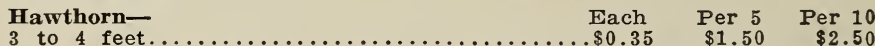
3 to 4 feet................................

\section{WEEPING TREES}

WEeping MOUNTAIN ASH (Serbus Aucuparia Pendula)-A strong grower and remarkably pendant; very striking; the most hardy weeper for the North. Each, 75 cents.

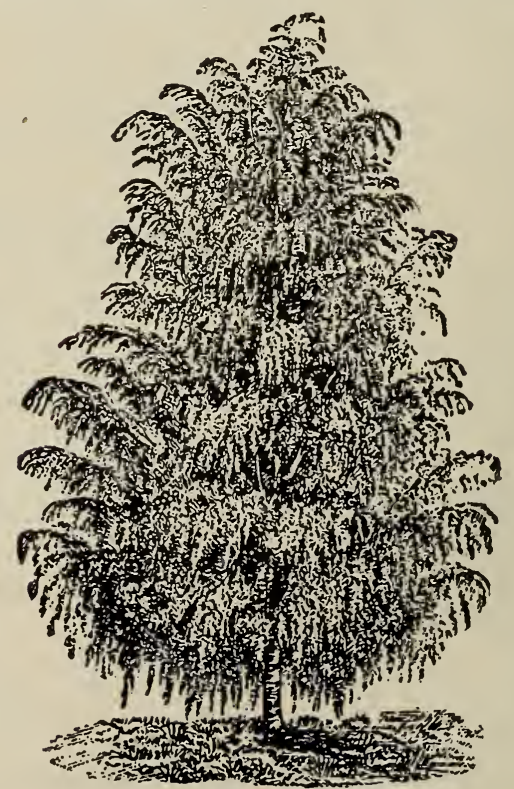

Cut Leaved Weeping Birch

CUT LEAVED WEEPING BIRCH (Betula Alba Pendula Lacinata) -Erect, stately, a rapid grower and hardy, with long fine pendant branches and delicately cut leaves; the trunk is very white, and it is elegant for lawns and cemeteries. Four to five feet, each $\$ 1.00 ; 5$ to 6 feet, each $\$ 1.25 ; 6$ to 8 feet. each $\$ 1.50$. 
WISCONSIN WEEPING WILLOW-A rapid growing, moderately hardy tree. Very handsome and desirable for moist places.

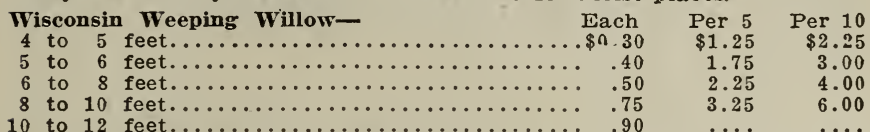

THURLOW WEEPING WILLOW-This is a new and very desirable sort, according to present indications. It is a very strong grower and apparently quite hardy here. The main stem grows very straight and upight, while the long slender branches droop gracefully, giving it a triumphant, victorious appearance.

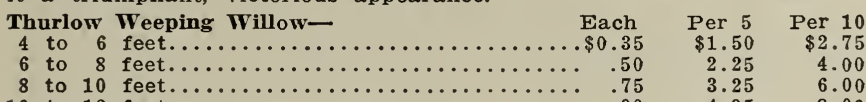

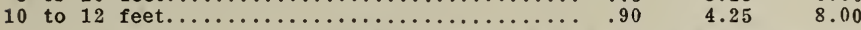

PENDAHTA WEEPING WHLOW-A strong growing variety. In habit of growth it is between the Wisconsin and Therlow varieties. Quite hardy.

Pendahta Weeping Willow- Each Per 5 Per 10

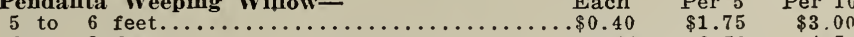

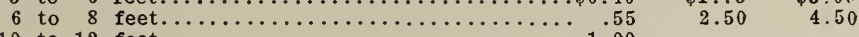

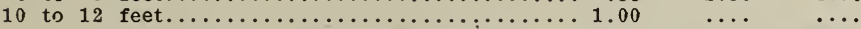

NIOBE WEEPING WILLOW-Imported by Prof. N. E. Fansen, who gave it the name. It is a golden barked White Willow if a decided weeping habit. It is extremely hardy and for this ruason will. we think, be of especial value in the Northwest where we are badly in need of a strictly hardy weeping willow. I offer it this season for the first time and have great hopes for it.

Niobe Weeping Willow-

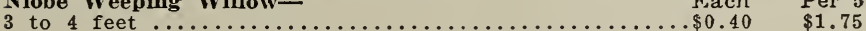

\section{EVERGREENS}

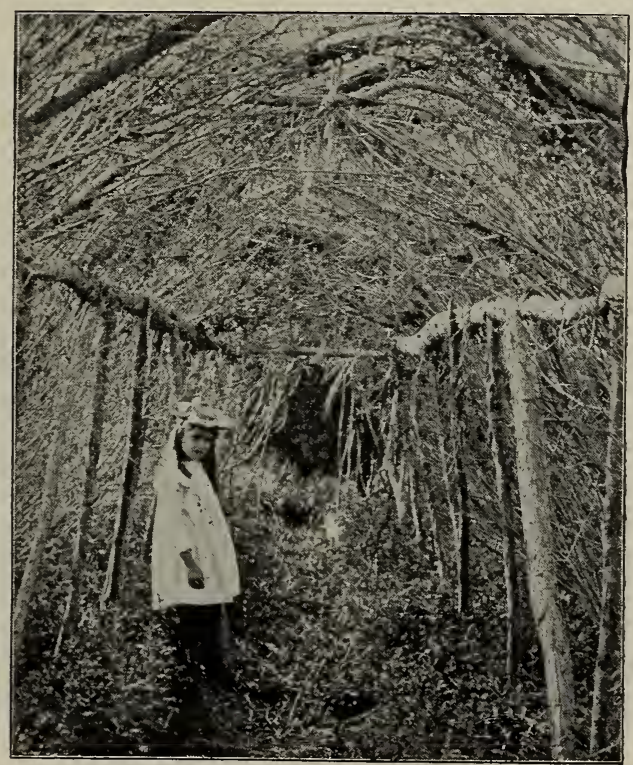

Evergreen Shade Bower.

Evergreens are my Fad. I have always had a warm place in my heart for a nice, shapely tree of this class, and I think, comparatively speaking, that I have been very successful with them, and am in a position at present to supply you as well as any one in the Northwest with varieties peculiarly adapted to this locality. My experience has taught me what to plant and what not to plant. My supply this year is much better than ever before. A number of worthless varieties '(for this section) have been dropped from my list. 
Caution-When the trees are received from the nursery, don't open them or let the air get to the roots until you are ready to wet them and place them in moist earth immediately. Don't wet the foliage and leave them packed in that condition to heat and rot off.

Planting-It is very essential to pack the earth very solid about the roots and water well if the ground is very dry. Keep the surface soil perfectly mellow by cultivation or mulch heavily with old hay; avoid bright straw, as it reflects the rays of the sun and burns the foliage.

The principal causes of failure are: First, the trees are dead when received from the nursery. Second, they are improperly handled after they are received. You must absolutely prevent the drying of roots and plant so trees will not move around after they are planted. Large trees should be staked.

Notice-My complete list of sizes ( 8 to 12 and 12 to 18 inches) just right for farmers to plant in quantity for shelter belts around farm buildings. There is nothing that will beat evergreens for this purpose. I list here only transplanted trees. If seedlings are wanted, write for prices.

\section{JUNIPERS}

RED CEDAR (Juniperas Virginiana) - A very hardy, rugged native It grows rapidly and responds well to good cultivation and care, but it will also hang on and live under the most adverse conditions. It will live on the highest, dryest hills in our State when once established, although the growth in this case is slow. It can be sheared into almost any conceivable form. In fact, it will adapt itself to any condition. For a lasting, serviceable shelter belt for this section. it is hard to beat. Its recent tendency to blight and rust is causing some alarm. Don't plant it near the orchard.

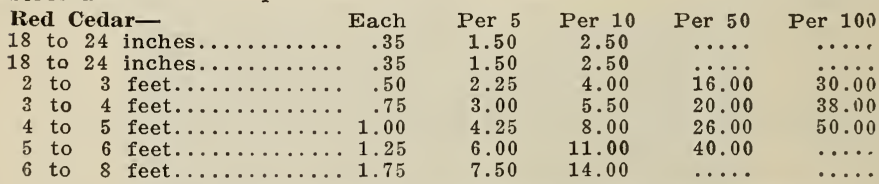

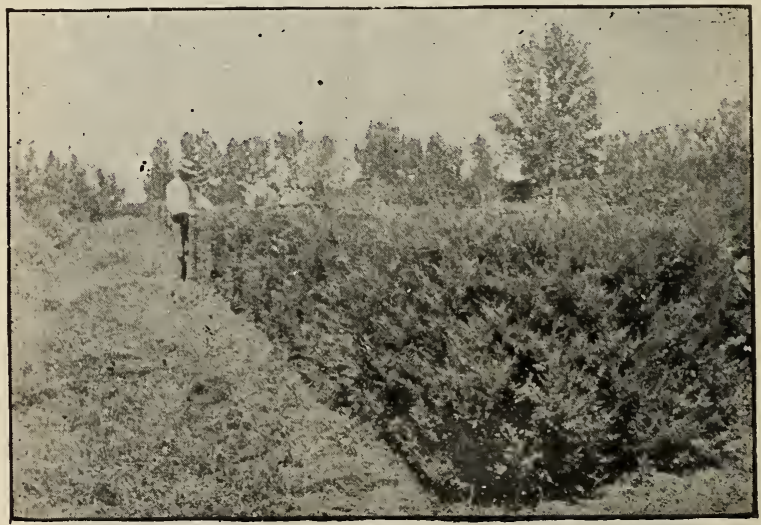

Red Cedar Hedge, 4 Years from Planting.

TRAILING JUNIPER (Juniperas Communis)-This is a native of the Black Hills; of spreading habit. In fact, it does not grow up in tree form, but after it gets up 2 or 3 feet high. lops over on the ground all around, and its growth only increases its breadth and circumference. The terminal branches are always inclined upward, therefore if it is trimmed in a round form, it makes the most beautiful saucer-shaped specimen for the lawn imaginable. It also makes one of the most delicate, beautiful little hedges.

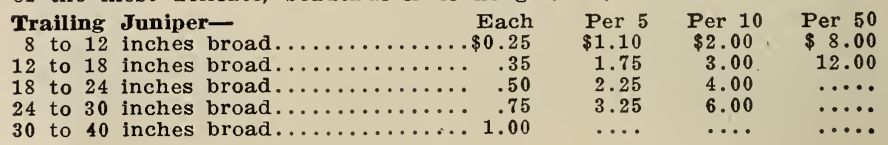


CREEPING JUNIPER (Juniperas Sabina Procumbens) - A prostrate or creeping evergreen shrub similar to the Trailing Juniper, in habit of growth, but hugs the ground closer. The leaves are awl-shaped. loose and scale-like. Valuable for low hedging and covering steep hillsides. Also valuable for a variety on the lawn.

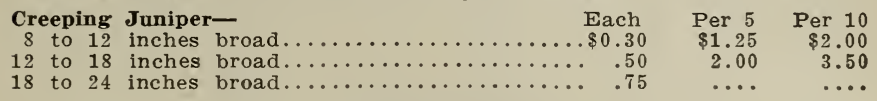

\section{PINES}

AUSTRIAN PINE (Pinus Austrica)-Similar to the Scotch; a stocky, rapid grower. Leaves long, stiff and dark green and more erect than the Scotch; foliage sun-burns considerably when tree is small. but endures better as it gets larger. Rather handsome and fine form: ed. A much better and more lasting tree than the Scotch.

\begin{tabular}{|c|c|c|c|c|c|c|c|}
\hline \multicolumn{2}{|c|}{ Austrian } & Pine- & Each & Per 5 & Per 10 & Per 50 & Per 100 \\
\hline & & inches. &.$\$ 0.20$ & $\$ 0.75$ & $\$ 1.25$ & $\$ 5.00$ & $\$ 9.00$ \\
\hline 12 & to 18 & inches. & .25 & 1.00 & 1.75 & 8.00 & 15.00 \\
\hline 18 & to 24 & inches. & .35 & 1.50 & 2.75 & 10.00 & 19.00 \\
\hline 2 & to 3 & feet. & .50 & 2. & 4.00 & 15.00 & 28.00 \\
\hline 3 & to & feet. & .60 & & 5.00 & ..... & $\cdots$ \\
\hline 4 & to & feet. & .75 & 3. & 6. & $\ldots$ & .. \\
\hline 5 & to & feet. & . 1.00 & 4.25 & 8.00 & • & . \\
\hline 6 & to 8 & feet. & .1 .50 & & & & e \\
\hline
\end{tabular}

PONDERosa, Westery Yellow OR BULL PINE (Pinus Ponderosa)-A native of the Black Hills and the Rocky Mountains. A strong. stocky and rapid grower. There is probably no pine in existence that requires so little moisture or that will thrive so well on high. dry, exposed situations. At about the age when the Scotch Pine falls. the Ponderosa Pine begins to show its value. It is very hard to transplant the small trees from the woods, but nursery grown trees (such as we offer) that have been transplanted at one-year-old, handle quite successfully.

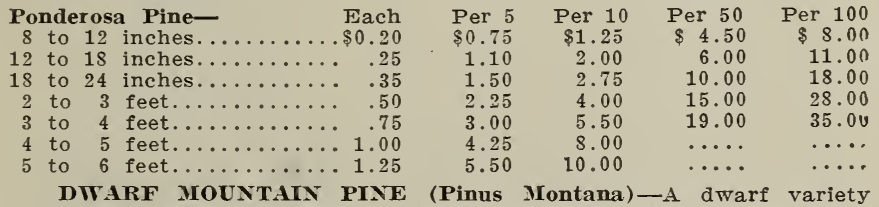

DWARF MOUNTAT PIYE (Pinus Montana)-A dwarf variety for planting in lawns and cemeteries; hardy and handsome; very bright green foliage. It can hardly be called a tree, as it only grows to a height of a few feet, and usually its breadth is as great, or greater than its height.

Dwarf Mountain Pine- Each Per 5 Per 10 Per 50 Per 100 $11 / 2$ to 2 feet............ $\$ 0.40 \quad \$ 1.75 \quad \$ 3.00 \quad \ldots \ldots .6$

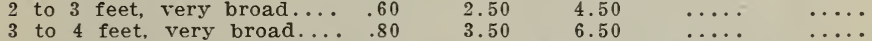

JACK PINE (Banksian Pine)-An unusually rapid grower, making two or three growths or joints each year, where other pines make but one. It is also very hardy, and will do well on very poor soils. In all, it is a very desirable variety, although not very ornamental A very valuable tree in sandy poor soils where nothing else will succeed. Jack Pine- Each Per 5 Per 10 Per 50 Per 100

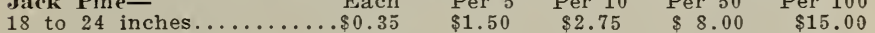

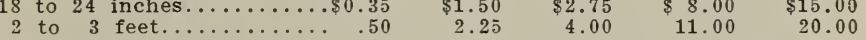
3 to 4 feet.......................... 4 to 5 feet............... $75 \quad 3.25 \quad 6.00 \quad \ldots \ldots$ 5 to 6 feet....................

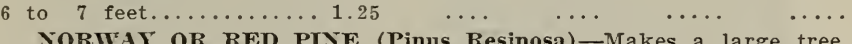

NORWAY OR RED PINE (Pinus Resinosa)-Makes a large tree. Needles often 5 to 6 inches long; wood hard and compact; a good grower and hardy.

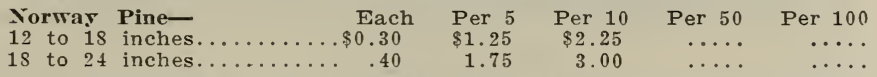

18 to 24 inches................ growing sort. Makes a good shelter belt, but it is not extremely handsome, though quite popular.

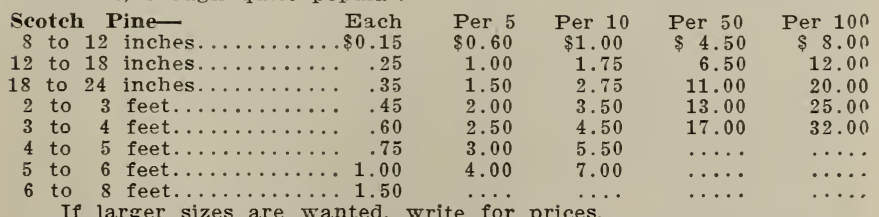

If larger sizes are wanted, write for prices.

WHITE PINE (Pinus Strobus)-This is the lumber pine of Wisconsin and Minnesota; rather slow of growth when young, but as it attains age. grows very rapidly. It has a snft delicate foliage, and is very graceful in appearance and very valuable where it succeeds well. but it is not quite at home on the open Western prairies. 


\begin{tabular}{|c|c|c|c|c|c|c|c|}
\hline & ite & $\mathbf{P i}$ & Each & Per 5 & Per 10 & Per 50 & Per 100 \\
\hline 12 & to & 18 & inches... & $\$ 1.25$ & $\$ 2.25$ & $\$ 8.00$ & $\$ 15.00$ \\
\hline 18 & to & 24 & inches........... & 1.75 & 3.00 & 11.00 & 20.00 \\
\hline 2 & to & 3 & 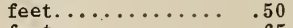 & 2.25 & 4.00 & 16.00 & $\ldots \ldots$ \\
\hline 3 & to & 4 & feet............ & 3.00 & 5.50 & .... & - \\
\hline 4 & to & 5 & feet............ & $\cdots$ & $\cdots$ & $\cdots \cdots$ & $\cdots$ \\
\hline 5 & to & 6 & feet........... 1.25 & ... & $\cdots$ & $\cdots \cdots$ & $\cdots$ \\
\hline 6 & to & 7 & $\ldots \ldots \ldots \ldots 1.50$ & - $\cdots$ & $\cdots$ & $\cdots \cdots$ & $\cdots \cdots$ \\
\hline
\end{tabular}

\section{SPRUCES}

The Spruces are among the most beautiful evergreens for general planting on lawns and for hedges and screens, and are very easily transplanted.

AMERICAN WHITE SPRUCE (Picea Alba)-A very handsome variety of rather fast growth. A native from the Eastern States west into Minnesota and is very well-known. Of straight, upright growth and symmetrical form; very hardy and desirable.

American White Spruce- Each
12 ot 18 inches...... Per 5

BLACK HILLS SPRUCE (Picea Nlba)-This is botanically classed the same as the American White, but, having grown in the Black Hills region for so many generations, it has changed to such an extent as to give it the appearance of being a different variety. It is a little slower in growth, more stocky and sturdy, the needles are larger. stiffer and of a darker color, and the tree is more compact than the Eastern White spruce. It is admirably equipped for the Western prairies, easly transplanted, and altogether, it is very desirable for the general planter.

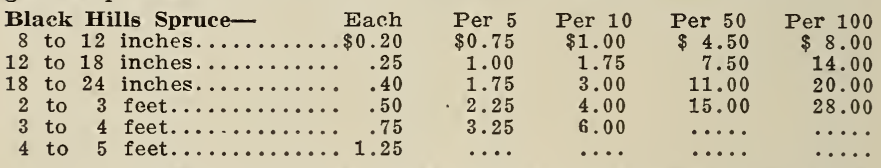

We have some very fine blue specimens of the Black Hills Spruce, that we will sell 50 per cent higher than the above quoted prices, if desired. That is, if an average green specimen costs 50 cents, a selected blue one will cost 75 cents.

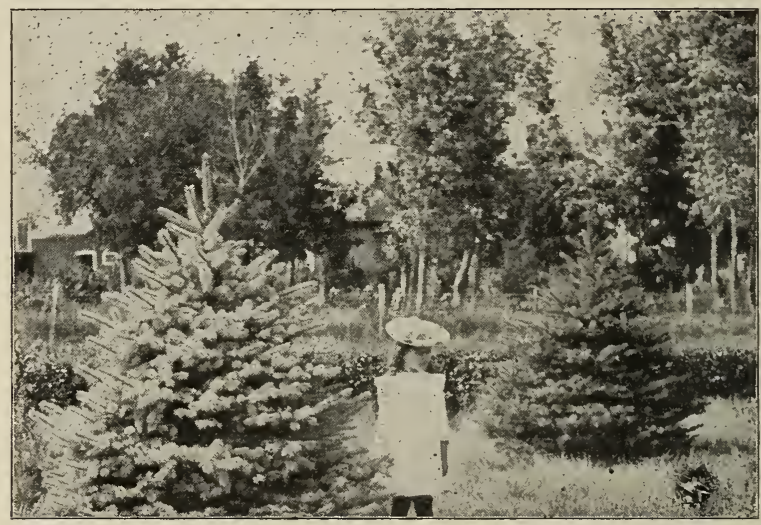

Colorado Blue Spruce

COLORADO BLUE SPRUCE (Picea Pungens)-It is extremely hardy and endures well the sun and drying winds; very compact and symmetrical in form. The needle is a little larger than that of the White Spruce and very sharp pointed, and varies in color from a delightful green to a deep blue. Only a small portion of the seedlings are real blue, hence we have to charge a higher price for the blue specimens. They are very attractive and satisfactory.

\begin{tabular}{|c|c|c|c|c|c|}
\hline Blue & Specimens- & Per 5 & Per 10 & Per 50 & Per 100 \\
\hline 8 to & 12 inches.. & $\$ 1.75$ & $\$ 3.00$ & $\ldots \ldots$ & $\ldots \ldots$ \\
\hline 12 to & 18 inches.... & 3.75 & 7.00 & $\cdots \cdots$ & $\ldots \ldots$ \\
\hline 18 to & 24 inches........ & $\cdots$ & ... & .... & $\ldots \ldots$ \\
\hline 24 to & 30 inches........ & $\cdots$ & $\cdots$ & $\cdots \cdots$ & $\cdots \cdots$ \\
\hline Greer & a Specimens- & Per 5 & Per 10 & Per 50 & Per 100 \\
\hline 8 to & 12 inches. & $\$ 0.90$ & $\$ 1.50$ & $\$ 7.00$ & $\$ 13.00$ \\
\hline 12 to & 18 inches. & 1.50 & 2.75 & $\cdots \cdots$ & $\cdots \cdots$ \\
\hline 18 to & 24 inches.......... .50 & 2.25 & 4.00 & $\cdots \cdots$ & $\cdots \cdots$ \\
\hline 24 to & 30 inches............ .70 & 3.00 & . & .... & .... \\
\hline
\end{tabular}


CONCOLOR SPRUCE (Ables Concolor)-A very delicate and beautiful evergreen; a native of Colorado; a pyramidal, upright grower. It has a silvery green foliage different from any other evergreen we have. It is a rarity in this vicinity, and it appears to be hardy so far.

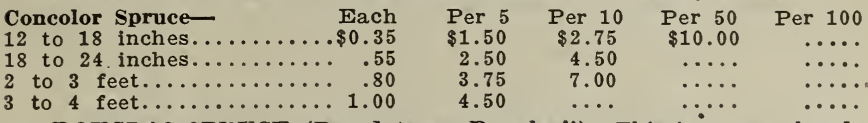

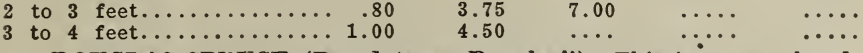

DoUgLAS SPRUCE (Pseudotsuga Douglasii)-This is a very handsome, upright growing tree of symmetrical form; moderately hardy: valuable for variety. You should surely have one or more of these beautiful trees.

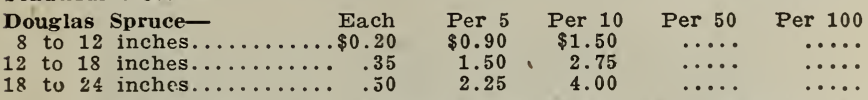

NORWAY SPRUCE (Picea Excelsa)-This is a very finely formed and strong growing tree, and, where the climate is congenial to it, one of the most valuable sorts. It is not quite at home in this section, and I have almost quit propagating it, but have a small supply yet in strick.

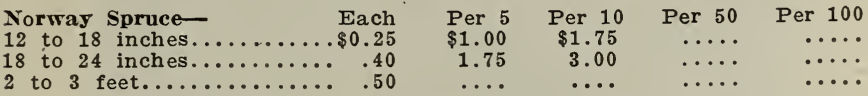

2 to 3 feet............... $50 \quad \ldots . . .$.

We have a good stock of large evergreens, but we do not in general recommend planting those that are over 6 feet

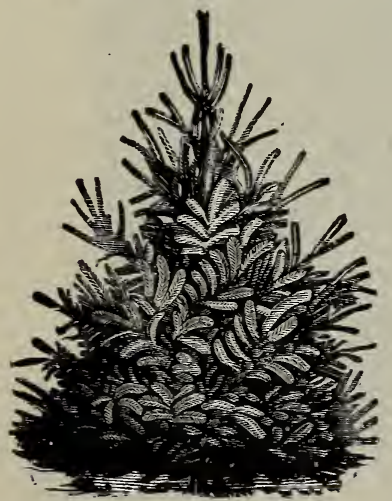
high unless at least a portion of the earth can be retained on the roots. If you wish larger sizes than listed, write for prices.

We deliver them to farmers who come right to the nursery, by placing in a small box with the dirt adhering to them. We also ship them in this way to parties that are willing to pay the freight. We also get out some in the winter when the ground is frozen, with a ball of earth attached therto sometimes weighing 1,000 pounds each: trees as large as 9 or 10 feet high and they almost invariably grow. Of course this is more expensive, but it usually pays. If you are interested, write us.

\section{OUR METHOD OF HANDLING EVERGREENS.}

Various methods have been practiced to retain the soil around the roots of evergreens to insure the safe transplanting of them. We have tried all sorts of methods, but the one we have found safest, cheapest and most effectual is to sew burlap tightly around the ball of earth that is taken up with them in such a way as to hold it intact. Trees taken up in this way can be planted without removing the burlap, which will soon rot away in the ground, and does no harm. We make an additional charge for this, above catalogue prices, as follows:

Trees-12 to 18 inches high ....................... each

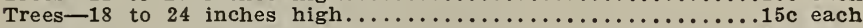

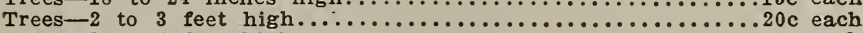

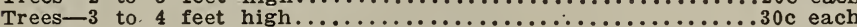

Larger sizes in proportion. This is much cheaper and better than shipping in boxes, tubs or baskets.

EUROPEAN LARCH (Larix Decidua)-A rapid growing deciduous Conifer resembling an evergreen, when in leaf, but it sheds its leaves in the autumn. It is a very graceful lawn tree, but this is about the Northwestern limit of its hardiness. The Larch must be planted very early in the spring before the leaves start.

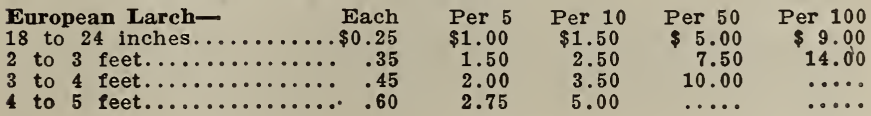




\section{LILACS}

COMMON WHITE (Syringa Vulgaris Alba)-A stocky; strong grower, and exceedingly hardy. The bloom is in large white clusters, and very fragrant. Thrives well nearly everywhere. 2 to 3 feet, 20 cents; 3 to 4 feet, 30 cents; large clumps, 50 cents.

sin:

COMMON PURPLE (Syringa Vulgaris)-Similar to the White, except that the twigs are a little more slender, and the bloom is a pinkish purple color; a more profuse bloomer. Price each, 2 to 3 feet, 20 cents; 3 to 4 feet, 30 cents; large clumps, 50 cents.

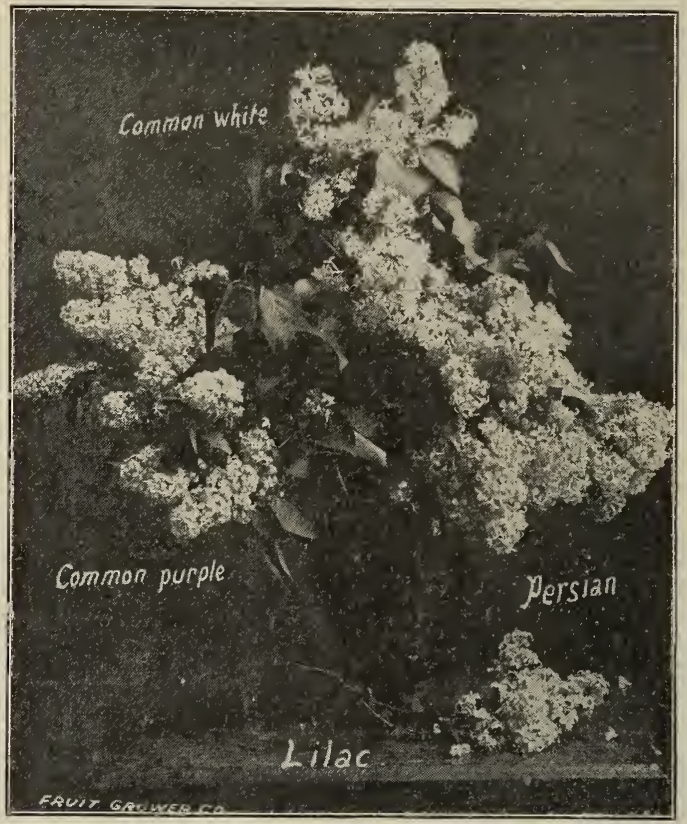

PERsian LILAC (Syringa Persica)-A native of Persia, not quite so hardy as the common, but a more rapid grower. The branches are long and slender, the leaf small, and it blooms in great profusion on the terminal branches. Strong plants, each, 25 cents; large clumps, 50 cents.

JAPAN TREE LILAC (Syringa Japonica)-A native of northern Japan. It is perhaps not quite so hardy as the common, but it is hardy enough here; a tree lilac that does not sprout from the root. and will attain a height of 20 feet. The immense panacles of white blossoms appear late in the season. It is very desirable. Price, 4 to 5 feet, each 50 cents.

CHINESE TREA LILAC-A strong grower; quite hardy; sweet scented and very desirable. Blooms in June. 2 to 3 feet, each 25 cents: 3 to 4 feet, each 35 cents.

\section{HONEYSUCKLES}

WHITE BUSH HONEY SUCKLE (Lonicera Tartarica Alba)-A strong, vigorous growing shrub, perfectly hardy; has a profusion of small, white blossoms, last of May, which are followed by bright, waxy red berries the size of a common currant, which ripen in the fall and hang on late; very handsome, but not edible fruit. Price, each, 2 to 3 feet, 20 cents; 3 to 4 feet, 30 cents; 4 to 5 feet, 40 cents; 5 to 6 feet. 50 cents.

PINK HONEY SUCKLE (Lonicera Tartarica Rosea)-Similar to the White, except that it is not so strong and vigorous, and not quite so good a bloomer; red berried. Price, each, 2 to 3 feet, 25 cents; 3 to 4 feet, 35 cents; 4 to 6 feet, 50 cents.

DISCOLOR HONEY SUCKLE (Lonicera Tartarica Discolor)-A hardy, strong grower, and very profuse bloomer. Flowers are large. rose pink or red; berries are bright yellow; very showy. Price, 2 to 3 feet, each, 25 cents; 3 to 4 feet, each, 35 .cents; 4 to 5 feet, each, 50 cents. 


\section{SPIREAS}

ANTHONY WATERER-A small, dwarfish grower, 15 to 18 inches high, and is covered the entire season with large umbels of deep pink flowers. Quite hardy here, and very desirable. Each, 30 cents.

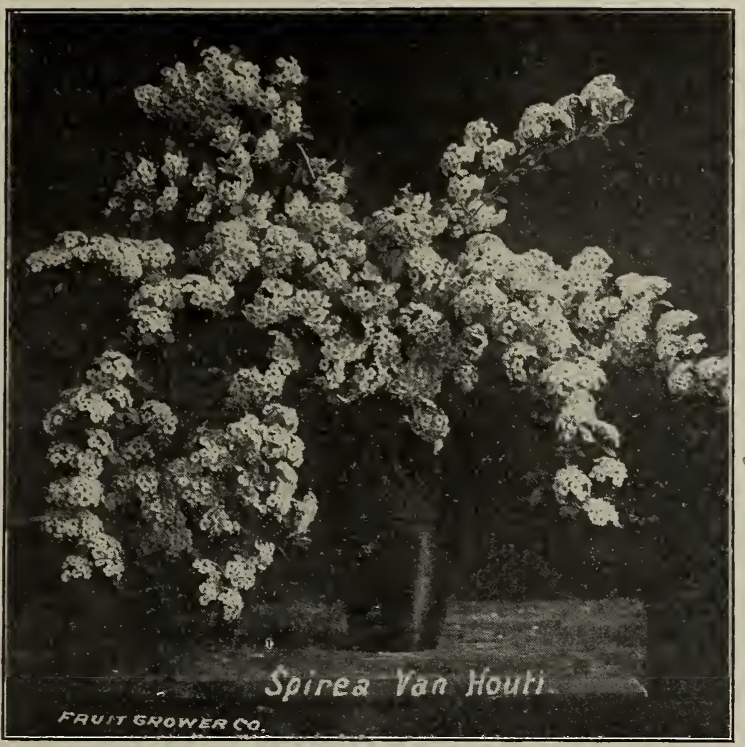

BLLARDI-Tall growing with plume-like spikes of deep rosecolored flowers. See cut. 2 to 3 feet, each 20 cents; 3 to 4 feet, each 30 cents.

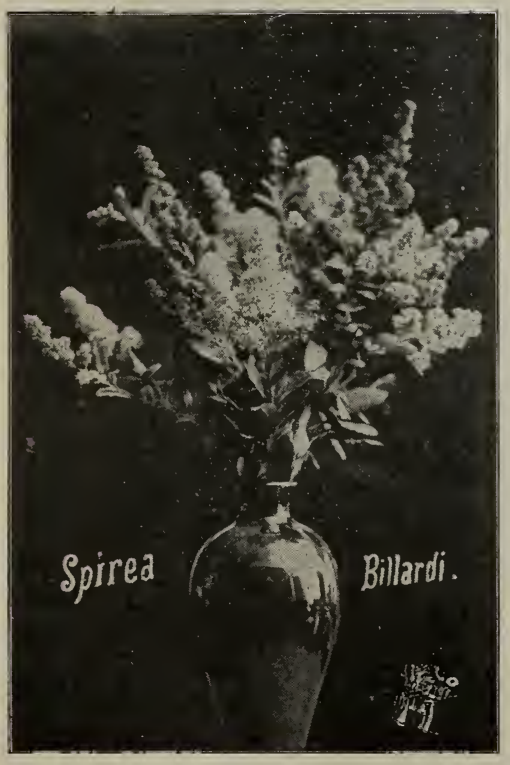

GOLDEN-A rapid grower and perfectly hardy. Bears a profusion of bloom in small clusters. White. with numerous brown specks; very handsome. 3 to 4 feet, each, 25 cents; 4 to 6 feet, each, 40 cents.

PRUNHFOLIA - A very beautiful variety; flowers white and very double; very profuse bloomer in May; foliage turns a very beautiful brown color in autumn; quite hardy here and desirable. 2 to 3 feet, each, 25 cents; 3 to 4 feet, 35 cents.

VAN HOUTI-The grand est of the Spireas; perfectly hardy, a strong grower, and a profuse bloomer. Has a small, delicate, white blossom borne in clusters that almost entirely cover the bush about June 1st; very handsome. even when not in bloom. Price, 2 to 3 feet, 20 cents each; 3 to 4 feet, 30 cents: 4 to $5 \mathrm{ft}$., 40 cents. Specia price on larger quantities.

SORBIFOLIA (Ash Leaved Spirea) - A vigorous growing bush with large handsome foliage resembling that of the Mountain Ash. Long spikes of white flowers in July. A very desirable acquisition to the list. 2 to 3 feet, each 30 cents. 


\section{Miscellaneous Shrubs}

AMERICAN WAHOO OR STRAWBERRY TREE (Enonymus Atropurpureus) - An extremely hardy and beautiful native shrub, bearing a delicate, small, reddish-brown blossom in a profusion of clusters about June 1st, and is followed by three-cornered pink berries in the fall that ordinarily remain on all winter. Each, 2 to 3 feet, 20 cents; 3 to 4 feet, 30 cents; large clump, 50 cents.

FLOWERING ALMoND (Amygdalus Nana)-A very hardy and good growing shrub. A small, double flower, resembling a small rose blooms in May or early part of June; a profuse bloomer. We have both the double white and double pink. State color preferred. Each, 25 cents.

PURPLe LeAVed BARBerRy (Berberis Purpurea)-An interesting variety of the common Berberry. When planted in the full sunlight, the leaves are a deep purple color. Bears an edible fruit. Very desirable and easy to make live. Each, 25 cents.

JAPANESE BARBERRY (Berberis Thunbergii)-A native of Japan. It is quite hardy here, but I would not recommend it much north of this only in sheltered localities. Its low, very dense habit, attractive red fruit and scarlet fall coloring of leaves, makes it very desirable for dwarf hedges and borders.

Japanese Barberry- Each Per 5 Per 10 Per 50

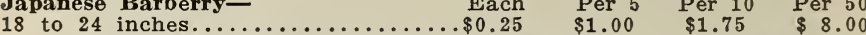

PHULADELPHUS. MOCK ORANGE, SYRINGA-A dwarfish shrub flowers smaller than the single variety, but very double and desirable hardy. Each, 25 cents.

TAMARIX AMURENSIS-This is a very beautiful, hardy and rapid growing shrub. Its leaves very much resemble those of the Juniper or Cedar, except that it is deciduous. It bears a very delicate pinkish white flower, and continues blooming all through the summer. Fine for hedging or screens. 3 to 4 feet, each, 20 cents; 4 to 6 feet, each, 30 cents. For cuttings see Cutting Department, page 17.

RUSSIAN ARTEMESIA-This is a strong and vigorous type of the shrub commonly known as "Old Man." It is larger and more rapid in growth, often making a growth of 6 feet from the cuttings the first year. Desirable for low hedges, for screens or cuttings or wind-breaks. It stands remarkably extreme. douth and cold. Each, 20 cents. For cuttings, see Cutting Department, page 17

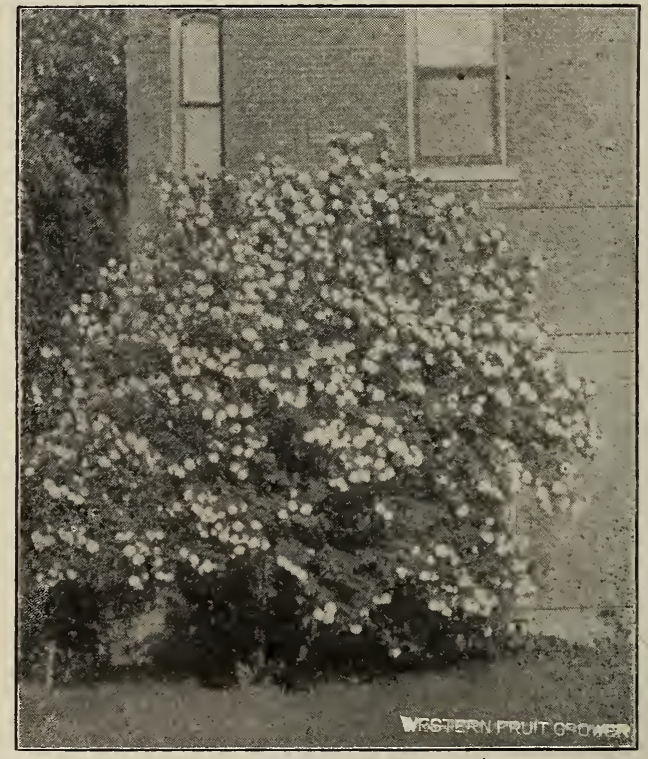

Snowball

SNOWBALL (Vibernum Sterilis)-A hardy, well-known showy shrub. Attains a height of 8 or 10 feet. Produces its snowy white flowers in large balls or masses in June. Each, 2 to 3 feet, 25 cents: 3 to 4 feet, 35 cents; 4 to 6 feet, 50 cents.

RED OSIER DOGWOOD (Cornus Stolonifera)-A desirable and hardy strong growing native shrub; grows to - height of 10 or 12 feet Its bright red bark and delicate foliage make it beautiful both winter and summer. It is covered with delicate clusters of white flowers in summer, followed by white, waxy berries, which stay on till hard frost comes in the fall. 2 to 3 feet, each, 20 cents; 3 to 5 leet, each, 30 cents. 
HIGH BUSH CRANBERRY, "ihernum Opulus)-A native shrub or small tree, resembling the cummcn snuwiall in leaf and growth of branches. The large white, flat clusters of flowers in early spring are followed by bright red acid berries in the autumn, make it attractive all through the season. The fruit is also valuable for culinary uses; makes an excellent jelly. Strong. stocky plants, each, 35 cents.

HYDRANGEA (Panieulata Grandiflora)-Large flowered Hydrangea, hardy. A fine shrub, growing from 6 to 8 feet high. Flowers white in large pyramidal panicles 8 to 12 inches long, and produced in August and September. Good, strong plants, each, 30 cents; per 5 , $\$ 1.25$.

BLACK ELDER (Sambucus Canadensis)-This is a native in the southeast corner of the state and in the Black Hills; a strong grower, stalk has a large pith; has large flat clusters of fragrant flowers in the spring, and small, purplish black berries in autumn; very much relished by some for pies, jelly, etc. It is beautiful, hardy and desirable. Each, 25 cents; per $5, \$ 1.00$.

SPEER ELDER-This is a large fruited variety found by $R$. $P$. Speer near Cedar Falls, Iowa. It is a large spreading bush with handsome foliage, but it is not quite so hardy as our native. However, we think it is desirable. 3 to 4 feet, 35 cents.

VARIEGATED OR GOLDEN ELDER (Sambucus Variegata)-A hardy, strong growing shrub of striking appearance, with light colored variegated foliage; snow white blossoms in clusters in early summer. This variety is sterile, however, and does not produce fruit. Each, 25 eents.

NEW CUT LEAVED ELDER-A variety with very handsome and striking foliage, and would be worthy of cultivation for its foliage alone, without any of its other strong points; quite productive. Strong, stocky plants, each, 30 cents; per $5, \$ 1.25$.

SUMACH (Rhus Trilobata)-A low, or medium sized shrub; native in this state. It is perfectly hardy, and its clusters of small red fruit with its bright colored foliage in the autumn, makes it quite desirahle. Each. 20 cents.

SUMACH (Cut Leaved Stag Horn)-This is a very beautiful, hardy, strong growing variety of this species with delicately cut massive leaves. A novelty and very desirable. 3 to 4 feet, each, 40 cents.

Take Notice that our shrubs are all strong, stocky, outdoor grown, and should not be classed with the small slender green-house plants offered by some at low prices.

\section{ORNAMENTAL CLIMBING VINES}

BITTERSWEET (Celastrus Scandens)-A hardy, native climber; has yellow flowers in summer, followed by orange-colored berries in autumn, which open late in the fall and expose the showy red fruits or seeds, similar to those of the Wahoo. Very pretty and easily grown. Each, 25 cents: per 5, $\$ 1.00$.

CLEMATIS (Flamuli)-A very desirnble climber. It is a rank grower and a profuse blooner; flowers s'ilall, gruenish-white; a hardy native. Each, 25 cents; 5 for $\$ 1.00$.

CLEMATIS (Coccinea)-A very in? anme, hardy climber; bearing thick, bell-shaped flowers of a hriglit, cor $\cdots$, red color; blooms with wonderful profusion from June till frost. Each, 30 cents.

CLEMATIS (Jackmanii)-Large flower, 4 to 6 inches in diameter: intense violet purple, with a rich velvety appearance. It blooms continually until cut by frost. A strong grower, but needs winter protectinn. Each, 40 cents.

CLEMATIS (Paniculata)-A sweet-scented, Japan Clematis; of very rapid growth. Unlike any other Clematis it has a beautiful, dense and glossy foliage, quickly covering trellinfs and arbors. The flowers are of medium size, pure white and of a most pleasing frasrance; borne in immense sheets in September, when very few other vines are in bloom. Each, 40 cents.

CLEMATIS (Mad. Ed Andre)-This is a bright red Clematis and has been called the Crimson Jackmanii. The plant is a strong, vigorous grower and a very free bloomer. A very pleasing shade and entirely distinct from all other varieties. Each, 40 cents.

CINNAMON VINES - Beautiful leaves, dainty flowers, exquisite perfume. The Cinnamon Vine, from the Oriental land, is one of the most charming of climbers and will quickly surround your window or veranda with a wonderful profusion of vines covered with handsome, glossy, heart-shaped leaves and sweet-scented flowers. Perfectly hardy, thriving everywhere, and once planted will grow for many years and be a source of constant delight. Each, 15 cents; 2 for 25 cents.

VIRGINTA CREEPER, AMERICAN IVY (Ampelopsis Quinquefolia) -One of the most vigorous and hardy climbers; the foliage becomes a rich crimson in autumn; very desirable for walls, verandas, etc. Each, 25 cents; per $5, \$ 1.00$.

BOSTON IVY (Ampelopsis Veitchii)-A very beautiful tenacious climber, clinging to the smoothest walls. The folia is a fresh deep green in summer changing to beautiful crimson and yellow shades in autumn. Not quite so hardy as Quinquefolia. Each, 30 cents. 
HONEYSUCKLE (Trumpet) - A very beautiful, hardy climber, with delicate trumpet-shaped red flowers; blooms constantly from early summer until hard frosts in fall; desirable. Each, 25 cents; 5 for $\$ 1.00$.

HALL'S HONEYSUCKLE (Lonicera Halleana)-One of the finest honeysuckles grown; blooms from June till November; is almost evergreen and is one of the most fragrant. White, changing to yellow. It is quite hardy here, and promises to be very valuable. Each, 30 cents; per $5, \$ 1.25$

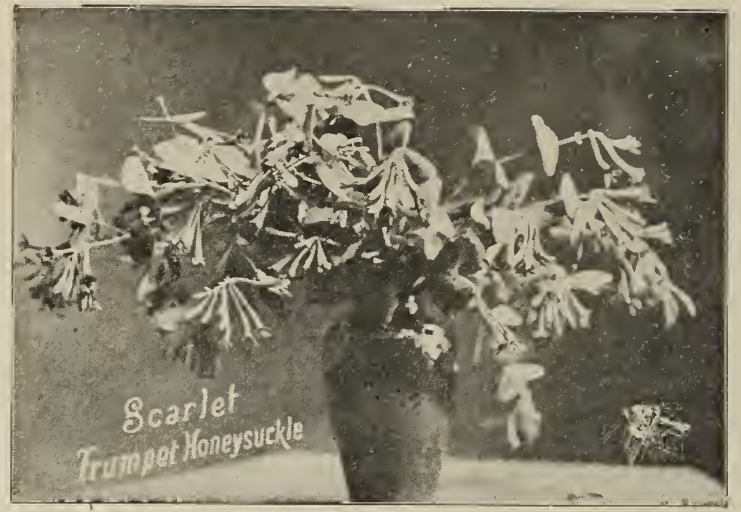

NATIVE WILD GRAPE-Seedlings. They are extremely hardy, and will be valuable to grow for screens and bowers, being a rank and rapid grower. Although its fruit is not of special value for eating, it makes a delicious jelly. Strong, 2 year plants, each, 20 cents; per 5. 75 cents.

WISTARIA, FRUTTICENS-A fine American trailing shrub, valuable in oranmental work. Flowers are a pale blue and borne in short clusters. A free bloomer and fragrant, hardy. Each, 30 cents.

WISTARIA, PURPLE-A most beautiful climber of rapid growth producing pendulous clusters of fine purple flowers; quite hardy. Each,

\section{BULBS}

\section{HERBACEOUS PAEONIES}

This is one of the most useful classes in the entire list. All hardy and showy.

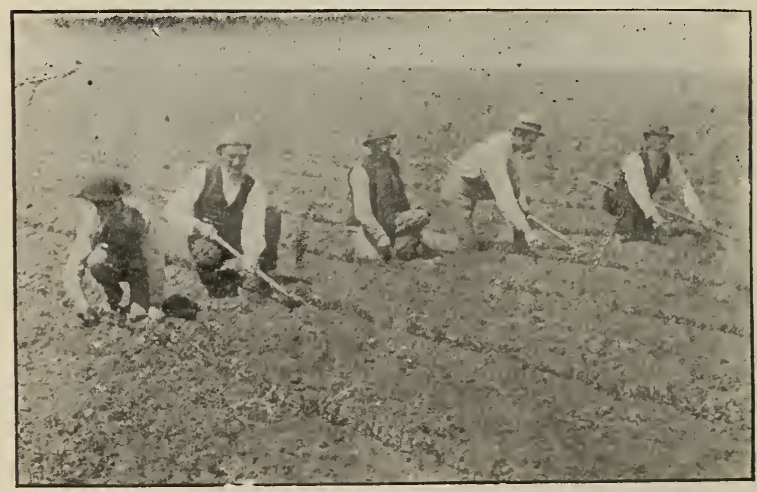

Weeding Small Plants

COMMON WHITE-This is an early, unnamed variety, and for a real good thing at a low price, I have nothing that will beat it. It is strong and vigorous in growth. Large, double flowers of a light pink tint with usually an orange-colored center, all changing to nearly a pure white after being open a few days. I offer this at the low price of 20 cents each, or 6 for $\$ 1.00$.

ROSE-A rose color, changing to a light rose soon after opening; large size and very double; slightly fragrant; a good grower. Each, 25 cents.

VARIEGATED-A vigorous grower of good size and quite double; color a light pink streaked with dark pink. Each, 25 cents. 


\section{NAMED VARIETIES PAEONIES}

HUNIEI-Blooms very large, often fully 6 inches in diameter; color is a bright pink with white tips, and somewhat streaked and variegated throughout. A perfect gem; very thick and double; slightly fragrant. Each, 40 cents.

FRAGRANS-Medium to large sized bloom. Very double and conical in shape; strongly rose-scented; very desirable. Price, strong roots, 40 cents each.

DARK CRLISON-The bloom is of medium size; semi-double; a dark, crimson color with yellow stamens showing prominently in the center; slightly scented; season, early. Price, each, 40 cents.

GARDNER'S RED-A very deep pink or red, with whitish tips, resembling Humei some, but is larger, and usually has several good blooms in a cluster; slightly rose-scented; a very fine showy and desirable sort; season, medium. Price, each, 50 cents.

DELACLI-A very dark, deep red, with very prominent yollow petals or stamens; large size. It is decidedly the most attractive one we have on the list. Price, each, 50 cents.

POTSI-A medium to large white, with a slight pink tinge in the center; a very strong grower and desirable; medium early. Price, each, 40 cents.

\section{GLADIOLUS}

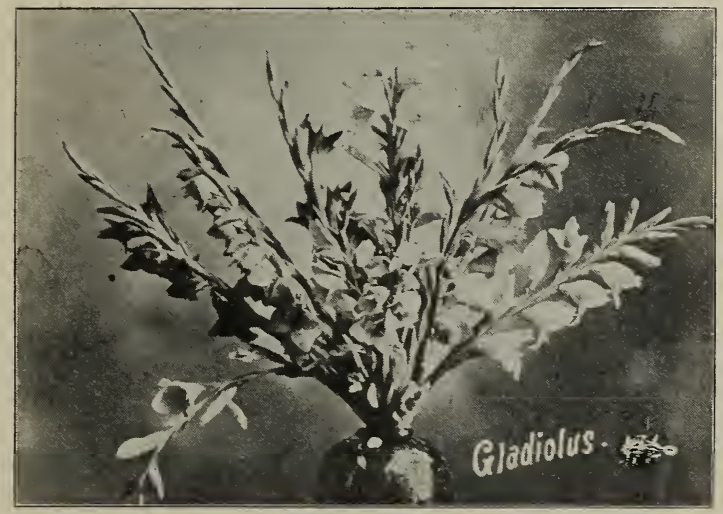

The Gladioli are the most attractive of all the summer flowering bulbs, and deserve a place in every garden, as they are sure to flower and do well with very little care. The flowers are of almost every desirable color. By cutting the spikes when two or three of the lower flowers are open, and placing them in water, the entire spike will open in the most beautiful manner. Set the bulbs 6 to 9 inches apart, and about 2 inches deep. Plant from middle of April to first of June. The bulbs must be taken up in the fall before the ground is frozen. and kept in a dry, cool cellar.

$\begin{array}{lrrrrr}\text { All large strong bulbs_ Each } & \text { Per } 5 & \text { Per } 10 & \text { Per } 50 & \text { Per } 100 \\ \text { Ass't colors in large variety } . \$ 0.05 & \$ 0.15 & \$ 0.25 & \$ 1.00 & \$ 1.75 \\ \text { Deep Red, all one color..... } .05 & .15 & .25 & 1.00 & 1.75 \\ \text { White, with pink stripes } \ldots . . & .05 & .15 & .25 & \ldots \ldots & \ldots .\end{array}$

\section{LILIES}

TIGER LILIES - These little lilies will thrive best in a dry, rich soil, where water will not stand in the winter. After planting they require very little care, and should not be disturbed for years, as established plants bloom more freely than if taken up annually; entirely hardy and very easily grown. We have both double and single flowering sorts; state which is desired. Bulbs, each 10 cents; 2 for 15 cents.

LILY OF THE VALLEY - Well-known. One of the most charming of the spring perennials. It loves a cool, shady, damp place. Each, 5 cents; 5 for 20 cents; 10 for 35 cents.

YUCCA (FILAMENTOSA) - It is popularly known as Bear's Thread or Adam's Needle; is an ornamental evergreen perennial plant having a cluster of lance linear sword-shaped leaves which are regular, serrated, and edged with slender threads, which hang down some three or four inches. The flowers are produced during the months of June and July, and are borne on flower-scapes or terminal panicles, which attain a height of 5 or 6 feet. 
We have counted 247 flowers on one stalk on our grounds. The are cup-shaped, pendulous and about $1 \frac{1 / 2}{2}$ inches in diameter, of a creamy white. It remains in bloorn two or three weeks. Its foliage is of the richest green during the autumn and winter months, when all other flowering and foliage plants have died away and left no trace of their summer beauty. Entirely hardy here, although it is not claimed to go as far north as the native variety listed below. Each, 30 cents; 2 for 50 cents.

YUCCA (GLAUCA), INDIAN SOAP PLANT-A native along the Missouri River bluffs. The description given above for the Filamentosa will apply quite well for this. The native, however, is perfectly hardy in high, dry, exposed locations; its leaf is longer, narrower, thicker, stiffer and more pointed and more of a whitish shade of green. Each, 25 cents; 2 for 40 cents.

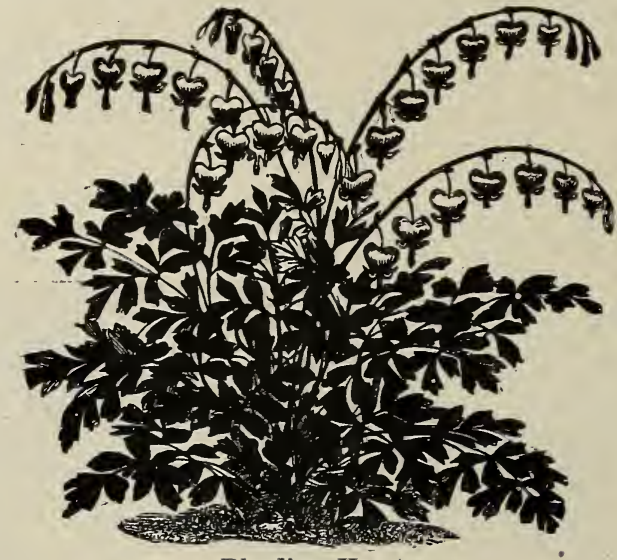

Bleeding Heart

BLEEDING HEART (Dicentrą Spectabilis)-A hardy perennial plant, producing long racemes of beautiful pink, heart-shaped flowers in May and June; an excellent border plant. Strong roots, each, 25 cts.

\section{IRIS}

These are a very desirable class of hardy, attractive border plants of the easiest culture. We have a variety of colors. The most important are as follows: The Bronze, Yellow and Blue, all large flowered sorts, and we also have the small Blue. They are all strong growers and easiy managed.

Each, 10 cents; per 5,35 cents; per 10,50 cents.

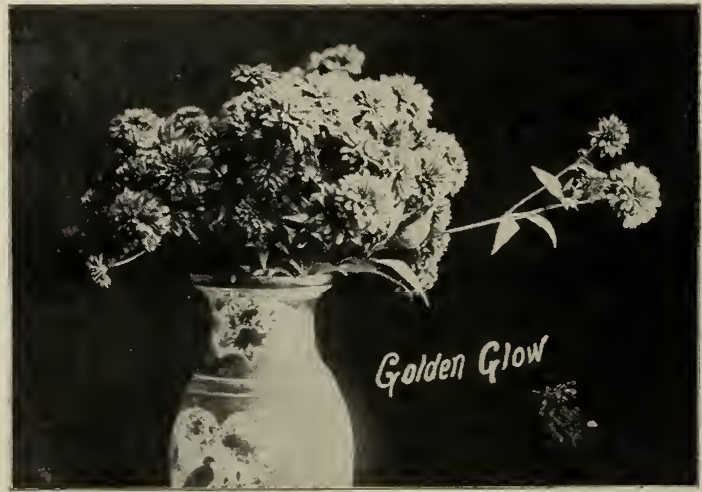

GOLDEN GLOW (Rudbeckia) - This new American plant is winning great favor wherever introduced. A hardy perennial, growing 6 to 7 feet high, and producing hundreds of bright golden double flowers 2 to 3 inches in diameter; fine for cut flowers. When once established, will produce an endless amount of blooms. Can be grown with very little care almost anywhere. Each, 15 cents; 2 for 25 cents. 


\section{DAHLIAS}

A very attractive flower, which blooms late in the summer. There are a great variety of sorts, of as many colors and forms of bloom. Dahlia roots must be taken un in the fall before the ground freezes and kept in a cool, dry cellar, away from frost, similar to potatoes. Plant out in the spring in rich, mellow soil. They are rery desirable and easily grown. We have the Pink, Yellow and Maroon. State color desired.

Price, each, 10 cents; 4 for 25 cents; 10 for 50 cents.

\section{Roses}

Plant in a situation where plants will receive plenty of sunshine. Make the soil rich with well rotted manure and work it deep. All roses should be laid down in the fall, and covered with dirt or coarse litter to secure best results.

Prune out the old dead wood every year, and keep the bush vigorous and thrifty; it will increase the blooming. All roses listed herein are strong 2-year field-grown plants.

\section{JUNE ROSES}

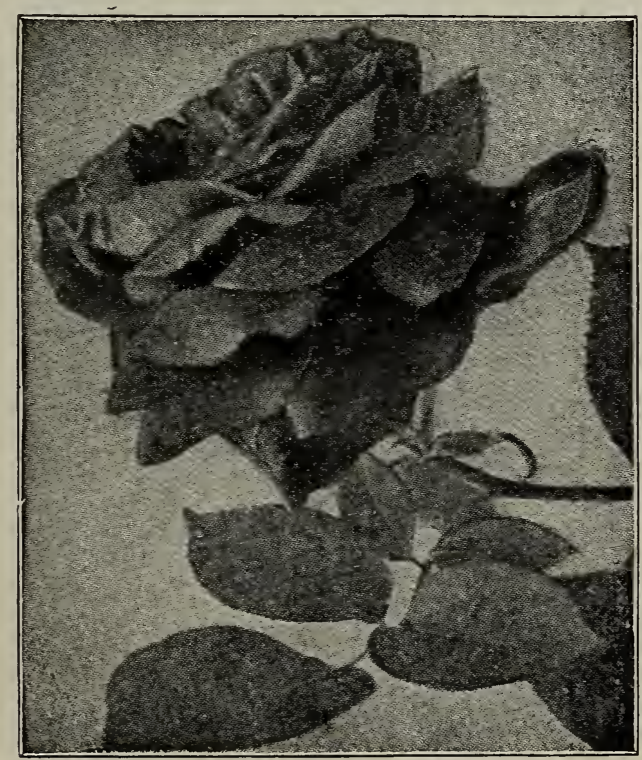

American Beauty

CINNAMON-A strong grower and perfectly hardy. Bloom is small pink, and somewhat ragged, but it is the earliest in our list, and will be appreciated on that account, if for no other. Each, 20 cents.

BLCSH-A large and very double rose; color, a pale pink, almost white. Blooms very profusely; it is a very strong, rank grower, and is the hardiest rose in our list. Each, 20 cents.

PERSIAN YELLOW-Hardy; flowers double and full, deep golden yellow in color; blooms freely in June. The finest hardy yellow rose grown. Each, 25 cents.

ROSA RUGOSA-Foliage shiny bright green; flowers deep rose, single, produced in clusters. Beautiful bright red berries in autumn. Very hardy and desirable. The Rugosa makes a fine border or hedge and we offer them in quantity for this purpose; try them, they are very satisfactory. Each, 25 cents; per 10, $\$ 2.00$; per 50, $\$ 7.00$; per $100, \$ 12.00$. 


\section{HYBRID PERPETUAL ROSES}

AMERICAN BEAUTY-A strong, vigorous grower, a continuous bloomer, and the flowers are very large and of a deep rose color; delightfully fragrant; a general favorite. Each, 25 cents.

MADAME PLANTIER-Pure white, an excellent rose and a free bloomer; very hardy. Madame Plantier is known by many as the Century Rose. It is a beautiful rose for the cemetery, as it bears a profusion of pure white blossoms and is hardy. Each, 25 cents.

GENERAL JACQUEMINOT-Brilliant crimson; not full, but very large and effective; a mass of bloom when at its best; very fragrant; quite hardy. Each, 25 cents.

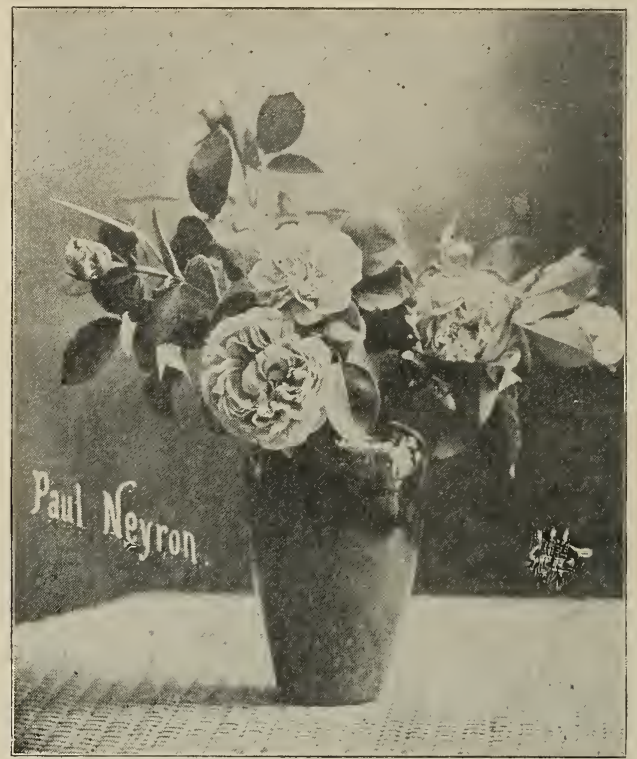

PAUL NEYRON-Flowers of immense size, color deep, clear rose; very fresh and pretty; the plant is a strong, healthy grower with clear glossy foliage; a most prolific bloomer. Blooms from June to October almost constantly. Each, 25 cents.

ULRICH BRUNNER-Splendid upright grower, with bright, healthy foliage. The flowers are good-sized and of fine form, with shell-shaped petals. One of the most abundant bloomers; color, cherry red. Each, 25 cents.

\section{MOSS ROSES}

GLORY OF MOSES-Pale rose color; very large and flat in form; robust and vigorous; very handsome and desirable. Each, 25 cents.

PERPETUAL WHITE-Pure white; blooms in clusters, vigorous grower and hardy; very handsome and remains in bloom a long time. Each, 25 cents.

PERPETUAL RED-Similar to Perpetual White, except in color. It is fully as desirable and should be in every collection of moss roses. Each, 25 cents.

PRINCESS ADELAIDE-Blush, becoming quite pale or white; very double and well formed; the most vigorous grower of all the mosses. Each, 25 cents.

\section{CREEPING ROSES}

The Japanese creeping rose, Wichuriana, is one of the most beautiful and useful plants for cemetery or lawn planting. As hardy as an oak, and grows on any sandy sidehill or other exposed place where but few plants succeed. Flourishes if allowed to trail over the ground in its natural position, or may be trained to posts or trellises.

MANDA'S TRIUMPH-This is a grand variety. The flowers, which are pure white, and very double, are produced in clusters of from 10 to 12 on each cluster on small side shoots, literally covering the plant and standing well above the foliage. Each, 25 cents.

PINK ROAMER-A hybrid of the Sweet Briar, which it somewhat resembles in character of bloom, while the growth, which is very rampant, partakes more of the Wichuriana type. The single flowers are over 2 inches in diameter, a bright, rich pink, with large, silvery white center and orange red stamens. 'Each, 25 cents. 


\section{RAMBLER ROSES}

CRIMSON RAMBLER-Perfectly hardy, wonderful free flowering, rich, glowing crimson; a color unheard of before in hardy climbing roses. The plant is a strong, rampant grower, making shoots 8 to 12 feet long in a season after the first year, or when well established. The flowers are produced in large trusses, pyramidal in shape, often 25 to 30 in a cluster, fairly covering the plants from the ground to the top with a mass of bright, glowing crimson. The color is simply superb, and is retained unfaded for an unusual length of time. Each, 30 cents.

YELLOW RAMBLER (Agalia)-A new hardy yellow climbing rose, blooming after the same manner as Crimson Rambler; flowers of medium size in immense clusters, often 35 to 40 rlowers in a single cluster; very sweet-scented. Color a clear, decided yellow, a color heretofore unknown in a climbing rose that was in any way hardy. It is a rampant grower. Each, 30 cents.

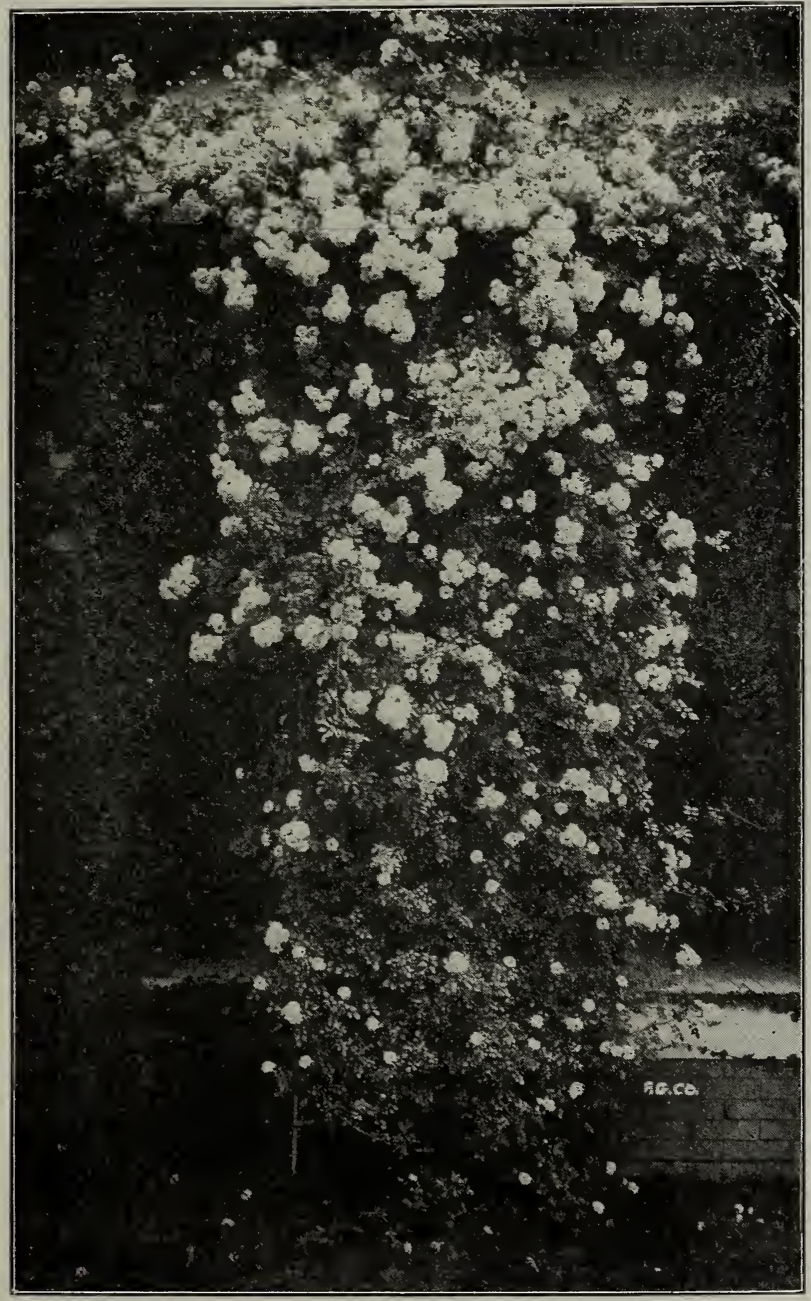

\section{Yellow Rambler}

PINK RAMBLER-This is a strong grower and one of the grandest bloomers in the list. Of a most beautiful pink and is becoming very popular. Each, 30 cents.

WHITE RAMBLER-Similar to the other Ramblers, but it is a pure pearl white in color. Each, 30 cents.

DOROTHY PERKINs - In general habit it resembles the Crimson Rambler, but of a beautiful shell pink, full and double; of unusually large size for a cluster rose. The trusses are made up of from 30 to 40 or more flowers. A very valuable acquisition. Each, 30 cents. 
BABY RAMBLER-An offspring of the famous Crimson Rambler. It does not climb, however, but bushes nicely and also submits to pot culture. Will bloom continuously throughout the summer if planted out of doors; it sometimes blooms the first year after planting. Has the same bright crimson color as the Crimson. Rambler and blooms in clusters of 20 to 40 flowers at one time. A' great novelty and a valuable acquisition; has recently been sold for $\$ 1.00$ each, but I have grown a nice stock of them the past season and am able to offer strong, 2 year, field grown plants, at 50 cents each.

\section{CLIMBING ROSES}

Nothing can cover an arbor or veranda, or form a beautiful screen for an unsightly object so charmingly as a climbing rose. Annual growths require ten-fold the care in yearly training and renewing; the climbing rose needs but one planting and increases in beauty as the years go by.

BALTMMORE BELLE-Pale blush, shading to rose color; very double; flowers in beautiful clusters, the whole plant appearing a perfect mass of bloom. One of the best climbing roses, but must be protected in winter. Each, 25 cents.

GREVILLE (or Seven Sisters)-Blooms in large clusters, with flowers varying from white to crimson; luxuriant dark green foliage; perfectly hardy. Each 25 cents.

PRAIRIE QUEEN-Clear, bright, crimson pink, sometimes with a white stripe; large, compact and globular, double and full; blooms in clusters; the best hardy climber in this climate. Each, 25 cents.

Please note the cash discounts offered on large orders on second cover page.

\section{Read This}

We are enabled to make the low prices contained in this catalogue for strictly first-class stock because we have adopted a strictly cash system. No one can afford to give the same prices on a credit basis that they can for cash. We intend to use everyone alike as near as we can under like circumstances, and no matter what you are worth or what your.standing, please understand that I have adopted this rule-cash before shipment in every case, and cannot deviate from it.

Please note that I make a fair, reasonable price on everything; we do not promise you something for nothing; we give no premiums, but make reductions on large quantities and give a graduated discount according to size of order. See inside of front cover.

If you do not find listed such stock as you want, write us.

Notice that we list all trees by size or age, so that you know what you are buying.

Yours very respectfully,

GEORGE H. WHITING.

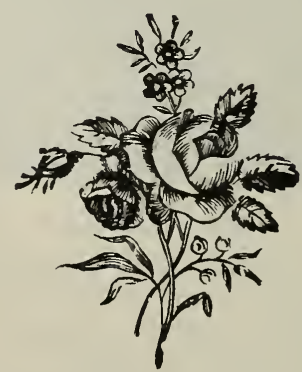




\begin{tabular}{|c|c|}
\hline Page & Name \\
\hline pricots & Introductory \\
\hline Apples (Standard) $\ldots \ldots \ldots$. 4 -7 & Iris $\ldots \ldots \ldots$ \\
\hline Apples (Hybrid) $\ldots \ldots \ldots \ldots \ldots 6-7$ & $\ldots .2 d$ cover \\
\hline Apples (Prices) $\quad \ldots \ldots \ldots \ldots \ldots 7$ & June-berries $\quad \ldots \ldots \ldots \ldots \ldots \ldots 11$ \\
\hline Asparagus $\quad \ldots \ldots \ldots \ldots \ldots \ldots \ldots$ & Junipers $\ldots \ldots \ldots \ldots \ldots \ldots 2$ \\
\hline After Care $\ldots \ldots \ldots \ldots \ldots \ldots \ldots \ldots$ & June Roses ............. \\
\hline Buffaloberry $\ldots \ldots \ldots \ldots \ldots \ldots 11$ & Location of Orchard $\ldots \ldots \ldots \ldots 4$ \\
\hline$\ldots \ldots \ldots \ldots 13$ & Lilacs $\ldots \ldots \ldots \ldots \ldots \ldots$ \\
\hline$\ldots \ldots \ldots \ldots \ldots$ & Lilies $\ldots \ldots \ldots \ldots \ldots \ldots \ldots$ \\
\hline$\ldots \ldots \ldots \ldots 9-10$ & Miscellaneous Shrubs .... \\
\hline Choke Cherries ........ & Moss Roses $\ldots \ldots \ldots \ldots \ldots \ldots \ldots 40$ \\
\hline Compass Cherry $\ldots \ldots \ldots \ldots 10$ & No. of trees to the acre.......4 \\
\hline Currants $\ldots \ldots \ldots \ldots \ldots \ldots \ldots \ldots \ldots \ldots \ldots \ldots$ & Named Varieties Paeonies \\
\hline Cuttings $\ldots \ldots \ldots \ldots \ldots \ldots \ldots \ldots 17$ & No Credit \\
\hline Creeping Roses ............40 & Ornamental Shrubs $\ldots \ldots \ldots$ \\
\hline Climbing Roses $\ldots \ldots \ldots \ldots \ldots 42$ & Ornamental Climbing Vines....35 \\
\hline Distances apart to plant.......4 & Our Method with Evergreens...34 \\
\hline Dist. apart, apple trees. & Planting $\quad \ldots \ldots \ldots \ldots \ldots \ldots \ldots \ldots$ \\
\hline Dwarf Juneberry ..... & Pears $\ldots \ldots \ldots \ldots \ldots \ldots \ldots$ \\
\hline Dewberries.$\ldots \ldots \ldots$ & Plums $\quad \ldots \ldots \ldots \ldots \ldots \ldots$ \\
\hline Deciduous Shade and Or- & Pieplant $\quad \ldots \ldots \ldots \ldots \ldots \ldots$ \\
\hline ental trees $\ldots \ldots \ldots \ldots$ 1s & 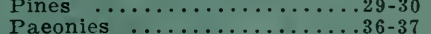 \\
\hline Dahlias $\ldots \ldots \ldots \ldots \ldots \ldots$ & nies $\ldots \ldots \ldots \ldots \ldots \ldots \ldots$ \\
\hline Discounts ...........2d cover & Pruning Knives $\ldots \ldots \ldots \ldots . \ldots$ \\
\hline$\ldots \ldots \ldots 2 ?$ & Pruning Shears $\ldots \ldots \ldots . . .3 d$ \\
\hline European Larch $\ldots \ldots \ldots \ldots . . .31$ & Raspberries $\ldots \ldots \ldots \ldots \ldots$ \\
\hline Ento. Certificate .......3d cover & Rhubarb $\ldots \ldots \ldots \ldots \ldots$ \\
\hline Exposition Diploma ........ 2 & $\ldots \ldots \ldots \ldots \ldots$ \\
\hline Fruit Department $\ldots \ldots \ldots \ldots$ 4-14 & Rambler Roses \\
\hline Form of Tree $\ldots \ldots \ldots \ldots$ & Read This (remarks) .... \\
\hline Fall Apples ... & Summer Apples $\ldots \ldots \ldots \ldots$ \\
\hline Forestry Department & Sand Cherries $\ldots \ldots \ldots \ldots$ \\
\hline Forest Seedlings (Prices) & Strawberries \\
\hline General Remarks ...... & Sending Stock by Mail... \\
\hline$\because \ldots \ldots \ldots \ldots$ & Seedlings for $\mathrm{Hedzes} . . .$. \\
\hline Gooseberries $\ldots \ldots \ldots \ldots \ldots \ldots \ldots$ & 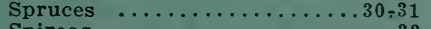 \\
\hline Gladiolus & $\ldots \ldots \ldots \ldots$ \\
\hline Golden Gluw & Sending Orders .... \\
\hline Hints, planting, etc. & Shipping Location ... \\
\hline How apple trees are $\mathrm{m}$ & Tree Seeds \\
\hline Hybrid Apples ........ & Varieties \\
\hline Hedge Seedlings $\ldots \ldots$. & Windbreaks for Orchards \\
\hline $\begin{array}{l}\text { Honeysuckles } \\
\text { Herbaceas } \mathrm{P}\end{array}$ & Winter Apples $\ldots \ldots \ldots \ldots$ \\
\hline eas & Weeping Trees \\
\hline
\end{tabular}

\title{
PRUNERS.
}

CALIFORNIA PRUNING SHEAR-This is one of the best shears made. Total length, 9 inches. Indestructible steel spring; will stand more rough usage and outlast any shear we have used. One pair is worth two pair of the ordinary cheap ones. Price by mail, prepaid$\$ 1.00$ each; not prepaid, 85 cents.

PRCNING KNTFE-A good, strong, durable knife; strong hooked blade. made of best steel. with brown wooden handle, and made to close like an ordinary pocket-knife. For trimming it is enough better than an ordinary knife to pay for itself in two days' work. Makes a smoother cut than the shears. Price, by mail, prepaid, 75 cents each; not prepaid. 65 cents.

\section{ENTOMOLOGIST'S CERTIFICATE}

\section{THE SOUTH DAKOTA AGRICULTURAL COLLEGE}

\section{CRRTIFICATE OF INSPECTION}

\author{
Brookings, S. D.
}

To Whom It May Concern:

Brookings, S. D., Sept. 11th, 1906 .

This Is to Certify, that on the first day of September, 1906 I examined the Nursery Stock growing on the grounds of the Whiting Nurseries, Geo. H. Whiting, proprietor, Yankton, S. D. and found no indication of the presence of San Jose scale or other dangerous insect or plant diseases. The stock inspected consisted of Fruit. Forest and Shade Trees and Small Fruit and Ornamental Plants, occupying about 75 acres of ground.

This Certificate, unless revoked, is good for one year from date of inspection.

W. A. WHEELER, State Entomologist. 



\section{Half Price Cupon}
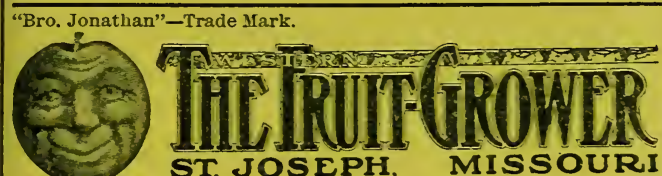

The Fruit-Grower is the only magazine in Americ: which is devoted exclusivels to the interests of those who grow fruit. It is handsomels illustrated, and contains from 36 to 76 pages each month. It tells all about fruit of all kinds-and nothing but fruit-how to market, liow to yack, cultirate, spras, prune, how to MAKE MORE MONEI from your crops. Sample copy will be sent free. Regular nrice is a dollar a rear, but by special arrangement with the firm named at foot of this page, we will send Tile Fruit-Grower to TTO NAMES one vear for a dollar, if rou use this COLPON, and in addition will mail to each a choice of any one of our ten Brother Jonathan books. described on other side. If after reading six issues rou are not satisfied with rour investment, we will return sour moner. One of the two names sent with this coupon must be a NEW SUBSCRIBER. Ask one of rour neighbors or friends to join you and REMIT DIRECT TO

THE FRUIT-GROWER C0., St.Joseph, Mo.

THE FRUIT-GRONTER CO. St. Joseph. Mo

Inclosed find renittarce of ONE DOLLAR for which Inclosed find remirtand books according to sour special offer, to the names written below.

Name

P. O. Box or Route No

Send Book No.

State

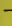

Name

P. O. Box or Route No.

Send Book No...........

Town

\section{To Our Friends and Patrons:}

The recommend that rou take adrantage of The FruitGrower's Special Offer. While the regular price is one dollar, we hare arranged with the publishers so rou may secure the paper at HALF PRICE and in addition rou get one of their valuable books FREE. A single issue of The Fruit-Grower is worth a dollar to one who grows fruit, and the books are the vers best of the kind in existence The Fruit-Grower Co. guarantees to RETURN YOUR today with this coupon and rou will never regret it.

GEO. H. WHITING. Yankton, S. D.

Fram

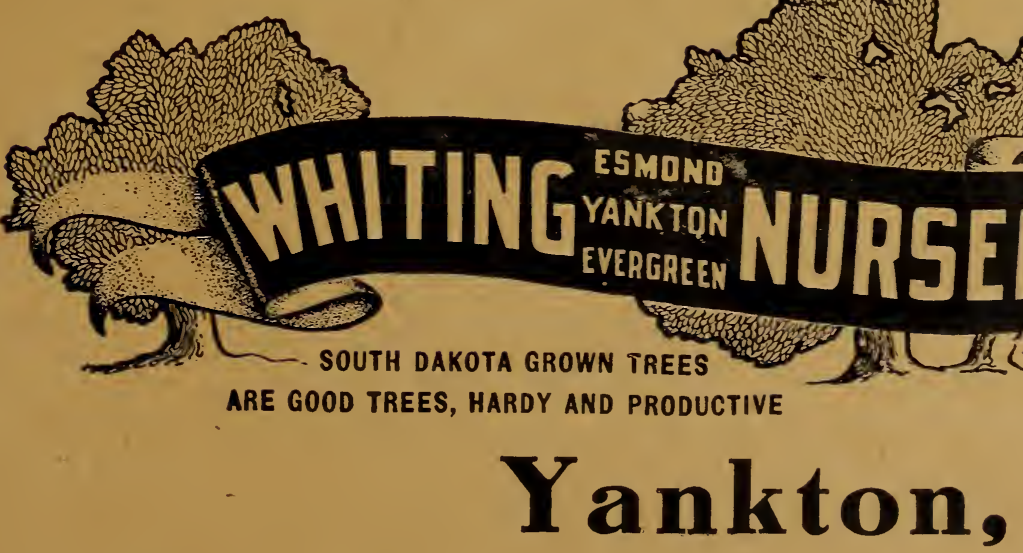

So. Dak. 


\section{"Bro. Jonathan" Fruit Books}

Copyrighted by The Fruit-Grower Co., st. Foseph, Missouri

This is a series of booklets published exclusively by The Fruit-Grower Co., St. Joseph, Mo., on different phases of fruit growing, which are intended to help those engaged in horticulture. All books are nicely illustrated.

No. 1-"Propagating Trees and Plants."

Describes the process of budding, grafting. lavering, etc. By Prof. W. L. Howard, of the University of Missouri, with photographs by Mr. E. H. Favor.

Tio. 2-"A Treatise on Spraying."

By Prof. J. M. Stedman, entomologist of the Missouri Experiment Station. Many destructive insects are shown, with full directions for combating them.

No. 3- "How to Grow Strawberries."

By Dr. J. C. - Whitten, professor of borticulture of the University of Missouri. It treats of growing strawberries as a commercial crop or for home use.

No. 4- "The Home Garden."

By Prof. Howard and Mr. Favor. It tells how to make hotheds, coldframes, etc.; how to handle them to the best advantage. All about vegetables.

To. 5-"Packing and Marketing Fruits."

By Prof. F. A. Waugh. This book tells about the correct time for picking different fruits, describes different packages used in which to market tbem.

N0. 6-"A Book About Bush Fruits."

By Prof. A. T. Erwin of Iowa Agricultural College. culture; gives recipes for canning and preserving.

Treats of blackberries, raspberries, etc., with methods of No. 7-“Growing Grapes."

By E. H. Riehl, Alton, Ill. Mr. Riehl is a successful commercial grower, and discusses varieties, modes of training, etc. Every grape grower should have it.

T10. 8- "Hints on Pruning."

By Dr. J. C. Whitten. The pruning of different kinds of fruit trees and plants is discussed, with reasons for the methods recommended.

No. 9- "Apple Culture with a Chapter on Pears."

By Dr. J. C. Whitten. This is intended to be a booklet for the practical man who wants to know how to get some profit from his orchard.

No. 10-"Success with Stone Fruits."

By Prof. F. A. Waugh. The different stone fruits are treated, with lists of best varieties of each. Methods of planting, pruning, etc., are discussed.

THESE BOOKLETS WILL BE SENT POSTPAID FOR $25 \mathrm{c}$ Each or FIVE for One Dollar

Read the SPECIAL OFFER on other side, whereby two of these books will be sent FREE upon receipt of remittance of ONE DOLLAR for TWO yearly subscriptionsHALF PRICE. The Department of Agriculture of British Columbia ordered 7,500 of these books recently, showing that they are good enough to be appreciated in a section where fruit is raised scientifically.

We offer commission to agents and hundreds of dollars in Cash Prizes for securing new subscribers. Write for sample copies of The Fruit-Grower and particulars. Send a dollar and take advantage of our Special Offer. Write names on other side of this coupon and REMIT DIRECT TO THE FRUIT-GROWER C0., St. Joseph, Mo. 



\section{A Pleased Customer}

is the best advertisement that can be produced. Below we give a half-tone cut of the home of Alfred Terry, of Slayton, Minn., which was sent me unsolicited, together with the letter which follows. Many others of a similar character could be shown if necessary.

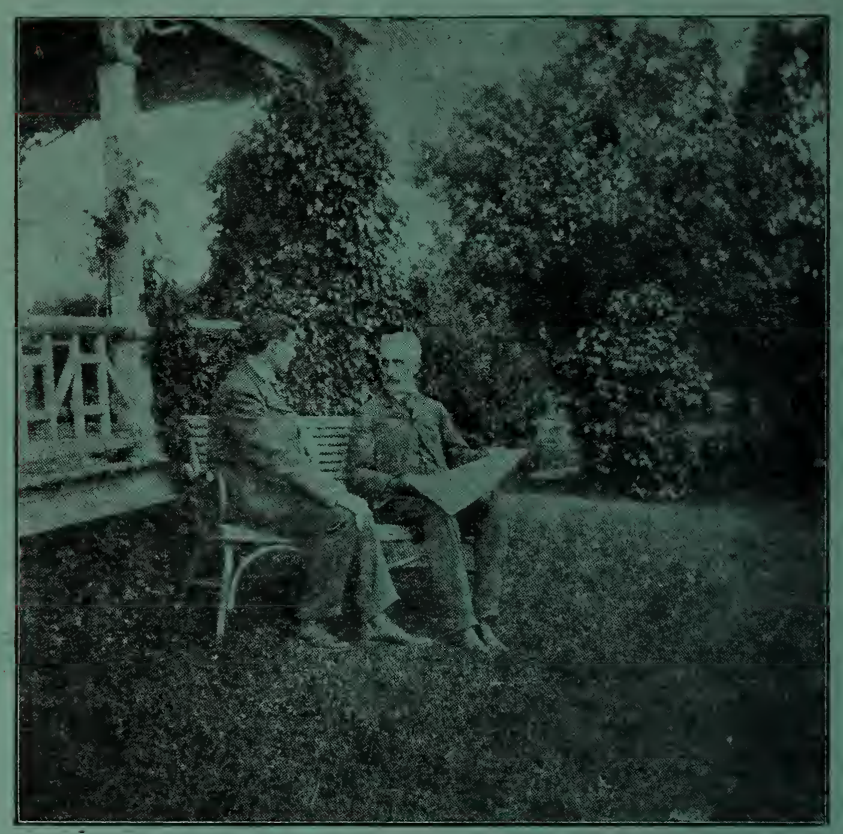

Mr. Terry and Son at Home

Reference: First National Bank, Slayton. ALFRED TERRY, Slayton, Minnesota.

Geo. H. Whiting, Esq., Yankton, S. D.

Dear Sir:-I was so pleased with your new catalogue, its get-up, its prices, and your evident success, that I ap constrained to write you my congratulations and to wish you many years of prosperity. I shall keep the catalogue in my office and recommend my friends to deal with you. It is a great many years since I began to buy of you, and my own 10-acre residence and many farms in Murray Co., as well as the lots and streets of this village, are beautified by stock from your nursery, and are living testimonials of the reliability of it.

Yours very truly,

ALFRED TERRY. 